\title{
WestVirginiaUniversity
}

THE RESEARCH REPOSITORY @ WVU

Graduate Theses, Dissertations, and Problem Reports

2003

\section{Regulation of P-glycoprotein and ABCP transporters}

Dhanashri Ramkrishna Kolwankar

West Virginia University

Follow this and additional works at: https://researchrepository.wvu.edu/etd

\section{Recommended Citation}

Kolwankar, Dhanashri Ramkrishna, "Regulation of P-glycoprotein and ABCP transporters" (2003).

Graduate Theses, Dissertations, and Problem Reports. 1828.

https://researchrepository.wvu.edu/etd/1828

This Dissertation is protected by copyright and/or related rights. It has been brought to you by the The Research Repository @ WVU with permission from the rights-holder(s). You are free to use this Dissertation in any way that is permitted by the copyright and related rights legislation that applies to your use. For other uses you must obtain permission from the rights-holder(s) directly, unless additional rights are indicated by a Creative Commons license in the record and/ or on the work itself. This Dissertation has been accepted for inclusion in WVU Graduate Theses, Dissertations, and Problem Reports collection by an authorized administrator of The Research Repository @ WVU.

For more information, please contact researchrepository@mail.wvu.edu. 


\title{
REGULATION OF P-GLYCOPROTEIN AND ABCP TRANSPORTERS
}

\author{
Dhanashri R. Kolwankar
}

\author{
A DISSERTATION \\ Submitted to \\ The School of Pharmacy \\ at \\ West Virginia University \\ in partial fulfillment of the requirements \\ for the degree of \\ DOCTOR OF PHILOSOPHY \\ in \\ Pharmaceutical Sciences
}

Committee:

Timothy S. Tracy, Ph.D., Chair

Patrick S. Callery, Ph.D.

Douglas D. Glover, M.D.

Yongyut Rojanasakul, Ph.D. Joseph A. Ware, Ph.D.

Department of Basic Pharmaceutical Sciences

Morgantown, WV

2003

Keywords: P-glycoprotein, multidrug resistance, cytochrome P450 1A1, placenta, smoking, Breast cancer resistance protein, cytochrome P450 3A4, induction.

Copyright 2003 Dhanashri R Kolwankar 


\section{ABSTRACT \\ REGULATION OF P-GLYCOPROTEIN AND ABCP TRANSPORTERS}

\section{Dhanashri R. Kolwankar}

The placenta plays an important role in modulating xenobiotic passage from mother to fetus. Smoking is known to induce cytochrome P450 1A1 (CYP1A1) expression in the placenta, however its effect on P-glycoprotein (P-gp) and $\mathrm{ABC}$ transporter in placenta $(\mathrm{ABCP})$ levels in placenta is not known. In-vitro studies in hepatocytes have reported induction of P-gp mRNA by some polycyclic aromatic hydrocarbons. To examine whether smoking can affect placental P-gp and ABCP, their expression and activity were determined in placentas from smokers and non-smokers. Uptake of $\left[{ }^{3} \mathrm{H}\right]$-vinblastine and $\left[{ }^{3} \mathrm{H}\right]$-mitoxantrone was used to measure $\mathrm{P}$-gp and $\mathrm{ABCP}$ function, respectively and CYP1A1 activity (positive control) was assessed using ethoxyresorufin O-deethylation as the model reaction. P-gp and ABCP expression was measured by immunoblotting. Uptake of $\left[{ }^{3} \mathrm{H}\right]$-vinblastine in vesicles was osmotically sensitive, suggesting intravesicular accumulation and was inhibited by verapamil, a P-gp inhibitor. Uptake of $\left[{ }^{3} \mathrm{H}\right]$-mitoxantrone was inhibited by fumitremorgin $\mathrm{C}$, an $\mathrm{ABCP}$ inhibitor but not by verapamil. Though CYP1A1 activity was significantly higher in smokers, no statistical difference $(P>0.05)$ was noted in P-gp and ABCP function or expression between smokers and non-smokers suggesting that smoking has no effect on placental P-gp and ABCP activity or expression.

In order to study the induction of P-gp, we used LS174T cells to screen for compounds for their ability to induce P-gp. As CYP3A4 and P-gp are coordinately upregulated, CYP3A activity was also assessed as the formation of 1'-hydroxy midazolam. Uptake of VBL was used to measure P-gp function and expression was measured by immunochemical methods. CYP3A activity was 4 times higher and P-gp activity was significantly higher after rifampin treatment. Rifampin treatment also produced an increase in protein abundance and surface expression of P-gp. To assess involvement of the Pregnane X Receptor (PXR) in P-gp induction, a set of multiple compounds with varying degrees of PXR activation were evaluated for effect on P-gp expression. PXR activation and P-gp expression were positively correlated, supporting the role of PXR in regulation of P-gp. These data suggest that LS174T cells have the potential to be used in studying the effect of inducers on CYP3A and P-gp simultaneously. 
Dedicated to Santy and Giri 


\section{ACKNOWLEDGEMENTS}

I would like to thank my academic and research advisor, Dr. Tim Tracy, who has been a great mentor and helped me develop as a scientist. I am grateful for his help and encouragement and feel extremely fortunate for having an opportunity to work with him. I would like to thank Drs. Patrick Callery, Yon Rojanasakul, Douglas Glover and Joe Ware for being on my dissertation committee and for providing useful suggestions, comments and constructive criticism. It was indeed a great privilege for me to work with researchers of such high caliber.

My summer internship at Pharmacia Corp. was immensely valuable for developing my skills and I thank all the people at Pharmacia who made it a fruitful experience.

I take this opportunity to thank all BPS faculty and also Penny Dailey and Blanche Rybeck for their help and support throughout my graduate program. I thank Dr. Xiangling Shi for facilitating the use of instruments and equipment at NIOSH.

I am highly indebted to my parents for their selfless love, affection and caring. Thank you, daddy and mummy, for believing in me and helping me believe in myself which was the most important factor that helped me get this far and enabled me to achieve my educational objectives. I am extremely fortunate to have such loving brother, Santosh and sister-in-law, Shefali who have been such good friends and always supported my decisions. I cannot thank enough, Giri, my best friend and husband, who has always been there for me. He has been a constant source of inspiration and support in all times. Finally, I would like to thank all my family and friends, for without them all this would not have been possible. 


\section{Table of Contents}

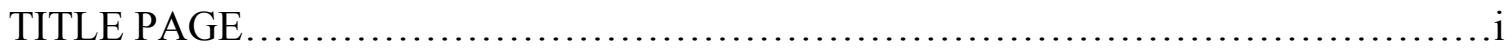

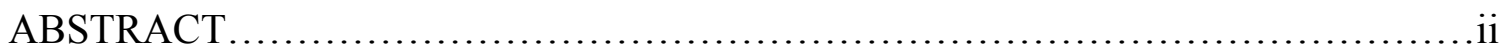

DEDICATION .................................................................

ACKNOWLEDGEMENTS......................................................

TABLE OF CONTENTS ......................................................

LIST OF FIGURES....................................................vii

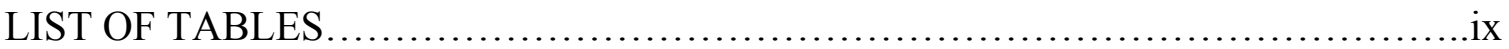

LIST OF TERMS AND ABBREVIATIONS................................................................

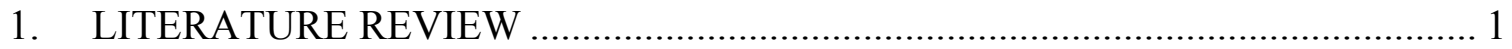

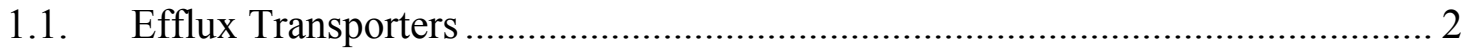

1.2. P-glycoprotein (P-gp) .......................................................................... 4

1.2.1. Tissue Distribution and Function of P-gp .......................................... 6

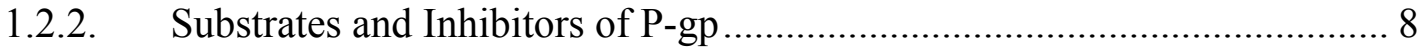

1.2.3. Induction, regulation and drug-drug interactions of P-gp........................ 9

1.2.4. Genetic Polymorphism in P-gp .............................................................. 11

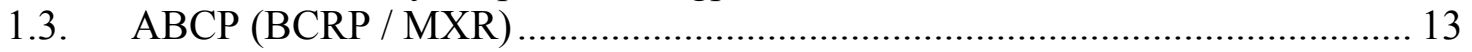

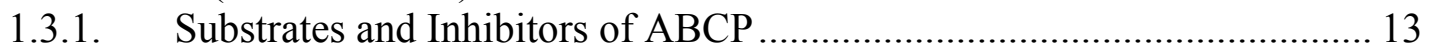

1.3.2. Tissue distribution, location and function of $\mathrm{ABCP}$............................... 16

1.3.3. Mutations / polymorphisms in ABCP .................................................... 17

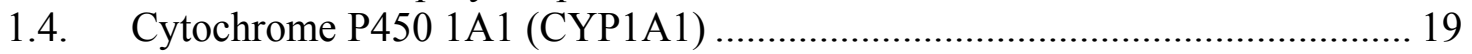

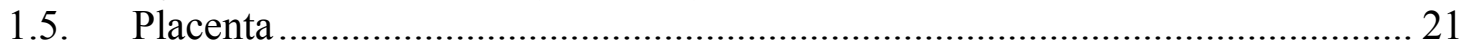

1.6. Effect of smoking on placenta and placental enzymes and transporters ......... 23

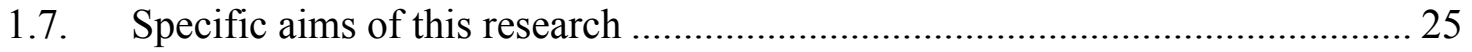

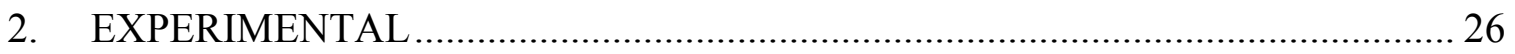

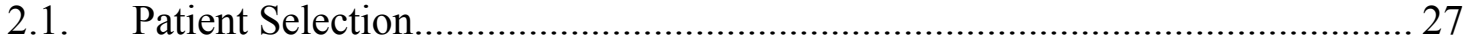

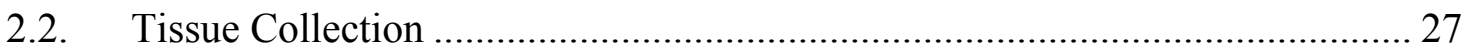

2.3. Preparation of Microvillus and Basal Membrane Vesicles.............................. 30

2.4. BCA Protein Assay ............................................................................... 31

2.5. Sialic Acid Assay for Sidedness or Orientation of Membrane Vesicles .......... 32

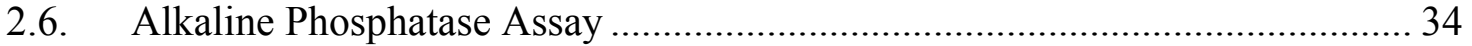

2.6.1. For determination of enrichment of the microvillus membrane ............... 34

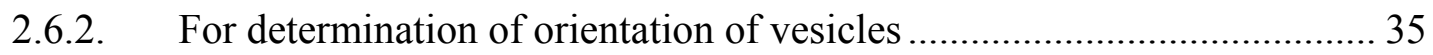

2.7. Uptake Assay: Developmental Work and Final Protocol .............................. 36

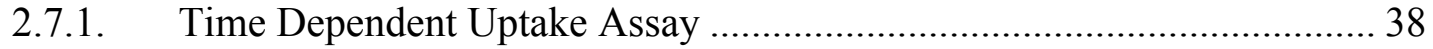

2.7.2. Osmotic Dependent Uptake Assay ...................................................... 38 
2.7.3. Determination of type of filters and filter soaking media to block the nonspecific binding..... 38

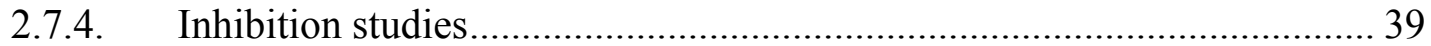

2.8. Immunoblotting Studies for Detection of P-gp and ABCP ............................ 39

2.9. Preparation of Placental Microsomes …………......................................... 42

2.10. Ethoxyresorufin- $O$-deethylation Assay for CYP1A1 ……............................... 43

2.11. Cell Culture ............................................................................................ 45

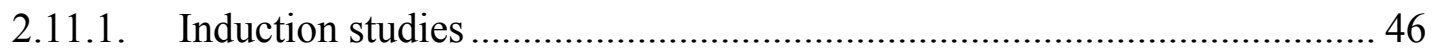

3. EVALUATION OF P-GLYCOPROTEIN AND ABCP EXPRESSION AND FUNCTION IN HUMAN PLACENTAL TISSUE FROM SMOKERS AND NON-

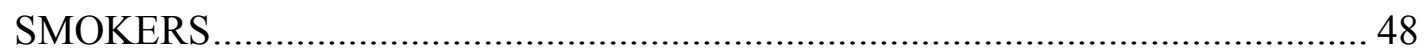

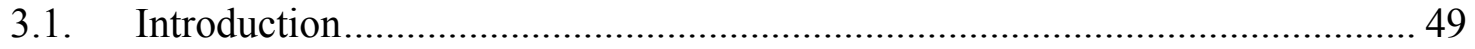

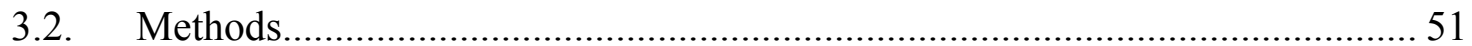

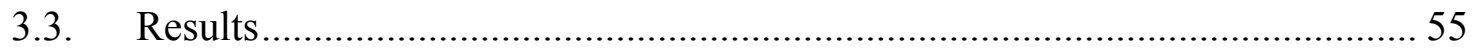

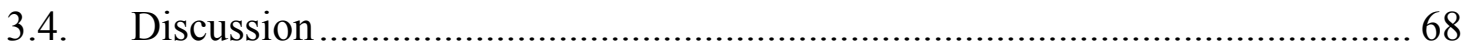

\section{INDUCTION OF P-GLYCOPROTEIN AND CYP3A ACTIVITIES IN LS174T}

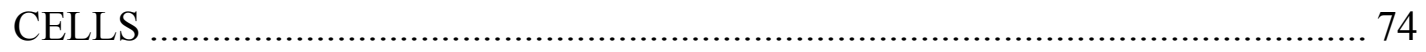

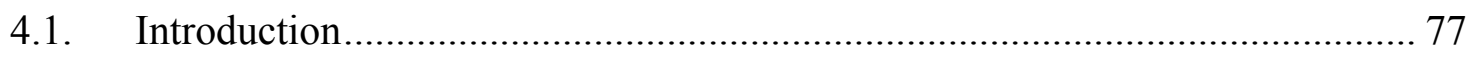

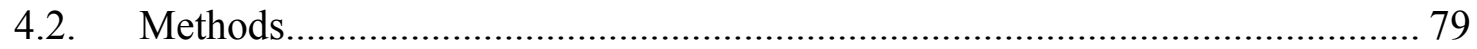

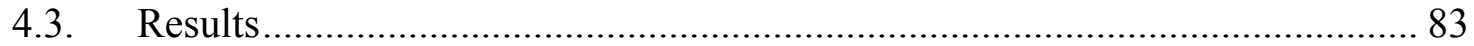

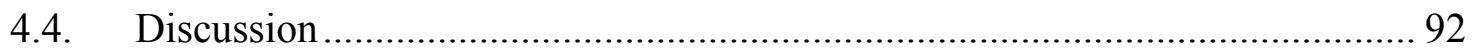

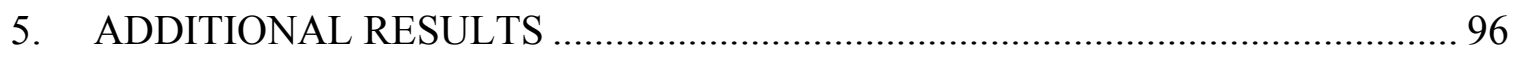

5.1. Sialic acid assay to determine the orientation or sidedness of membrane

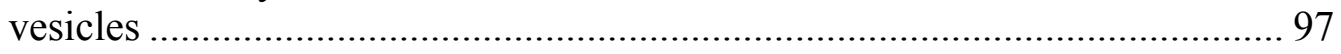

5.2. Alkaline phosphatase assay to determine the enrichment of vesicles as well as the orientation of membrane vesicles .............................................................98

5.3. Uptake of radiolabeled substrate in membrane vesicles .................................... 99

5.4. Induction studies in BeWo and JAR placental cells ........................................ 103

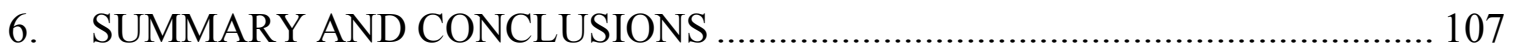

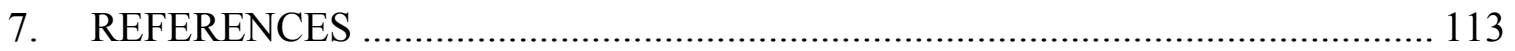




\section{List of Figures}

Figure 1-1 Schematic representation of ABC efflux transporter structure ...................... 5

Figure 1-2 Venn diagram showing the substrate overlap between P-gp and ABCP ...... 15

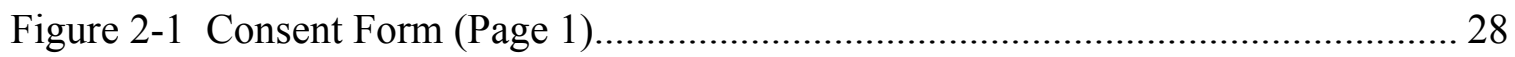

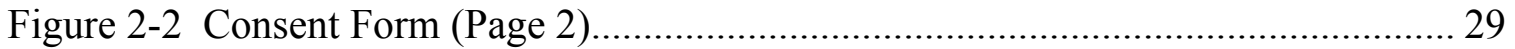

Figure 3-1 Representative immunoblot of P-gp in placental vesicles .......................... 57

Figure 3-2 Effect of osmolarity on ATP dependent uptake of $\left[{ }^{3} \mathrm{H}\right]$-vinblastine in

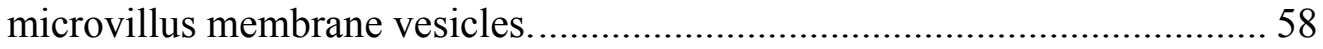

Figure 3-3 Effect of verapamil on ATP dependent uptake of vinblastine in microvillus

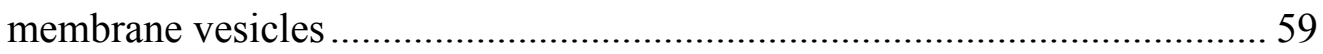

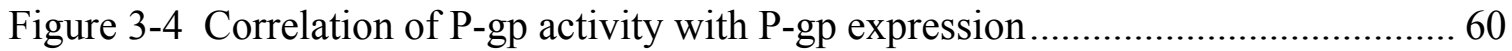

Figure 3-5 Effect of an ABCP inhibitor (FTC) and a P-gp inhibitor (VER) on the uptake of mitoxantrone in microvillus membrane vesicles ....................................6 63

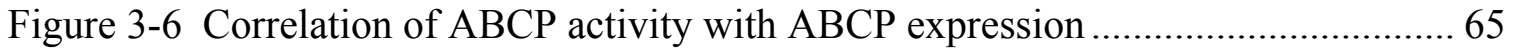

Figure 3-7 Immunoblot expression of $\mathrm{ABCP}$ in the presence and absence of reducing conditions

Figure 3-8 Effect of $1 \mathrm{mM}$ dithiothreitol (DTT) on ATP dependent uptake of mitoxantrone by $\mathrm{ABCP}$ in placental vesicles from two subjects (PT-20 and PT-22)

Figure 4-1 Dose dependent induction of immunoreactive P-glycoprotein after rifampin treatment

Figure 4-2 Determination of surface expression of P-gp in LS174T cells after treatment with rifampin and reserpine for 72 hours.

Figure 4-3 Uptake of vinblastine in control and rifampin treated cells in the presence and absence of $5 \mu \mathrm{M}$ cyclosporin A (CsA) ................................................... 86

Figure 4-4 Induction of CYP3A activity after $10 \mu \mathrm{M}$ rifampin treatment. .................... 88

Figure 4-5 Comparison of PXR Activation and P-gp Induction by Various Agents...... 90

Figure 4-6 Correlation between the rank order for PXR Activation and Induction of P-gp expression

Figure 5-1 Time course of $\left[{ }^{3} \mathrm{H}\right]$-vinblastine uptake in membrane vesicles 102 
Figure 5-2 Immunoblot of ABCP from JAR placental cell lysates probed with anti-MXR

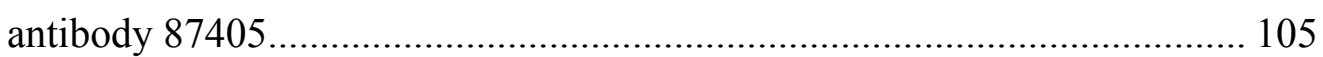

Figure 5-3 Immunoblot of ABCP from human placental samples and JAR placental cell lysates probed with BXP-21 primary antibody for ABCP........................ 106 


\section{List of Tables}

Table 1-1 Division of ABC superfamily of transporters into seven subfamilies.............. 3

Table 1-2 New nomenclature for the ABC transporter proteins .................................... 3

Table 3-1 Expression of P-gp and ABCP in placental vesicles ...................................56

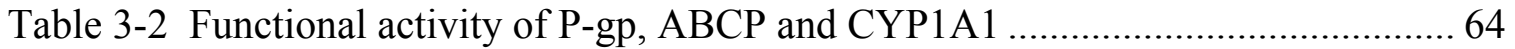

Table 5-1 Non-specific binding of $\left[{ }^{3} \mathrm{H}\right]$-vinblastine to nitrocellulose and glass fiber $(\mathrm{GF} / \mathrm{F})$ filters and effect of blocking solutions to reduce the non-specific

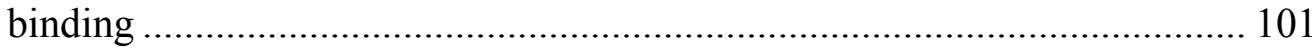




\section{List of Terms and Abbreviations}

3-MC

$\mathrm{ABC}$

$\mathrm{ABCP}$

Ah receptor

ATP

BBB

BCRP

CNS

CT

CYP

CYP1A1

CYP3A

DMSO

DNA

ECL

EROD

FBS

FTC

$\mathrm{kDa}$

$\mathrm{KO}$

MDR

$\mathrm{mdr}$

mRNA

MRP

MX

MXR

NADPH

$\mathrm{PAH}$

P-gp

PXR

RIF

SNP

ST

TCDD

VBL

VER

WT 3-methylcholanthrene

ATP Binding Cassette

$\mathrm{ABC}$ transporter in placenta

Aromatic hydrocarbon receptor

Adenosine 5'- triphosphate

Blood brain barrier

Breast cancer resistance protein

Central nervous system

Cytotrophoblast

Cytochrome P450

Cytochrome P450 1A1

Cytochrome P450 3A

Dimethylsulfoxide

Deoxyribonucleic acid

Enhanced chemiluminiscence

7-ethoxyresorufin- $O$-deethylase

Fetal bovine serum

Fumitremorgin C

Kilo dalton

Knock out mice

Multidrug resistance (human)

Multidrug resistance (mouse)

Messenger ribonucleic acid

Multidrug resistance protein

Mitoxantrone

Mitoxantrone resistance protein

$\beta$-nicotinamide adenine dinucleotide phosphate, reduced form

Polycyclic aromatic hydrocarbon

P-glycoprotein

Pregnane xenobiotic receptor

Rifampin

Single nucleotide polymorphism

Synctiotrophoblast

2, 3, 7, 8-tetrachlorodibenzo- $p$-dioxin

Vinblastine

Verapamil

Wild type mice 


\section{CHAPTER - I}

\section{LITERATURE REVIEW}


The placenta provides a link between mother and fetus, playing a critical role in the provision of nutrition and growth factors that are necessary for the development of the fetus. The placenta also plays a protective function by serving as a barrier against many xenobiotics reaching the fetus. Generally, it is preferred that the fetus not be exposed to xenobiotics; however, in certain cases the transfer of drugs to the fetus may be desired to achieve a positive therapeutic outcome. The placenta also possesses drug metabolizing enzymes (DME) that can assist in metabolizing drugs ingested by the mother and thus are prevented from entering the fetus. In addition to DMEs, it has also been demonstrated that efflux transporters are present in the placenta that can transport xenobiotics back to the mother and prevent fetal toxicity.

\subsection{Efflux Transporters}

The ATP- Binding Cassette (ABC) transporter superfamily represents the $\mathrm{ABC}$ genes which encode for transmembrane proteins. These proteins utilize ATP as the energy source to carry out efflux of xenobiotics and are termed as $\mathrm{ABC}$ transporters. These $\mathrm{ABC}$ transporters have ATP binding domains and transmembrane domains and depending on the number of domains, they are divided as full or half transporters. So far, $48 \mathrm{ABC}$ genes belonging to this $\mathrm{ABC}$ superfamily have been identified and the Human Genome Nomenclature Committee has developed a nomenclature system for the genes belonging to this superfamily. These genes have been classified into seven subfamilies, $\mathrm{ABCA}-\mathrm{ABCG}$, based on their sequence homology in ATP binding domains and transmembrane domains, similarities in gene 
structure and order of domains [1]. Table 1.1 lists the subfamilies and number of genes belonging to each subfamily. The members within each subfamily are then assigned an arabic number as a suffix. Out of the 48 transporters, 2 transporters studied by us are discussed in this manuscript and are listed in Table 1.2. The currently accepted nomenclature will be used throughout for consistency. An extensive list of 48 transporters can be found at http://nutrigene.4t.com/humanabc.htm

Table 1-1 Division of $\mathrm{ABC}$ superfamily of transporters into seven subfamilies

\begin{tabular}{|l|c|c|c|c|c|c|c|}
\hline Name & ABC1 & MDR & MRP & ALD & OABP & GCN20 & White \\
\hline Subfamily & ABCA & ABCB & ABCC & ABCD & ABCE & ABCF & ABCG \\
\hline Members & 12 & 11 & 12 & 4 & 1 & 3 & 5 \\
\hline
\end{tabular}

Table 1-2 New nomenclature for the ABC transporter proteins

\begin{tabular}{|c|c|c|}
\hline $\begin{array}{c}\text { Old nomenclature for the } \\
\text { gene }\end{array}$ & $\begin{array}{c}\text { New nomenclature for the } \\
\text { gene }\end{array}$ & $\begin{array}{c}\text { Protein encoded by the } \\
\text { gene }\end{array}$ \\
\hline$M D R 1$ & $A B C B 1$ & P-gp \\
\hline$B C R P / M X R / A B C P$ & $A B C G 2$ & BCRP / MXR/ABCP \\
\hline$M R P$ & $A B C C 1-6$ & MRP $1-6$ \\
\hline
\end{tabular}




\subsection{P-glycoprotein (P-gp)}

P-gp is encoded by the $A B C B 1$ gene which belongs to the adenosine 5'triphosphate (ATP) binding cassette superfamily of proteins known as ABC transporters. The proteins belonging to this superfamily utilize ATP as the energy source to carry out the active efflux of xenobiotics. P-gp is a 1280 amino acid transmembrane protein with a molecular weight of $170 \mathrm{kDa}$. The $A B C B 1$ gene has been mapped to choromosome 7q21.1 [2;3]. Structurally, P-gp has a total of 12 transmembrane domains divided into homologous regions (Figure 1.1). Each half contains 6 transmembrane domains and an intracellular ATP binding domain (also known as a nucleotide binding domain) [4]. These transmembrane domains bind to hydrophobic drugs and pump them out of cells. The development of resistance to chemotherapeutic agents in some tumor cells is attributable to the active efflux of these agents by P-gp. This efflux utilizes the energy from ATP hydrolysis. With the help of stoichiometric studies it has been shown that two ATP molecules are hydrolyzed for the transport of each substrate molecule $[5 ; 6]$. However both these events do not take place simultaneously, rather there are two independent ATP hydrolysis events in a single catalytic cycle [7]. Hydrolysis of one ATP molecule results in transport of the substrate whereas the other causes a conformational change necessary to reset the efflux pump for the next catalytic cycle [7]. 


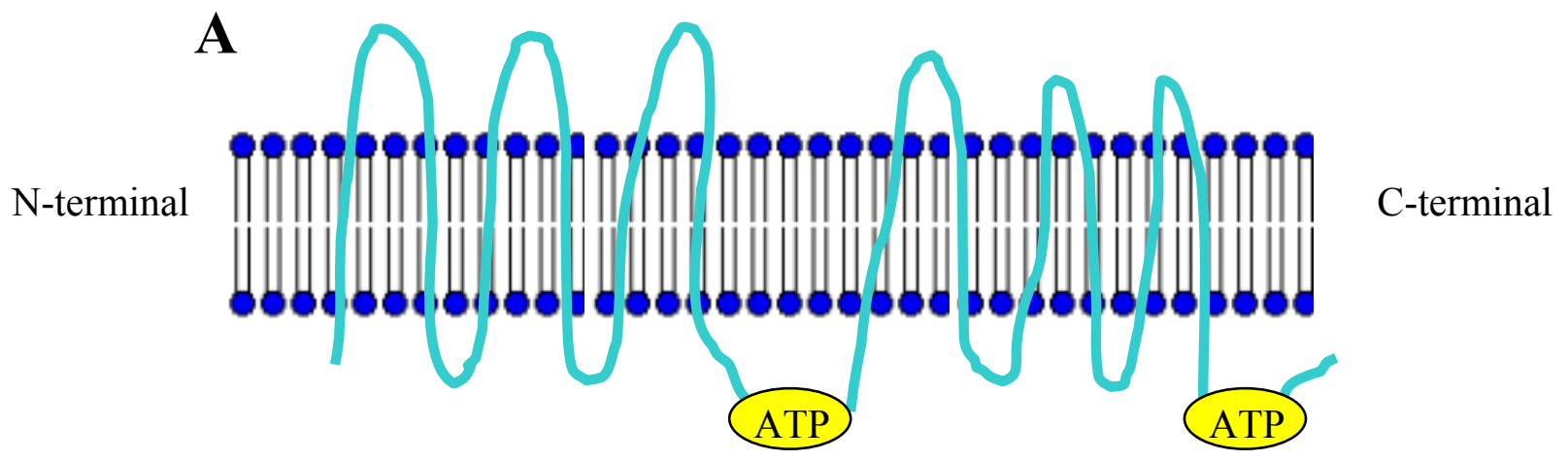

B

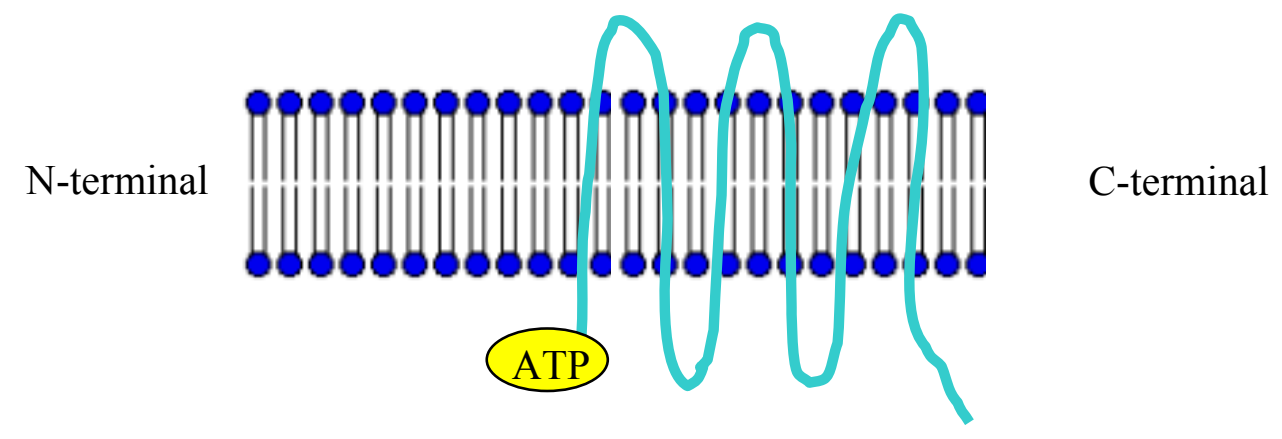

Figure 1-1 Schematic representation of $A B C$ efflux transporter structure

The structures of ABC efflux transporters: P-gp (A), encoded by $A B C B 1$ gene, which has 12 transmembrane domains and two ATP binding sites and ABCP (B), encoded by $A B C G 2$ gene, which has 6 transmembrane domains and one ATP binding site. The Nterminal is the amino terminal and C-terminal is the carboxy terminal. Figure adapted from Gottesman et al. [8]. 


\subsubsection{Tissue Distribution and Function of P-gp}

P-gp is present not only in tumor cells but also in normal tissues [9] and plays a very important role in the absorption, distribution and excretion of drugs. It is expressed in the intestinal epithelium whereby it pumps drugs back into the gut lumen, thus affecting absorption and decreasing oral bioavailability. Located at the apical membranes of hepatocytes and proximal tubules of the kidney, P-gp transports drugs into bile and urine, respectively, thus facilitating their biliary and urinary elimination. The blood brain barrier (BBB) prevents a variety of xenobiotics from entering the brain and helping prevent central nervous system (CNS) toxicity. P-gp is located on the luminal surface of the capillary endothelium of the BBB and facilitates efflux of xenobiotics back into the blood, thus reducing CNS exposure.

Animal models have been utilized to study the role of P-gp in the transport of xenobiotics. Although humans express a single $A B C B 1$ gene, there are two highly homologous $m d r l$ genes in mice, termed $m d r l a$ and $m d r l b$. Substantial overlap is seen in substrate specificity and tissue distribution between the P-gp's from mouse and human and therefore these transporters are believed to play similar roles in these species [10]. Due to these similarities, an $m d r$ knockout (KO) mouse, created by a targeted disruption of the $m d r$ gene, has proven to be a very useful model to study the contributions of P-gp in drug pharmacology. Kim et al. [11] in a study with KO mice demonstrated that plasma levels of HIV protease inhibitors like indinavir, saquinavir and nelfinavir, P-gp substrates, were 2 - 5 times higher in mdrla $\mathrm{KO}$ mice as compared to wild type (WT) mice. In addition, these investigators also found the concentrations of these drugs to be 7-36 fold higher in the brains of $\mathrm{KO}$ mice after 
intravenous administration as compared to WT. A subpopulation of CF-1 mice that is naturally deficient in $m d r l a$ has also been used in similar studies to understand the role of P-gp as these mice are phenotypically similar to the $m d r$ KO mice. Kwei et al. [12] used these mdrla deficient mice to investigate the disposition of ivermectin and cyclosporin A. Higher concentrations of ivermectin and cyclosporin A were seen in the brain and blood of mdrla deficient mice as compared to CF-1 WT mice after intravenous or oral administration. These studies demonstrated that P-gp not only governs the absorption and distribution of drugs but also plays a protective role by preventing the transport of drugs across the BBB. In addition to being expressed at the brain capillary endothelium, P-gp is also expressed in placenta. Lankas et al. performed studies in the mdrla deficient mice and its findings provided evidence for the role of placental P-gp in protection of the developing fetus [13]. An isomer of the pesticide avermectin, a substrate for P-gp, is known to produce cleft palate. The pregnant dams were exposed to this isomer and the susceptibility of the fetus to develop cleft palate was determined. The homozygous fetuses $(+/+)$, which had abundant P-gp, were totally insensitive to this teratogen whereas the homozygous fetuses (-/-), which were deficient in P-gp, were completely susceptible to developing cleft palate. The heterozygote fetuses (+/-) had a moderate effect due to intermediate expression levels of P-gp [13]. Since mice have two $m d r$ genes, $m d r 1 a$ and $m d r 1 b$, it was thought that $m d r 1 \mathrm{~b}$ would be upregulated in the mdrla $\mathrm{KO}$ mice as a compensatory mechanism. Therefore to nullify all $m d r$ activity, Smit et al. used KO mice in which both the $m d r$ genes, $m d r l a$ and $m d r 1 b$, were disrupted. These mice were used to study the transport of P-gp substrates digoxin, saquinavir and paclitaxel 
in pregnant heterozygous $m d r$ mice [10]. They demonstrated that the placental P-gp reduced the transfer of drugs to the fetus with the most reduction found in the WT fetuses $\left(m d r l a^{+/+} / 1 b^{+/+}\right)$as compared to heterozygous fetuses $\left(m d r l a^{+/-} / 1 b^{+/}\right)$and KO fetuses $\left(m d r 1 a^{-/-} / 1 b^{-/}\right)$. They further demonstrated that after oral administration of P-gp inhibitors like PSC833 or GF120918, drug levels in WT mice were comparable to KO mice and much higher than WT vehicle treated mice. These studies demonstrate the importance of placental P-gp in limiting the fetal exposure of potential chemical teratogens. It also suggests that modulation of placental P-gp can increase the transfer of drugs across the placenta to the fetus if the fetus is the patient and transfer is desirable for a therapeutic outcome.

\subsubsection{Substrates and Inhibitors of $P$-gp}

The phenomenon of multidrug resistance found during the treatment of cancer has been partly attributed to transporters such as P-gp. P-gp is involved in the transport of a large variety of drugs used for numerous disorders including cancer (doxorubicin, vinblastine, paclitaxel) and AIDS (amprenavir, saquinavir). An extensive list can be found at www.aidsinfonyc.org. These drugs differ not only functionally but also structurally. Most of the drug substrates are hydrophobic but can be neutral or positively charged. To understand the broad substrate specificity, researchers have carried out mutation analysis, which demonstrated that mutations in the transmembrane domains affect P-gp functionality. These results suggest that the binding sites are broad regions of recognition [14]. In addition, Martin et al. [15] 
have demonstrated, using several substrates and modulators of P-gp in radioligand binding studies, that P-gp has a minimum of four distinct drug binding sites and there is an allosteric interaction between the sites.

Inhibition of P-gp to increase the effectiveness of cancer chemotherapeutic agents is thought of as one route of decreasing multidrug resistance. The first generation of P-gp inhibitors (cyclosporin A, verapamil) were drugs that were used for other therapeutic purposes. Due to toxicity issues, a second generation of inhibitors for e.g. PSC833, which are analogs of the first generation agents for e.g. cyclosporin A were developed. LY335979 is by far the most potent and selective inhibitor of P-gp. A thorough review of interactions of P-gp with its substrates and inhibitors has been presented by Litman et al. [14].

\subsubsection{Induction, regulation and drug-drug interactions of $P$-gp}

Many P-gp substrates are also P-gp inducers. In LS180/WT and its adriamycin resistant subline LS180/AD50, P-gp was upregulated after treatment with various drugs including rifampin, phenobarbital, clotriamazole, reserpine, midazolam, nifedipine and isosafrole. An increase in $A B C B 1$ mRNA on treatment with rifampin and reserpine suggested that P-gp is upregulated at the transcriptional level rather than at the post-translational level [16]. $A B C B 1$ mRNA was also upregulated by polycyclic aromatic hydrocarbons (PAHs) like 3-methylcholanthrene (3-MC) and 2,3,7,8-tetrachlorodibenzo-p-dioxin (TCDD) in primary human hepatocytes. However a polymorphic inducibility was seen where 3-MC and TCDD induced 
$A B C B 1$ mRNA in only $62 \%$ and $55 \%$ of the preparations respectively. These results suggest that although aromatic hydrocarbons upregulate $A B C B 1$, the induction does not occur via the classical Ah receptor pathway [17]. Polli et al. [18] have demonstrated that HIV protease inhibitors like amprenavir and nelfinavir are not only substrates of P-gp but also induce P-gp. Western blot analysis revealed that amprenavir and nelfinavir both increased the expression of intestinal P-gp but not of hepatic P-gp in rats, suggesting a tissue specific induction. The difference in P-gp induction could also be due to reduced concentrations of these drugs reaching P-gp in the liver as they might be metabolized by hepatic CYP3A4, which itself is induced by these drugs.

Due to its wide substrate specificity and inducibility, P-gp plays a very important role in drug-drug interactions. In-vitro experiments and animal studies have shown that fexofenadine [19] and digoxin [20;21] both are substrates for P-gp and are primarily excreted unmetabolized. Concomitant administration of rifampin with digoxin reduced the oral bioavailability of digoxin in healthy males by $30 \%$ and a 3.5 fold increase was seen in intestinal P-gp expression [22]. Similarly Hamman et $a l$. have shown that rifampin therapy reduced the bioavailability of fexofenadine, which they attributed to the induction of intestinal P-gp [23].

Recent studies have helped us understand the mechanism of regulation of P-gp at the molecular level. Synold et al. [24] have recently shown that the pregnane $\mathrm{X}$ receptor (PXR), a nuclear hormone receptor, regulates drug efflux by activating the expression of the $A B C B 1$ gene. Paclitaxel (taxol), a commonly used antineoplastic agent is an efficient and selective activator of PXR and induces $A B C B 1$ mediated 
drug efflux. However, docetaxel (taxotere), an analog of paclitaxel, did not activate PXR or induce the $A B C B 1$ mediated drug efflux. Ecteinascidin-743 (ET-743) is an antineoplastic agent and has been shown to inhibit trichostatin-induced transcription of $A B C B 1$ [25;26]. Synold et al. [24] found that ET-743 can repress the ligand mediated activation of PXR thus inhibiting the transcriptional activation of $A B C B 1$. In addition, Geick et al. found PXR response elements, essential for $A B C B 1$ induction by rifampin, to be present in the upstream region of human $A B C B 1$ [27]. These studies support the role of PXR in regulation of P-gp, however, it might not be solely responsible for P-gp induction and other regulatory pathways may exist given that Pgp is also induced by some Ah receptor ligands.

\subsubsection{Genetic Polymorphism in P-gp}

As mentioned above, phenotypic variability was reported in the induction of P-gp by PAHs [17]. In addition, substantial interindividual variability was seen in expression of hepatic P-gp within and between males and females [28]. Also, disposition of P-gp substrates varies between individuals [29;30] and this could be important for drugs with narrow therapeutic indices. These reports underscore the importance of genotyping studies to determine if any polymorphisms exist that may explain the observed inter-individual differences. In-vitro studies have suggested that amino acid changes in the $A B C B 1$ gene leads to altered activity [31;32]. A total of 15 polymorphisms were identified by Hoffmeyer et al. in the $A B C B 1$ gene in a Caucasian population. The authors demonstrated a significant correlation between 
the single nucleotide polymorphism (SNP) at exon 26 (C3435T) and P-gp expression and activity in the duodenum. Individuals with the T/T allele had lower P-gp expression and higher plasma concentrations of digoxin [33]. P-gp genotyping studies in Japanese women showed that in addition to the SNP at exon 26 (C3435T), which was present in $93.8 \%$ of women in the study, these individuals also had a SNP at exon 21 G2677 (A/T) [34]. This suggests an association between these two SNPs. Later, Kim et al. [35] found the following 3 SNPs to be present simultaneously in 62 \% of European Americans and 13\% of African Americans: C1236T in exon 12, G2677T in exon 21 and C3435T in exon 26. Using fexofenadine as a probe drug, these individuals were phenotyped for P-gp activity. The results suggested that the individuals who had the T/T homozygous allele in both exon 21 and exon 26 had lower plasma concentrations of fexofenadine suggesting an increased expression of Pgp as compared to the individuals containing the homozygous $\mathrm{G} / \mathrm{G}$ and $\mathrm{C} / \mathrm{C}$ allele in exon 21 and exon 26, respectively. These results are however contradictory to the results published by Hoffmeyer et al. [33] and Tanabe et al. [34]. Thus, the effects of genetic polymorphisms with respect to the direction of change in P-gp expression and activity are still unclear. Further studies are needed to understand the effect of these polymorphisms not only on the level of expression but also the functional activity of P-gp. 


\subsection{ABCP (BCRP / MXR)}

Placenta-specific ATP binding cassette gene (ABCP) [36] also known as breast cancer resistance protein (BCRP) [37] or mitoxantrone resistance associated protein (MXR) [38], is encoded by $A B C G 2$ which belongs to the $A B C G$ subfamily. $A B C G 2$ gene is located on chromosome $4 \mathrm{q} 22$. ABCP is a 655 amino acid transmembrane protein with a molecular weight of $70 \mathrm{kDa}$. ABCP utilizes energy from ATP hydrolysis to function as an efflux transporter. It has only 6 transmembrane domains and an intracellular ATP binding domain towards the Nterminal (Figure 1.1). ABCP exists as a half transporter and is half the size of other ABC transporters like P-gp which has 12 transmembrane domain and two ATP binding domains. The half transporters usually dimerize to become functional and $\mathrm{ABCP}$ is assumed to be a functional dimer. Though no dimerization partner has been identified so far, current transfection data suggest it is functional as a homodimer [14]. It was reported that $\mathrm{ABCP}$ migrates as a $70 \mathrm{kDa}$ protein under reducing conditions and as a $140 \mathrm{kDa}$ complex under non-reducing conditions. These results suggest that $\mathrm{ABCP}$ forms a homodimer via the disulfide linkage [39].

\subsubsection{Substrates and Inhibitors of $\mathrm{ABCP}$}

ABCP offers resistance to a variety of substrates and exhibits considerable substrate overlap with P-gp, as shown in Figure 1.2 adapted from Litman et al. [14]. Mitoxantrone and topotecan are good substrates for $\mathrm{ABCP}$ and overexpression of 
$\mathrm{ABCP}$ has been reported in both mitoxantrone and topotecan resistant cells $[40 ; 41]$. A number of functional assays have been developed to determine the functional activity of $\mathrm{ABCP}$ and to screen for drugs that interact with the protein. Some of the substrates that are transported by $\mathrm{ABCP}$ are the anthracyclines, $\mathrm{SN}-38$ [42], bisantrene, rhodamine 123, LysoTracker Green, prazosin and its fluorescent analog BODIPY-prazosin [43].

Fumitermorgin C (FTC) [44] and GF120918 [45] are effective inhibitors of $\mathrm{ABCP}$ and increase the intracellular accumulation of $\mathrm{ABCP}$ substrates in $\mathrm{ABCP}$ overexpressing cells. FTC is a potent and selective inhibitor of ABCP whereas GF120918 is a potent inhibitor but not selective and is know to inhibit P-gp as well. More than 20 analogs of FTC have been analyzed for their inhibitory action on ABCP but none had equal or better activity or selectivity than FTC for ABCP [46]. Recently, it was demonstrated that estrone and $17 \beta$-estradiol also inhibit $\mathrm{ABCP}$ and increase the intracellular accumulation of topotecan in drug resistant cells that overexpress $\mathrm{ABCP}[47]$. 


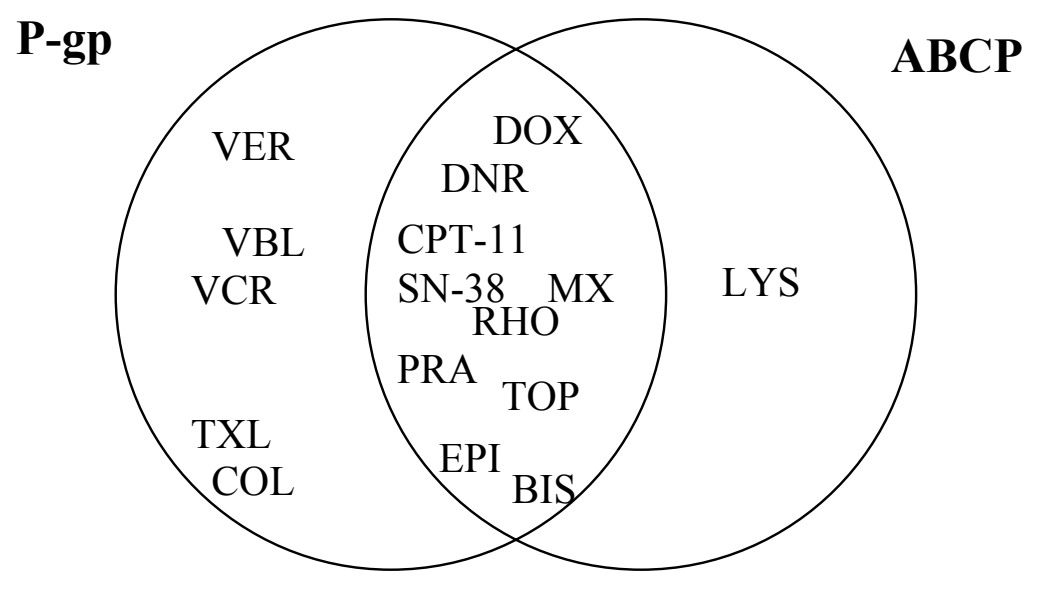

Figure 1-2 Venn diagram showing the substrate overlap between P-gp and $\mathrm{ABCP}$

Abbreviations: BIS, bisantrene; CPT-11, Topotecan; DNR, daunorubicin; DOX, doxorubicin; EPI, epirubicin; LYS, LysoTracker; MX, mitoxantrone; PRA, prazosin; RHO, rhodamine 123; SN-38, metabolite of CPT-11; TXL, taxol; TOP, topotecan; VBL, vinblastine; VCR, vincristine; VER, verapamil. Figure adapated from Litman et al. [14]. 


\subsubsection{Tissue distribution, location and function of $\mathrm{ABCP}$}

Observation of drug resistance and reduced drug accumulation in multidrug tumor cells which did not show overexpression of P-gp or MRPs led to the discovery of $\mathrm{ABCP}$, a new member of $\mathrm{ABC}$ superfamily of transporters. These cell lines are derived from breast cancer [37], ovarian carcinoma [41] and colon carcinoma cells [44]. Using immunohistochemical staining, ABCP has been predominantly localized to plasma membranes [48]. Apart from being expressed in cancerous tissue, $\mathrm{ABCP}$ has also been reported to be present in normal tissues. Tissue distribution of $A B C G 2$ mRNA was determined by northern blotting and found to be present predominantly in placenta and to a lesser extent in brain, small intestine, liver, colon ovary, testis and prostate [37]. ABCP protein has also been reported to be expressed prominently in placenta, liver, small intestine and colon of humans [49]. This expression corresponded with $A B C G 2$ mRNA levels measured by RT-PCR. The murine breast cancer resistance protein (bcrp1) is highly homologous to human ABCP with $81 \%$ amino acid identity [50]. The bcrp1 mRNA was however found to be highly expressed in kidney and to a lesser extent in placenta as compared to humans [51]. A new multidrug resistance protein has been identified in porcine brain capillary endothelial cells that is closely related to ABCP with $86 \%$ amino acid identity [52]. The tissue distribution of ABCP is similar to P-gp distribution and suggests it may play a role in the absorption, distribution and elimination of drugs. Its substantial expression in placenta also suggests ABCP may serve as a protective barrier which prevents the transport of its substrates across the placenta and to the fetus. In order to understand the role of bcrp in placenta, Jonker et al. [51] measured 
the bioavailability of topotecan in fetuses of wild type mice and $m d r l a / 1 b$ knockout mice. The mdr la/lb knockout mice were used to control for the contribution of P-gp, since some overlap in substrate specificity exists. The authors reported that the bioavailability of topotecan in the presence of GF120918, an ABCP and P-gp inhibitor, was six fold higher in KO mice and nine times more in the WT mice as compared to the respective vehicle treated mice. Also, a two fold higher fetal exposure of topotecan was seen in KO mice treated with GF12098 than in vehicle treated KO mice [51]. These results suggest an important role for bcrp in fetal exposure to drugs. To date, there are no reports on functionality of $\mathrm{ABCP}$ in human placenta. However, with the knowledge that $\mathrm{ABCP}$ is highly expressesed in human placenta and that there is homology between the mouse bcrp and human $\mathrm{ABCP}$, one can assume that $\mathrm{ABCP}$ in addition to P-gp plays an important role in limiting the fetal exposure to various xenobiotics during pregnancy.

\subsubsection{Mutations / polymorphisms in $\mathrm{ABCP}$}

Of the 9 cell lines studied, Rhodamine 123, a substrate for $\mathrm{ABCP}$, was transported in some but not all $\mathrm{ABCP}$ overexpressing cells whereas mitoxantrone was transported in all cell lines. On seqencing the genomic DNA, mutations in the amino acid at position 482 were found. The wild type $\mathrm{ABCP}$ has an arginine (R) at postion 482 whereas some cells had either threonine (T) or glycine (G) at this position. The mutated cells (R482T or R482G) were able to carry out the transport of rhodamine 123 in contrast to the wild type cells. The transport of doxorubicin also was shown to 
be affected by the mutations. These results suggest that the amino acid at position 482 may be critical in binding of the substrate to the transporter, thus affecting substrate transport. It should also be noted that the mutational effects observed are substrate dependent. As these mutations change the substrate specificity they may lead to alterations in drug resistance phenotype [53]. Recently, similar results were seen in mouse cell lines overexpressing bcrp1. Mutations at position 482 were seen, however, in murine cells arginine was replaced by methionine (M) and serine (S) [54] as opposed to threonine and glycine in humans. Genotyping studies to determine if such polymorphisms exist in normal human tissues are needed and should be accompanied by phenotyping studies to understand the impact of these amino acid changes in function of $\mathrm{ABCP}$. Recently, Zamber et al. [55] performed an $\mathrm{ABCP}$ genotyping study using human intestinal samples from 11 different ethnic populations and have reported the presence of several SNPs, with G34A and C421A being the two most frequent SNPs observed. Interestingly, the mutations observed in the drug selected cell lines resulting in an amino acid change at position 482 were not detected in any of the human intestinal samples and thus were attributed to acquired mutations due to drug selection. There was significant variation in the expression of $\mathrm{ABCP}$ mRNA and protein between individuals and on an average expression was higher in females than males. However, no correlation was observed between the most frequent polymorphisms and the level of $\mathrm{ABCP}$ expression. Whether these polymorphisms have an effect on $\mathrm{ABCP}$ function in humans is yet to be determined. 


\subsection{Cytochrome P450 1A1 (CYP1A1)}

The human CYP1 family contains CYP1A1, CYP1A2 and CYP1B1

[56;57]. CYP1A2 is found primarily in hepatic tissue whereas CYP1A1 and CYP1B1 are extrahepatic in nature. CYP1A1 and CYP1A2 belong to the CYP1A subfamily and are approximately $68 \%$ identical in their sequence [58].

CYP1A1, also known as aromatic hydrocarbon hydroxylase, is responsible for metabolism of environmental carcinogens such as polycyclic aromatic hydrocarbons (PAH). Benzo[a]pyrene, a PAH, is principle constituent of cigarette smoke. It is a procarcinogen and is metabolized by CYP1A1 to mutagenic and carcinogenic compounds. CYP1A1 is highly inducible by PAHs, cigarette smoking and polychlorinated biphenyls (PCB). The mechanism of induction of CYP1A enzymes is well studied and understood. The inducing agent (ligand) binds to cytosolic aromatic hormone receptor (Ah receptor) and this receptor is translocated to the nucleus where it binds to Ah receptor nuclear translocator (ARNT) protein. This complex then binds to the DNA of the CYP1A1 gene and enhances its rate of transcription. There is inter-individual variability in the induction of CYP1A1 which might be related to the genetic differences in the Ah receptor expression [59].

Of the CYP1A family, CYP1A1 and CYP1B1 are found in human placenta. CYP1A2 is not found in placenta; however, its mRNA can be detected in the first trimester (10-12 weeks of gestation) of pregnancy. CYP1A1 mRNA as well as the protein has been found in full term placentas $[60 ; 61]$. The 7-ethoxyresorufin $O$-deethylase (EROD) reaction is mainly catalyzed by CYP1A1 and is used as an activity marker for this enzyme. Constitutive CYP1A1 activity is very low or 
unmeasurable in placentas, however, this activity increases with maternal cigarette smoking [62]. CYP1A1 gets induced to a variable extent depending on stage of pregnancy with the highest activity being seen at term [63]. Immunohistochemical analysis has shown that the cigarette smoke induced CYP1A1 is localized over both synctiotrophoblastic and cytotrophoblastic areas [64] of the placenta. 


\subsection{Placenta}

The placenta is the sole link between the mother and the fetus. It carries out the transport of essential nutrients, oxygen and water from mother to the fetus as well as removing waste products from the fetus. It performs the necessary functions of several fetal organs such as the liver, lungs, kidney etc. until these organs are fully developed. The placenta is a disc shaped tissue and has two plates namely chorionic and basal plate which faces the fetus and mother, respectively [65]. Villous tissue present between these two plates is perfused with maternal blood. The placental villi are tree like structures originating from the chorionic plate and are lined with trophoblastic cells [66]. Transfer of xenobiotics across the placenta proceeds both passively and via various transporters that are expressed in villi in a polarized fashion. These transporters are expressed differentially in the maternal-facing brush border and the fetal-facing basal membrane of syncytiotrophoblast (ST) cells, which is known as the functional unit of placenta. ST is multinucleated and is formed as the pregnancy advances by the fusion of uninucleated cytotrophoblastic cells. In addition to physiological substrates, the transporters present in the membranes of ST also transport xenobiotics which include therapeutic agents, environmental pollutants and drugs of abuse. Therapeutic agents used to treat the mother may cross the placental barrier and have untoward effects on the fetus. On the other hand, in cases such as where the fetus is HIV infected, placental transfer of therapeutic agents is desirable for a positive therapeutic outcome. In addition to transporters, there are also some drug metabolizing enzymes present in the placenta which alter the passage of xenobiotics across the placenta. These enzymes primarily metabolize xenobiotics to 
make them more water soluble and thus increase their elimination; however, toxic and / or reactive metabolites may also be produced.

The brush border membrane of the ST faces the mother and is in direct contact with maternal blood whereas the basal membrane faces the fetal blood circulation. The brush border (microvillus) membrane is made up of microvilli that increase the surface area of the membrane. There is evidence of efflux transporters, belonging to the $\mathrm{ABC}$ superfamily of proteins, such as $\mathrm{P}$-gp, $\mathrm{ABCP}$ and some of the MRPs, being present in the microvillus membrane of the placenta. Due to their efflux nature, these transporters expressed in microvillus membranes can pump xenobiotics back to mother and thus may prevent fetal toxicity.

P-gp is abundantly expressed in human placental trophoblast cells $[9 ; 67]$ and this expression is selectively seen in trophoblast cells of first trimester placenta. In full term placenta, P-gp was found in Hofbauer cells and placental macrophages. However, Nakamura et al. also demonstrated the presence of P-gp in trophoblasts from full term placenta [68]. Uptake of radiolabeled vincristine in microvillus membrane vesicles isolated from trophoblast cells confirmed the expression of active P-gp in the placenta. However, these investigators reported a smaller size P-gp (160 $\mathrm{kDa}$ ) to be present in trophoblast, whereas others have reported a $170 \mathrm{kDa}$ P-gp in primary human cytotrophoblasts [69] which could be due to differences in posttranslational modifications such as glycosylation. Primary cultures of human cytotrophoblasts and BeWo cells, a choriocarcinoma cell line, have also been used to study the functional expression of P-gp [69;70]. 
Apart from P-gp, other multidrug transporters are also present in placenta. With the help of sensitive molecular techniques, multidrug resistance associated protein (MRP) was found to be present in human placenta. At least 3 different MRP mRNAs have been identified in placenta [71]. MRP1 and MRP5 are present and functionally active in BeWo cells [72] and are involved in the transport of unconjugated bilirubin. The most recently discovered $\mathrm{ABC}$ efflux transporter, $\mathrm{ABCP}$ (BCRP / MXR), is reported to be highly expressed in the plasma membrane of syncytiotrophoblastic cells of the placenta [73]. High endogenous expression of ABCP was also found in the human choriocarcinoma cell lines JAR, JEG-3 and BeWo [74]. However, there are no reports on the functionality of $\mathrm{ABCP}$ in human tissues and whether this protein is functional in placenta is yet to be determined.

\subsection{Effect of smoking on placenta and placental enzymes and transporters}

Cigarette smoking has been associated with adverse outcomes during pregnancy including changes in function and structure of the placenta. Furthermore, increased fetal morbidity and mortality have been reported due to maternal smoking. Morphologically, changes such as thickening of the trophoblastic cells and decrease in volume density of fetal capillaries within terminal villi have been observed in smokers [75].

Smoking and associated polycyclic aromatic hydrocarbons (PAHs) can affect drug metabolizing enzymes expressed in placenta. The constitutive expression 
of CYP1A1 is low in placenta but is readily induced by xenobiotics. PAHs found in cigarette smoke are good inducers of CYP1A1, and high and variable CYP1A1 activity has been reported in placental microsomes from smokers as compared to nonsmokers [62].

To date, the effect of smoking on efflux transporters expressed in placenta has not been reported. P-gp, however, has been shown to be induced by various PAHs in rat and mouse liver. Of the PAHs studied, 3-MC and 2-acetylaminofluorene induced P-gp mRNA levels in primary cultures of hepatocytes in rats, however, TCDD was unable to induce P-gp mRNA levels at relevant concentrations of TCDD [76]. Similarly, in mouse liver, P-gp mRNA levels were induced by 3-MC but not by TCDD [77]. Interestingly, 3-MC and TCDD both induced P-gp mRNA levels in primary cultures of human hepatocytes. However, a phenotypic variability was seen in the induction [17] as only $62 \%$ and $55 \%$ of the primary hepatocyte cultures showed induction after treatment with 3-MC and TCDD respectively. Thus, in-vitro animal and human studies suggest that PAHs induce P-gp mRNA in liver, however, whether similar induction occurs in placenta is not known. In addition, PAH benzo-[a]pyrene, apart from being a substrate for CYP1A1, is also a substrate for P-gp [78]. Thus, analogous to the induction of CYP1A1, there could possibly be induction of Pgp levels in placentas of women who smoke during pregnancy, resulting in a protection of the fetus from the harmful effects of cigarette smoke constituents. Thus, we hypothesized that smoking might increase P-gp levels in human placenta. ABCP, another efflux transporter expressed in placenta, is also believed to play a protective role in placenta similar to P-gp. However there are no reports of functional studies of 
$\mathrm{ABCP}$ in human placenta and its regulation by cigarette smoke constituents. Thus, we studied the function and expression of P-gp and ABCP in placentas from smokers and non-smokers.

\subsection{Specific aims of this research}

1. Compare levels of P-gp activity and expression in human placentas from smokers and non-smokers.

2. Correlate levels of P-gp and CYP1A1 in human placentas from smokers and nonsmokers.

3. Compare levels of $\mathrm{ABCP}$ activity and expression in human placentas from smokers and non-smokers.

4. Evaluate the induction of P-gp by various xenobiotics in choriocarcinoma and colon carcinoma cell lines. 


\section{CHAPTER II}

\section{EXPERIMENTAL}




\subsection{Patient Selection}

Subjects were recruited through the Obstetrics and Gynecology Department at Ruby Memorial Hospital at West Virginia University. Placental samples were obtained using a protocol approved by the West Virginia University Institutional Review Board for the Protection of Human Research Subjects (Figure 2.1 and 2.2). Participants provided informed written consent prior to obstetric delivery. Placentas were collected from women (ages 18-36 years) who were full term (38 weeks and more). Subjects were smoking and non-smoking females with no concurrent disease states. Smoking status was determined via patient interview.

\subsection{Tissue Collection}

Placentas were collected and processed immediately after delivery. Two triangular wedges extending from center of the placenta to the placental margin were removed for processing. One piece was placed in a plastic bag, appropriately labeled and frozen at $-80^{\circ} \mathrm{C}$ for later preparation of placental microsomes. The other piece was immediately processed to prepare the membrane vesicles. 


\section{WestVirginiaUniversity}

SCHOOL OF PHARMACY

\section{CONSENT AND INFORMATION FORM}

Placental Transport of Drugs

WEST VIRGINIA UNIYEPSITY

Institution Review Board for the Protection of Human Research Subjects

NOV 142001

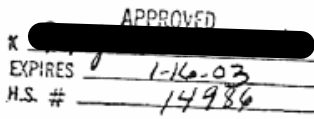

Introduction. I research study which has been explained to me by , have been invited to participate in this being conducted by Timothy Tracy, Ph.D and Douglas Glover, MD in the Departments of Basic Pharmaceutical Sciences and Obstetrics and Gynecology at West Virginia University.

Purpose of the Study. The purpose of this study is to learn more about the transport of drugs across the placenta.

Description of Procedures. This study involves recovery of the placental tissue after delivery from smoking and non-smoking subjects and testing of this tissue for its ability to allow drugs to pass. Approximately 20 non-smoking and 20 smoking subjects will be entered in this study.

Risks and Discomforts. The are no known or expected risks from participating in this study.

Alternatives. I understand that I have the right to refuse to participate in this study should I so desire.

Benefits. I understand that this study is not expected to be of direct benefit to me, but the knowledge gained may be of benefit to others.

Contact Persons. For more information about this research, I can contact, Dr. Timothy S. Tracy, at (304) 293-1474 or Dr. Douglas Glover, at (304) 293-5631. For more information regarding my rights as a research subject, I may contact the Executive Secretary of the Institutional Review Board at (304) 293-7073.

Confidentiality. I understand that any information about me obtained as a result of my participation in this research will be kept as confidential as legally possible. I understand also that my research records, just like hospital records, may be subpoenaed by court order or may be inspected by federal regulatory authorities. In any publications that result from this research, neither my name nor any information from which I might be identified will be published without my consent.

Version Date 10/19/01

Department of Basic Pharmaceutical Sciences

Robert C. Byrd Health Sciences Center PO Box 9530

Phone: $304-293-2170$ Fax: 304-293-2576

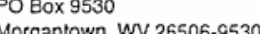

Initials/Date

Page 1 of 1

Fonal Onnertunitv/Affirmathro Antenn Inetitution

\section{Figure 2-1 Consent Form (Page 1)}

Consent form for placental transport of drugs approved by West Virginia University Institutional Review Board for the Protection of Human Research Subjects 
Voluntary Participation. Participation in this study is voluntary. I understand that I am free to withdraw my consent to participate in this study at any time. Refusal to participate or

withdrawal will involve no penalty or loss of benefits. I have been given the opportunity to ask questions about the research, and I have received answers concerning areas I did not understand.

Upon signing this form, I will receive a copy.

I willingly consent to participate in this study.

Signature of Subject or Subject's Legal Representative

$\overline{\text { Date }} \overline{\text { Time }}$

Signature of Witness

$\overline{\text { Date }} \overline{\text { Time }}$

Signature of Investigator

$\overline{\text { Date }} \quad \overline{\text { Time }}$

Version Date 10/19/01

Initials/Date

n... naf?

Figure 2-2 Consent Form (Page 2)

Consent form for placental transport of drugs approved by West Virginia University Institutional Review Board for the Protection of Human Research Subjects 


\subsection{Preparation of Microvillus and Basal Membrane Vesicles}

Microvillous membrane vesicles (MVM) and basal membrane vesicles (BMV) were prepared simultaneously from the same placenta within 30 min of delivery using a homogenization and differential centrifugation technique conducted according to the methods of Illsley et al. [79]. The tissue was cut into small pieces and washed several times in $0.9 \% \mathrm{NaCl}$. The washed tissue was further minced finely and suspended in 3 volumes of buffer 1 . The suspension was homogenized in $25 \mathrm{ml}$ aliquots for 2 min using a Virtisher tissue homogenizer and this was labeled as homogenate 1 which was centrifuged at 10,000 g for $15 \mathrm{~min}$. The supernatant (supernatant 1) was collected and the pellet resuspended in buffer 1, homogenized (homogenate 2) and centrifuged again. Both supernatant fractions were then combined, filtered through gauze and centrifuged at $47,500 \mathrm{~g}$ for $1 \mathrm{~h}$. The pellet was resuspended in buffer $1(15 \mathrm{mg} / \mathrm{ml})$ and to this $\mathrm{MgCl}_{2}$ was added (12 mM final concentration). The mixture was stirred on ice for $20 \mathrm{~min}$ and centrifuged at $2500 \mathrm{~g}$ for $15 \mathrm{~min}$. The supernatant and $\mathrm{Mg}^{2+}$ aggregated pellet was further processed to get the MVM and BMV respectively. The supernatant was centrifuged at 47,500 g for $30 \mathrm{~min}$. The obtained pellet (MVM) was washed and resuspended in buffer 2 after passage through a 25 -gauge needle, aliquoted and stored at $80^{\circ} \mathrm{C}$. The $\mathrm{Mg}^{2+}$ aggregated pellet was resuspended in buffer 2 , homogenized thoroughly and $15 \mathrm{ml}$ was layered onto a sucrose step gradient. The step gradient was constructed in 40ml Beckman SW 28 centrifuge tubes using a bottom fraction $(6 \mathrm{ml})$ with density 1.190 $\mathrm{gm} / \mathrm{cm}^{3}$ and a middle fraction $(17 \mathrm{ml})$ with density $1.165 \mathrm{gm} / \mathrm{cm}^{3}$. The gradient was centrifuged for 1 hour at 141,000 g using a Beckman SW 28 swing-out rotor with a slow acceleration and deceleration through $140 \mathrm{rpm}$. The resulting fraction at the interface of 
the bottom and middle steps was collected. This fraction was diluted with 10 volumes of buffer 2, homogenized and centrifuged at 47,500 g for $30 \mathrm{~min}$. The pellet (BMV) was resuspended in buffer 2 after passage through a 25 -gauge needle, aliquoted and stored at $80^{\circ} \mathrm{C}$. The entire procedure was carried out at $4^{\circ} \mathrm{C}$.

\section{Buffer 1:}

Buffer 1 consists of $10 \mathrm{mM}$ Tris $\mathrm{HCl}$ - Hepes (pH 7.0), $250 \mathrm{mM}$ sucrose, 5 mM EGTA, 5 mM EDTA and $1 \mathrm{mM}$ PMSF.

\section{Buffer 2:}

Buffer 2 consists of $10 \mathrm{mM}$ Tris $\mathrm{HCl}$ - Hepes (pH 7.4) and $250 \mathrm{mM}$ sucrose.

\subsection{BCA Protein Assay}

Membrane vesicle protein concentrations were determined using the BCA protein assay kit from Pierce. The assay was carried out in a 96 well, flat bottom polystyrene (clear) microtiter plate. Samples were diluted 1:10 (10 $\mu \mathrm{L}$ sample and $90 \mu \mathrm{L}$ of distilled $\left.\mathrm{H}_{2} \mathrm{O}\right)$ and 1:20 (5 $\mu \mathrm{L}$ sample and $95 \mu \mathrm{L}$ of distilled $\left.\mathrm{H}_{2} \mathrm{O}\right)$ with water and then vortexed. $20 \mu \mathrm{L}$ of standards (Bovine serum albumin $125 \mu \mathrm{g} / \mathrm{mL}-2000 \mu \mathrm{g} / \mathrm{mL}$ ) and diluted samples were pipetted in appropriate wells $(n=3)$. The BCA reagents were prepared according to the manufacturers instructions and $200 \mu \mathrm{L} /$ well was added by means of an Eppendorf repeating pipettor. The plate was shaken to mix the solutions and then incubated at $37^{\circ} \mathrm{C}$ for $30 \mathrm{~min}$. After allowing the plate to cool to room temperature, the 
absorbance was read at $562 \mathrm{~nm}$ on a Thermomax plate reader using Softmax Pro software.

\section{$\underline{\text { BCA protein reagents }}$}

Immediately prior to use, mix 1 part of reagent B $(0.5 \mathrm{ml})$ with 50 parts of reagent A (25 $\mathrm{ml})$.

\subsection{Sialic Acid Assay for Sidedness or Orientation of Membrane Vesicles}

The percentage of inside-out vesicles was determined by the accessibility of sialidase to sialic acid in the presence and absence of detergent. Briefly, aliquots of vesicles containing $100-300 \mu \mathrm{g}$ of protein in $50 \mu \mathrm{L}$ were incubated at $37^{\circ} \mathrm{C}$ for $30 \mathrm{~min}$ with an equal volume of sialidase reagent with or without $0.2 \%$ Triton X-100 (detergent) [80]. The samples were centrifuged at $10,000 \mathrm{rpm}$ for $5 \mathrm{~min}$ and the supernatant used to measure the sialic acid released using a combination of the methods of Warren et al. [81] and Aminoff et al. [82]. Briefly, $0.5 \mathrm{ml}$ of sample / standard was incubated at $37^{\circ} \mathrm{C}$ with $0.25 \mathrm{ml}$ of the periodate reagent for $30 \mathrm{~min}$. At the end of $30 \mathrm{~min}$, the tubes were taken out of water bath and $0.2 \mathrm{ml}$ of sodium arsenite solution was added to reduce the excess periodate. The tubes were then vortexed until the yellow color of the liberated iodine disappeared (2 min). As soon as the yellow color disappeared, $2 \mathrm{ml}$ of thiobarbituric acid reagent was added, tubes were capped, vortexed and placed in a boiling water bath for 10 min. At the end of $10 \mathrm{~min}$, the tubes were placed in ice water for $5 \mathrm{~min}$ and then shaken 
with $3 \mathrm{ml}$ of cyclohexanone. The tubes were then centrifuged at $3000 \mathrm{rpm}$ for $3 \mathrm{~min}$ and the upper organic layer collected. The organic layer was transferred to a cuvette and the absorbance was measured at $549 \mathrm{~nm}$ using a Hitachi U-2000 UV spectrophotometer. The amount of sialic acid released in the samples was calculated from the slope of the standard curve generated using N-acetylneuraminic acid $(20 \mu \mathrm{g} / \mathrm{ml}-320 \mu \mathrm{g} / \mathrm{ml})$.

\section{Calculations}

$\%$ Inside - OutVesicles $=100-\left(\left[\frac{\text { SialicAcid } \text { Released }(-\operatorname{det} \text { ergent })}{\text { SialicAcid } \text { Released }(+\operatorname{det} \text { ergent })}\right] \times 100\right)$

\section{Periodate Reagent}

Periodate reagent consists of $0.2 \mathrm{M}$ sodium $m$-periodate, $9 \mathrm{M}$ phosphoric acid.

Dissolve sodium $m$-periodate in water first and then add the phosphoric acid.

Store at room temperature.

\section{Sodium arsenite reagent:}

Sodium arsenite reagent consists of $0.5 \mathrm{M}$ sodium sulfate, $0.1 \mathrm{M} \mathrm{H}_{2} \mathrm{SO}_{4}$ and $10 \%$ sodium arsenite.

Store at room temperature.

\section{Thiobarbituric acid reagent:}

Thiobarbituric acid reagent consists of $0.1 \mathrm{M}$ thiobarbituric acid with the $\mathrm{pH}$ adjusted to pH 9.0 with $10 \mathrm{~N} \mathrm{NaOH}$.

Store at $4^{\circ} \mathrm{C}$ in a refrigerator.

\section{Sialidase Stock:}


Type VI neuraminidase from Clostridium perfringens (Sigma) is stored as $1 \mathrm{mg} / \mathrm{ml}$ solution in $0.3 \mathrm{mg} / \mathrm{ml}$ bovine serum albumin in refrigerator.

\section{Sialidase Reagent:}

$0.1 \mathrm{mg} / \mathrm{ml}$ of sialidase in $0.1 \mathrm{M}$ Tris-acetate buffer $\mathrm{pH}$ 5.0. Store in refrigerator.

\section{Sialidase and Triton reagent:}

Sialidase reagent $+0.2 \%(\mathrm{v} / \mathrm{v})$ Triton $\mathrm{X}-100$. Store in refrigerator.

\subsection{Alkaline Phosphatase Assay}

Alkaline phosphatase is a marker enzyme localized in the microvillus membrane of cells. It catalyzes the formation of $p$-nitrophenol from $p$-nitrophenylphosphate [83]. An alkaline phosphatase assay can be used to determine the enrichment of microvillus membrane when isolating membranes from cells or tissue homogenates [79] as well as to measure the orientation of membrane vesicles.

\subsubsection{For determination of enrichment of the microvillus membrane}

To determine the enrichment of the microvillus membrane, aliquots from various stages of the membrane vesicle preparation procedure were saved including homogenate 1, supernatant 1 , homogenate 2 and the final microvillus membrane pellet. The protein concentration of these samples was determined using the BCA protein assay. All the above mentioned fractions and the final microvillus membrane pellet were diluted to achieve a protein concentration of $2.5 \mathrm{mg} / \mathrm{ml}$ and further diluted to $1: 2000$ with 
diethanolamine $/ \mathrm{MgCl}_{2}$ buffer. $20 \mu \mathrm{L}$ of the diluted samples were aliquoted into a 96 well plate and to this $50 \mu \mathrm{L}$ of diethanolamine $/ \mathrm{MgCl}_{2}$ buffer containing $5 \mathrm{mM} p$ nitrophenylphosphate were added. After mixing, the plate was incubated at $37^{\circ} \mathrm{C}$ for 30 min and the absorbance read at $405 \mathrm{~nm}$ using a Thermomax plate reader. The amount of $p$-nitrophenol formed was calculated from a standard curve generated using $p$-nitrophenol $(40 \mu \mathrm{M}-1280 \mu \mathrm{M})$ dissolved in diethanolamine $/ \mathrm{MgCl}_{2}$ buffer. The fold enrichment in the final microvillus membrane pellet was calculated relative to the formation of $p$ nitrophenol in the homogenate 1 sample.

\subsubsection{For determination of orientation of vesicles}

Membrane vesicle samples were diluted to 1:10,000 with diethanolamine / $\mathrm{MgCl}_{2}$ buffer with or without $0.2 \%$ Triton X-100 (detergent). The alkaline phosphatase activity was measured as mentioned above. The percentage of inside-out vesicles was calculated from the following equation.

$\%$ Inside - OutVesicles $=100-\left(\left[\frac{p-\text { nitrophenolFormed }(- \text { det } \text { ergent })}{p-\text { nitrophenolFormed }(+\operatorname{det} \text { ergent })}\right] \times 100\right)$

\section{Diethonolamine / $\mathrm{MgCl}_{2}$ buffer ( $\mathrm{pH} 9.8$ )}

Diethonolamine $/ \mathrm{MgCl}_{2}$ buffer consists of $1 \mathrm{M}$ diethanolamine and $0.24 \mathrm{mM}$ Magnesium chloride hexahydrate.

Dissolve magnesium chloride in half the volume of water first and then add the diethanolamine and adjust the $\mathrm{pH}$ to 9.8 with $\mathrm{HCl}$. Store at $4^{\circ} \mathrm{C}$. 


\subsection{Uptake Assay: Developmental Work and Final Protocol}

Since P-glycoprotein and ABCP are efflux transporters, membrane vesicles with inside-out orientation are useful in measuring the accumulation of radiolabeled substrate. The active uptake is determined by measuring the uptake in the presence and absence of ATP. By measuring the time and osmotic dependent uptake we can distinguish between the actual uptake of the substrate across the membrane and non-specific binding of substrate to the membrane [84]. Vinblastine and mitoxantrone were used as model substrates for determining the activity of P-gp and $\mathrm{ABCP}$, respectively.

Membrane vesicles were diluted using the vesicle dilution buffer to a concentration of $2.5 \mathrm{mg} / \mathrm{ml}$. After dilution, the vesicles were syringed 10 times using a 25 -gauge needle. Forty-five $\mu \mathrm{L}$ of transport buffer (with or without ATP) containing substrate and an ATP regenerating system was aliquoted into glass test tubes and maintained at $37^{\circ} \mathrm{C}$. The diluted vesicles were also placed in a water bath at $37^{\circ} \mathrm{C}$. Following a 5 min pre-incubation, the reaction was initiated by addition of $10 \mu \mathrm{L}$ of diluted vesicles to each tube at $30 \mathrm{sec}$ intervals. At the end of the incubation period (10 min for vinblastine and 6 min for mitoxantrone), the reaction was quenched by addition of $3 \mathrm{ml}$ of ice-cold quench buffer. The quenched samples were immediately filtered through $0.45 \mu \mathrm{m}$ nitrocellulose filters (Whatman), pre-soaked in $3 \%$ bovine serum albumin, using a Millipore 1225 Sampling Manifold. The filters were then washed with an additional $3 \mathrm{ml}$ of ice-cold quench buffer and then transferred with forceps to a scintillation vial. Ten $\mathrm{ml}$ of Scintiverse ${ }^{\circledR}$ BD was added and the vials were shaken. They were allowed to sit for a few minutes before the samples were read using a 
Beckman scintillation counter. The cpm obtained from the instrument were then used in the following equation to calculate the uptake as pmol $/ \mathrm{mg}$ of protein. The ATP dependent uptake was the difference between the uptake in the presence and absence of ATP.

$$
\text { pmolof }\left[{ }^{3} H\right]-\text { substrate } / \text { mgofprotein }=\left(\frac{C P M \times \text { pmolofSubstrateAdded }}{\text { TotalCPMAdded } \times \text { mgofprotein }}\right)
$$

\section{Buffer 2}

Buffer 2 consists of $10 \mathrm{mM}$ Tris-HCl, $\mathrm{pH} 7.4$ and $250 \mathrm{mM}$ sucrose.

\section{Transport buffer}

Transport buffer consists of $10 \mathrm{mM}$ creatine phosphate, $100 \mu \mathrm{g} / \mathrm{ml}$ creatine phosphokinase, $10 \mathrm{mM}$ magnesium chloride hexahydrate and $4 \mathrm{mM}$ ATP (added only in + ATP transport buffer). The volume was made up with buffer 2 .

For vinblastine uptake assay:

$20 \mathrm{nM}\left[{ }^{3} \mathrm{H}\right]$-vinblastine (stock of $\left.0.25 \mu \mathrm{Ci} / \mu \mathrm{L}\right)+$ enough cold vinblastine $(5 \mu \mathrm{M}$ stock in buffer 2) to make a final concentration of $100 \mathrm{nM}$.

For mitoxantrone uptake assay;

$50 \mathrm{nM}\left[{ }^{3} \mathrm{H}\right]$-mitoxantrone (stock of $\left.1 \mu \mathrm{Ci} / \mathrm{ml}\right)+$ enough cold mitoxantrone $(5 \mu \mathrm{M}$ stock in buffer 2) to make a final concentration of $100 \mathrm{nM}$.

\section{Vesicle dilution buffer:}

Vesicle dilution buffer consists of $10 \mathrm{mM}$ creatine phosphate, $100 \mu \mathrm{g} / \mathrm{ml}$ creatine phosphokinase and $10 \mathrm{mM}$ magnesium chloride hexahydrate. The volume was made up with buffer 2 .

Quench buffer: Ice-cold buffer 2 


\subsubsection{Time Dependent Uptake Assay}

For determining the time course of the reaction, the membrane vesicles were incubated with vinblastine in transport buffer as outlined above and the reaction was quenched at $0,1,2,4,6,8,10,15,20,30$ and $60 \mathrm{~min}$. The uptake was measured in the presence and absence of ATP.

\subsubsection{Osmotic Dependent Uptake Assay}

To determine whether the uptake was sensitive to osmolarity changes, increasing concentrations of sucrose were added to the transport buffer. The transport buffer contained $250 \mathrm{mM}, 333 \mathrm{mM}, 500 \mathrm{mM}$ and $1 \mathrm{M}$ sucrose with rest of the additives remaining the same. Vinblastine uptake was measured in the presence and absence of ATP for $10 \mathrm{~min}$ in triplicate. The remainder of the procedure was followed as outlined above in the uptake protocol.

\subsubsection{Determination of type of filters and filter soaking media to block the non-specific binding}

Two different types of filters, nitrocellulose $(0.45 \mu \mathrm{m})$ and glass fiber filters (GF / F), were used with different types of soaking media: 10\% fetal bovine serum, $3 \%$ bovine serum albumin, $5 \mu \mathrm{M}$ unlabeled vinblastine (for 5 min and $1 \mathrm{~h}$ ). Also, $1 \mu \mathrm{M}$ and $10 \mu \mathrm{M}$ unlabeled vinblastine was used in the quench media to determine if it would decrease the non-specific binding of $\left[{ }^{3} \mathrm{H}\right]$-vinblastine to the filters. 


\subsubsection{Inhibition studies}

The uptake assay was carried out in the presence of inhibitors of P-gp and ABCP to assess the involvement of the transporters in the uptake of vinblastine and mitoxantrone, respectively. Inhibition studies were also carried out to determine if either protein interfered with the transport of the model substrate of the other protein.

The mitoxantrone uptake assay was carried out in presence of $10 \mu \mathrm{M}$ fumitremorgin $\mathrm{C}$ (FTC), a selective inhibitor of $\mathrm{ABCP}$ [44] and $10 \mu \mathrm{M}$ of verapamil, a known P-gp inhibitor. Likewise, uptake of vinblastine was determined in presence of verapamil $(10 \mu \mathrm{M}$ and $100 \mu \mathrm{M})$ and $10 \mu \mathrm{M}$ FTC.

\subsection{Immunoblotting Studies for Detection of P-gp and ABCP}

Placental membrane vesicles were added to a volume of loading buffer to achieve a concentration of $2 \mu \mathrm{g} / \mu \mathrm{L}$. The broad range molecular weight markers (Bio-Rad) and samples were boiled for $10 \mathrm{~min}$ and $10 \mu \mathrm{g}$ of protein (sample) was loaded on 15 well 7\% NuPAGE Tris-acetate mini gels (Invitrogen). Electrophoresis was carried out using a Surelock mini cell apparatus (Invitrogen) for $1 \mathrm{~h} 30 \mathrm{~min}$ at 130 volts. Proteins were then transferred to a nitrocellulose membrane for $1 \mathrm{~h} 30 \mathrm{~min}$ at $30 \mathrm{mV}$ on ice. The membrane was then stained with Ponceu S stain (Sigma) to confirm the transfer of the proteins and to mark the molecular weight markers. The membrane was then blocked with $50 \mathrm{ml}$ of blocking buffer and shaken for $1 \mathrm{~h}$ at room temperature. The membrane was then probed with P-gp antibody C-219 or with ABCP antibody BXP-21 (Signet Laboratories). The 
primary antibody was diluted to 1:1000 in antibody dilution buffer and allowed to react with the membrane overnight at $4^{\circ} \mathrm{C}$ on a shaker. Then next day the membrane was warmed to room temperature for 30 min prior to washing 4 times with wash buffer $(10,5$, 5 and $5 \mathrm{~min}$ ). A secondary antibody, horseradish peroxidase (HRP) linked sheep antimouse antibody (1:5000, KPL Labs), was applied for $1 \mathrm{~h}$ at room temperature. The membrane was again washed 4 times as earlier and the protein bands were detected using the enhanced chemiluminescence (ECL) detection reagents (Amersham Pharmacia Biotech). The two ECL reagents (4 $\mathrm{ml}$ each) were mixed and poured over the membrane for $1 \mathrm{~min}$. The membrane was subsequently sandwiched between 2 transparency sheets and placed in a Hyperfilm cassette (Amersham Pharmacia Biotech). The X-ray films were then exposed to the membrane for various time intervals and the film was developed using an X-ray film developer. The relative amounts of P-gp and ABCP were determined by density measurements made using Optimas Imaging software (Media Cybernetics, Silverspring, MD) and reported as optical density (O.D.) values.

Though equal amounts of protein were loaded per lane, the data was normalized with actin protein to take into account if there were any differences in protein load. The membranes which were probed for P-gp and ABCP were washed with wash buffer and stripped using stripping buffer. The stripped membranes were then probed with antiactin antibody (1:200; SantaCruz) followed with (HRP) linked human anti-goat antibody (1:2000; SantaCruz). The remainder of procedure was followed as outlined above. 
Stocks of sample buffer (NP0007), running buffer (LA0041) and transfer buffer (NP0006) were purchased from Invitrogen and buffers were prepared according to manufacturer's directions. All the buffers were prepared fresh on the day of experiment.

10X TBS: 1 pack of TBS (BupH Tris Buffererd Saline packs (Pierce); $25 \mathrm{mM}$ Tris, 0.15 $\mathrm{M}$ sodium chloride, $\mathrm{pH} 7.2$ when pouch contents dissolved in a final volume of $500 \mathrm{ml}$ $\mathrm{dH}_{2} \mathrm{O}$ ) dissolved in $50 \mathrm{ml}$ of distilled water.

TBS 1X: 2 packs of TBS in 1 liter of distilled water.

Blocking buffer: $5 \%$ milk in Tris-buffered saline (TBS)

To $5 \mathrm{ml}$ TBS $10 \mathrm{X}$ add $2.5 \mathrm{gm}$ non-fat dry milk and q.s. to $50 \mathrm{ml}$ with distilled water.

Antibody dilution buffer: $1 \%$ milk in $0.5 \%$ Tween 20 and TBS

To $20 \mathrm{ml}$ of TBS $10 \mathrm{X}$ add $2 \mathrm{gm}$ of non-fat dry milk and $0.1 \mathrm{ml}$ of Tween 20 and then q.s. to $200 \mathrm{ml}$ with distilled water.

Wash buffer: $0.1 \%$ Tween 20 in TBS

Add $1 \mathrm{ml}$ Tween 20 to 1 liter of TBS $1 \mathrm{X}$.

Stripping buffer:

Stripping buffer consists of $7 \mathrm{M}$ guanidine $\mathrm{HCl}, 0.05 \mathrm{mM}$ EDTA, $0.1 \mathrm{M}$ potassium chloride, $20 \mathrm{mM}$ of $\beta$-mercaptoethanol, $50 \mathrm{mM}$ glycine and distilled water to make up the volume. 


\subsection{Preparation of Placental Microsomes}

Placental microsomes were prepared according to the methods of Vaz et al. [85] Briefly, tissues were removed from the $-80^{\circ} \mathrm{C}$ freezer and allowed to thaw on ice in $1 \%$ $\mathrm{KCl}$. All steps were carried out at $4^{\circ} \mathrm{C}$ (on ice) or in a refrigerated centrifuge. After removal of the chorionic plate, the tissue was cut into small pieces and washed several times with $1 \% \mathrm{KCl}$ to remove excess blood. The tissue was then finely minced using scissors. To this minced tissue, homogenization buffer was added ( $4 \mathrm{ml} / \mathrm{gm}$ of tissue). Aliquots of tissue were then disrupted with a Virtishear tissue homogenizer for $1 \mathrm{~min}$ and transferred to a Potter-Elvejehem vessel and homogenized by five passes with a pestle. The homogenized tissue suspension was then centrifuged in a refrigerated Sorvall RC 5B $\left(\right.$ Rotor $=\mathrm{SA} 600$ ) in $50 \mathrm{ml}$ tubes at $10,000 \mathrm{rpm}$ at $4^{\circ} \mathrm{C}$ for $20 \mathrm{~min}$. The supernatant was

transferred to clean ultracentrifuge tubes and centrifuged in a Beckman Coulter Optima ${ }^{\mathrm{TM}}$ LE-80K Ultracentrifuge (Rotor $=\mathrm{Ti} 70.1$ ) at $100,000 \mathrm{~g}$ and $4^{\circ} \mathrm{C}$ for $60 \mathrm{~min}$. The supernatant was discarded and wash buffer (same volume as homogenization buffer) was added to the pellet. The pellets were resuspended using a glass stirring rod and centrifuged again for $60 \mathrm{~min}$ at $100,000 \mathrm{~g}$ as above. The supernatant was discarded and the pellets were resuspended in storage buffer ( $1 \mathrm{ml}$ per $5 \mathrm{gm}$ of starting tissue), then transferred to a $5 \mathrm{ml}$ Potter-Elvejehem tube and homogenized by 3 passes of a pestle. The suspended microsomes were then aliquoted in labeled microcentrifuge tubes and stored at $-80^{\circ} \mathrm{C}$. The protein concentration was determined using BCA protein assay kit as described earlier. 
$\underline{\text { KP Stock Buffer (1 M) }}$

$\mathrm{K}_{2} \mathrm{HPO}_{4} \quad 190.71 \mathrm{~g}$

$\mathrm{KH}_{2} \mathrm{PO}_{4}$

q.s. to 1 liter with distilled water.

Homogenization Buffer (pH 7.5)

Homogenization buffer consists of $0.15 \mathrm{M} \mathrm{KCl}$ and $0.25 \mathrm{M} \mathrm{KP}$ buffer

The buffer was made up to volume with distilled water and $\mathrm{pH}$ was adjusted to 7.5 with $\mathrm{H}_{3} \mathrm{PO}_{4}$. PMSF $(1 \mathrm{mM})$ was added from $100 \mathrm{mM}$ stock in absolute ethanol just before use.

\section{$\underline{\text { Wash Buffer (pH 7.5) }}$}

Wash buffer consists of $0.1 \mathrm{M}$ sodium pyrophosphate and $1 \mathrm{mM}$ EDTA (disodium salt, dihydrate). The volume was made up with distilled water and $\mathrm{pH}$ was adjusted to 7.5.

\section{Microsomal Storage Buffer ( $\mathrm{pH} 7.25)$}

Microsomal storage buffer consists of $100 \mathrm{mM} \mathrm{KP}$ buffer, $1 \mathrm{mM}$ EDTA (disodium salt, dihydrate), $20 \%$ glycerol, $1 \mathrm{mM}$ dithiothreitol and $20 \mu \mathrm{M}$ butylated hydroxytoluene. The volume was made up with distilled water and $\mathrm{pH}$ was adjusted to 7.25

\subsection{Ethoxyresorufin- $O$-deethylation Assay for CYP1A1}

7-ethoxyresorufin-O-deethylation (EROD) activity catalyzed by CYP1A was determined in placental microsomes according to the methods of Burke et al. [86] with slight modifications. Briefly, a $1.25 \mathrm{ml}$ incubation mixture contained Na-K phosphate 
buffer ( $0.1 \mathrm{M}, \mathrm{pH} 7.6), 0.5 \mathrm{mg} / \mathrm{ml}$ of microsomal protein and $20 \mu \mathrm{M}$ of 7-ethoxyresorufin (2 $\mathrm{mM}$ stock in DMSO). Following a one minute pre-incubation at $37^{\circ} \mathrm{C}, 1 \mathrm{ml}$ of the reaction mixture was transferred to a quartz cuvette and autozero was set on the spectrofluorometer. The reaction was initiated by addition of $1 \mathrm{mM}$ NADPH (freshly prepared $20 \mathrm{mM}$ stock in water) and the cuvette was inverted to ensure thorough mixing. Relative fluorescence intensity was measured using a Shimadzu RF-5301 PC spectroflurometer with excitation and emission wavelengths of $530 \mathrm{~nm}$ and $585 \mathrm{~nm}$ respectively. The spectrofluorometer was maintained at $37^{\circ} \mathrm{C}$. Relative fluorescence intensity was measured for 10 min to determine the linear range which was found to be $0.5 \mathrm{~min}$ to $3 \mathrm{~min}$ at $37^{\circ} \mathrm{C}$. The amount of resorufin formed from 7-ethoxyresorufin was determined using a standard curve for resorufin and activity was calculated from the equation given below and reported as $\mathrm{pmol} / \mathrm{min} / \mathrm{mg}$ of protein.

$\mathrm{pmol} / \mathrm{min} /$ mgofprotein $=\left(\frac{\text { AmountFormedAt } 3 \mathrm{~min}-\text { AmountFormedAt } 0.5 \mathrm{~min}}{2.5 \mathrm{~min} \times 0.5 \mathrm{mgofprotein}}\right)$

\section{$\underline{\text { Sodium Potassium Phosphate Buffer }}$}

Sodium phosphate buffer consists of $0.1 \mathrm{M} \mathrm{Na}_{2} \mathrm{HPO}_{4}, 0.1 \mathrm{M} \mathrm{KH}_{2} \mathrm{PO}_{4}, 2.5 \mathrm{mM} \mathrm{MgCl} 2$ and $0.1 \mathrm{M} \mathrm{KCl}$. Make up the volume with distilled water and adjust the $\mathrm{pH}$ to 7.6. 


\subsection{Cell Culture}

The JAR and BeWo, placental choriocarcinoma cell lines was obtained from American Type Culture Collection (ATCC). These cell lines were used to study the induction of placental P-gp after treatment with known inducers of P-gp.

\section{Cell Culture Media - Bewo cell line}

To Ham's F12K media add sodium bicarbonate to get $1.5 \mathrm{~g} / \mathrm{L}$ and $10 \%$ of fetal bovine serum. Mix all the above ingredients outside the cell culture hood and then filter aseptically.

Store at $4^{\circ} \mathrm{C}$ till use

\section{Cell Culture Media - JAR cell line}

RPMI 1640 media with $2 \mathrm{mM}$ L-glutamine was adjusted to contain $1.5 \mathrm{~g} / \mathrm{L}$ sodium bicarbonate, $4.5 \mathrm{~g} / \mathrm{L}$ of glucose and $10 \mathrm{mM}$ of Hepes. To this add $10 \%$ of fetal bovine serum.

Mix all the above ingredients outside the cell culture hood and then filter aseptically. To this sterile media add the following sterile products aseptically.

$1.0 \mathrm{mM}$ of sodium pyruvate, $5 \mathrm{ml}$ of Penicillin / streptomycin solution (10,000 units/ml of penicillin $\mathrm{G}$ sodium and $10,000 \mu \mathrm{g} / \mathrm{ml}$ of streptomycin sulfate in $0.85 \%$ saline).

Mix well and store at $4^{\circ} \mathrm{C}$ till use.

\section{Starting a new culture}

The cell culture media was warmed at $37^{\circ} \mathrm{C}$. A frozen vial of cells was removed from the liquid nitrogen freezer and kept on ice. The vial was rapidly thawed at $37^{\circ} \mathrm{C}$ (within $2 \mathrm{~min}$ ) and $1 \mathrm{ml}$ of the cell suspension was transferred to a $75 \mathrm{~cm}^{2}$ cell culture flask containing $20 \mathrm{ml}$ of warmed cell culture media. The flask was then stored in a 
incubator at $37^{\circ} \mathrm{C}$ and $5 \% \mathrm{CO}_{2}$. The medium was changed every other day and cells were subcultured every 4-5 days at the ratio of 1:8 for BeWo cells and 1:15 for JAR cells.

\section{Subculturing procedure}

Cell culture media, phosphate buffered saline (PBS) and trypsin containing $0.01 \%$ EDTA (aliquoted as $5 \mathrm{ml}$ ) were warmed at $37^{\circ} \mathrm{C}$. The media from the flask was aspirated out and cells were washed with $10 \mathrm{ml}$ of PBS twice. After aspirating the PBS, $5 \mathrm{ml}$ of trypsin was added and the flask was transferred to the incubator for $5 \mathrm{~min}$. After $5 \mathrm{~min}$ the flask was gently tapped to loosen the cells from the surface of the flask. Fifteen $\mathrm{ml}$ of media was added and the cell suspension was pipetted up and down to obtain a single cell suspension. The cells were then split at the ratio of 1:8 (BeWo cells) or 1:15 (Jar cells) into a new flask as well as 6 well plates which were used for induction studies.

\subsubsection{Induction studies}

The cells were plated in 6 well culture plates. At $50 \%$ confluency of cells, the cells were treated with drugs dissolved in DMSO or appropriate solvent. The JAR cells were treated with $10 \mu \mathrm{M}$ rifampin, $10 \mu \mathrm{M}$ clotriamazole, $0.1,1,5,10$ and $25 \mu \mathrm{M} 3$ methyl cholanthrene (3-MC) dissolved in DMSO or 10 and $50 \mu \mathrm{M}$ benzo-[a]-pyrene dissolved in acetone. The cells were also treated with appropriate vehicle controls. BeWo cells were treated with 10 and $25 \mu \mathrm{M}$ rifampin and DMSO as solvent control. At the end of $72 \mathrm{~h}$, the media was aspirated and cells were washed twice with PBS nonaseptically. The cells were then kept on ice and $300 \mu \mathrm{L}$ of lysis buffer was added. The 
plate was shaken periodically for $10-15$ min on ice. With a help of a cell scraper or rubber policeman, the lysed cells were scraped and transferred to an appropriately labeled $1.5 \mathrm{ml}$ microcentrifuge tube. The cell lysate was then sonicated on ice for $10 \mathrm{sec}$ (x 3) using a sonicator tip. The cell lysate was aliquoted and stored at $-80^{\circ} \mathrm{C}$. Protein content was determined using the BCA assay kit as described earlier. Immunoblotting studies (as outlined above) were carried out on these cell lysates to determine if P-gp was induced in these treated cells.

Lysis buffer

Lysis buffer consists of $50 \mathrm{mM}$ Tris-HCl, pH 7.0, 1.0\% Triton X-100, 1 mM PMSF (100 $\mathrm{mM}$ stock in absolute ethanol), $10 \mu \mathrm{g} / \mathrm{ml}$ leupeptin and $20 \mu \mathrm{g} / \mathrm{ml}$ aprotinin. 
CHAPTER - III

\section{EVALUATION OF P-GLYCOPROTEIN AND ABCP EXPRESSION AND FUNCTION IN HUMAN PLACENTAL TISSUE FROM SMOKERS AND NON-SMOKERS}




\subsection{Introduction}

P-glycoprotein (P-gp), encoded by the $A B C B 1$ (MDR1; multidrug resistance) gene, is an efflux transporter that pumps xenobiotics out of cells, utilizing ATP as the energy source. P-gp is present in various normal tissues [9] like intestine, liver and kidney where it plays an important role in absorption, distribution and excretion of drugs [87]. In addition, P-gp also plays a role in the transport of xenobiotics across the blood brain barrier, modulating their CNS effects [88]. Another tissue in which P-gp regulates xenobiotic transfer is the placenta. Studies in $m d r$ knock-out mice have demonstrated that placental P-gp can affect the transfer of xenobiotics across the placental barrier [10;13], suggestive of a role in protecting the fetus from drugs ingested by the mother during pregnancy or environmental toxicants.

Polycyclic aromatic hydrocarbons (PAH) are primary constituents of cigarette smoke and can be classified as environmental toxicants. Cigarette smoking has been associated with adverse outcomes during pregnancy including changes in function and structure of the placenta. Furthermore, maternal smoking has been associated with increased fetal morbidity and mortality. Smoking and the associated PAHs can affect drug metabolizing enzymes and increase levels of cytochrome P450 1A1 (CYP1A1) in human placenta [62]. However, the effect of smoking on drug efflux transporters expressed in placenta is not known. In-vitro studies using rat [76], mouse [77] and human hepatocytes [17], have demonstrated that P-gp mRNA was induced by 3methlycholanthrene (3-MC), a PAH. In addition, the PAH benzo[a]pyrene, which is a substrate of CYP1A1, is also transported by P-gp [78]. Thus, analogous to CYP1A1 
induction, there could possibly be induction of P-gp in placentas of women who smoke during pregnancy. Based on these lines of evidence, we hypothesized that smoking might increase P-gp levels in human placenta.

In addition, we also studied the expression and function of $\mathrm{ABCP}$ which is a recently discovered protein belonging to the $\mathrm{ABC}$ superfamily of proteins. $\mathrm{ABCP}$ [36], also known as MXR [38] or BCRP [37], is a $70 \mathrm{kDa}$ protein encoded by $A B C G 2$ and is also involved in the active efflux of drugs. It is expressed at high levels in placenta, liver and small intestine and lower expression is seen in kidney, heart and brain [38;49]. Studies in mdr knock-out mice have shown that there was increased placental transfer of topotecan in $m d r$ knock-out mice in the presence of GF120918, an ABCP inhibitor, as compared to without GF120918 [51]. This suggests a protective role of ABCP, similar to P-gp, in the placenta.

To study the effect of smoking on function and expression of both these proteins, placentas were collected from smokers and non-smokers and membrane vesicles isolated. In addition, since CYP1A1 activity is induced by smoking [62], CYP1A1 activity was also measured in human placental microsomes as a positive control for the effect of smoking. 


\subsection{Methods}

Materials. $\left[{ }^{3} \mathrm{H}\right]$-vinblastine $(10.9 \mathrm{Ci} / \mathrm{mmol})$ and $\left[{ }^{3} \mathrm{H}\right]$-mitoxantrone $(3 \mathrm{Ci} / \mathrm{mmol})$ were purchased from Amersham Biosciences (Piscataway, NJ) and American Radiolabeled Chemicals (St. Louis, MO) respectively. Verapamil, mitoxantrone, vinblastine, resorufin, 7-ethoxyresorufin, ATP, creatine phosphokinase, NADPH, EGTA, PMSF and bovine serum albumin were purchased from Sigma Chemical Co. (St. Louis, MO). Creatine phosphate was purchased from Fluka (Switzerland). Scintiverse ${ }^{\circledR}$ BD, magnesium chloride and EDTA were purchased from Fisher Co. (Pittsburgh, PA). Fumitremorgin C (FTC) was a gift from Dr. Susan Bates (NIH). All other chemicals were purchased from commercial sources and were of the highest purity available.

Tissue Collection. Human placental tissue was obtained under a protocol approved by the West Virginia University Institutional Review Board for the Protection of Human Research Subjects. Placentas were obtained from ten smokers and ten nonsmokers who had given written informed consent prior to obstetric delivery. Smoking status was assessed by patient interview. Placentas were collected and processed immediately after delivery. Two triangular wedges extending from center of the placenta to the placental margin were cut. One piece was frozen at $-80^{\circ} \mathrm{C}$ for later preparation of microsomes and the other piece was immediately processed to prepare the membrane vesicles. 
Preparation of Microvillus Membrane Vesicles. Microvillous membrane vesicles (MVM) were prepared according to the methods of Illsley et al. [79]. Briefly, the tissue was cut and washed in $0.9 \% \mathrm{NaCl}$. The washed tissue was further minced finely and suspended in 3 volumes of buffer containing $10 \mathrm{mM}$ Tris-Hepes (pH 7.0), 250 mM sucrose, 5 mM EGTA, 5 mM EDTA and 1 mM PMSF (buffer 1). This suspension was homogenized for $2 \mathrm{~min}$ and centrifuged at $10,000 \mathrm{~g}$ for $15 \mathrm{~min}$. The supernatant was collected and centrifuged at 47,500 g for $1 \mathrm{~h}$. The pellet was resuspended in buffer 1 and $\mathrm{MgCl}_{2}$ was added (12 mM final concentration). The mixture was stirred on ice for 20 min and centrifuged at $2500 \mathrm{~g}$ for $15 \mathrm{~min}$. The supernatant was again centrifuged at 47,500 $\mathrm{g}$ for $30 \mathrm{~min}$ to get the MVM pellet. This pellet was washed and resuspended in buffer 2 (10 mM Tris-HCl ( $\mathrm{pH} 7.4)$ and $250 \mathrm{mM}$ sucrose) using a 25-gauge needle through which the suspension was passed ten times. The vesicles were aliqouted and stored at $-80^{\circ} \mathrm{C}$. Protein concentration was determined by the BCA assay kit (Pierce). The percentage of inside-out vesicles was determined by sialidase accessibility [81] [82] and membrane vesicles were found to be $18-20 \%$ inside-out.

Uptake by Membrane Vesicles. ATP dependent transport of the radiolabeled substrate into membrane vesicles was measured by filtration using a 12 channel sampling manifold (Millipore. Corp., Bedford, MA). Transport buffer $(45 \mu \mathrm{L})$ containing $10 \mathrm{mM}$ Tris-HCl pH 7.4, $250 \mathrm{mM}$ sucrose, $10 \mathrm{mM} \mathrm{MgCl} 2,20 \mathrm{nM}\left[{ }^{3} \mathrm{H}\right]$-vinblastine (5000 cpm) or $50 \mathrm{nM}\left[{ }^{3} \mathrm{H}\right]$-mitoxantrone $(1300 \mathrm{cpm})$ and enough amount of respective unlabeled drug to produce a final concentration of $100 \mathrm{nM}$ and an ATP regenerating system consisting of $10 \mathrm{mM}$ phosphocreatine and $100 \mu \mathrm{g} / \mathrm{ml}$ creatine kinase were warmed at $37^{\circ} \mathrm{C}$ before 
initiating the reaction. Reactions were carried out in the presence or absence of $4 \mathrm{mM}$ ATP. The reaction was initiated by addition of $10 \mu \mathrm{L}$ of vesicle aliqout $(25 \mu \mathrm{g}$ of protein) and quenched after $10 \mathrm{~min}$ (vinblastine) or $6 \mathrm{~min}$ (mitoxantrone) with the addition of $3 \mathrm{ml}$ of ice-cold stop solution (10 mM Tris- $\mathrm{HCl} \mathrm{pH} 7.4$ and $250 \mathrm{mM}$ sucrose). The quenched reaction mixture was filtered immediately through nitrocellulose filters (0.45 $\mu \mathrm{m}$ Whatman) presoaked in 3\% BSA, and washed with an additional $3 \mathrm{ml}$ of icecold stop solution under light suction. The filters were then placed in a scintillation vial, Scintiverse ${ }^{\circledR}$ BD scintillant added, and radioactivity measured by liquid scintillation counting. ATP dependent uptake of radiolabeled substrate was calculated as the difference in the uptake of substrate measured in the presence and absence of ATP and reported as $\mathrm{pmol} / \mathrm{mg}$ of protein.

Immunoblotting for P-gp and ABCP. Membrane vesicle protein $(10 \mu \mathrm{g})$ was heated at $90^{\circ} \mathrm{C}$ for $10 \mathrm{~min}$ then loaded onto $7 \%$ Tris-acetate mini-gels (Invitrogen) and electrophoresed. The proteins were then transferred to a nitrocellulose membrane after which the membrane was blocked in blocking buffer $(5 \%$ non-fat dry milk in Tris buffered saline) for $1 \mathrm{~h}$ at room temperature and then incubated with C-219 P-gp antibody or BXP-21 ABCP antibody (1:1000, Signet Laboratories) overnight at $4^{\circ} \mathrm{C}$. The membrane was then washed with Tris buffered saline containing $0.1 \%$ Tween 20 (TTBS) and incubated with horseradish peroxidase linked sheep antimouse antibody (1:5000, KPL Labs) for $1 \mathrm{~h}$ at room temperature. After washing with TTBS, the blots were developed with an enhanced chemiluminescence detection system (Amersham Pharmacia Biotech). The relative amounts of P-gp and $\mathrm{ABCP}$ were determined by density 
measurements made using Optimas Imaging software (Media Cybernetics, Silverspring, MD) and reported as optical density (O.D.) values.

Measurement of CYP1A1 activity. Placental microsomes were prepared according to established methods [85]. Ethoxyresorufin- $O$-deethylation (EROD) activity catalyzed by CYP1A1 was determined as described by Burke et al. [86] with slight modifications. Briefly, $0.5 \mathrm{mg} / \mathrm{ml}$ of microsomal protein was incubated with $20 \mu \mathrm{M}$ of 7ethoxyresorufin (2 mM stock in DMSO) and Na-K phosphate buffer (0.1 M, pH 7.6) in a total volume of $1.25 \mathrm{ml}$ at $37^{\circ} \mathrm{C}$ for $1 \mathrm{~min}$. One $\mathrm{ml}$ of the reaction mixture was transferred to a cuvette and the reaction was initiated by addition of $1 \mathrm{mM}$ NADPH. Relative fluorescence intensity was monitored for 4 min using a Shimadzu RF-5301PC spectroflurometer at $37^{\circ} \mathrm{C}$ and set at excitation and emission wavelengths of $530 \mathrm{~nm}$ and $585 \mathrm{~nm}$, respectively. The rate of formation of resorufin from 7-ethoxyresorufin was calculated from a standard curve for resorufin and activity reported as $\mathrm{pmol} / \mathrm{min} / \mathrm{mg}$ of protein.

Statistical Analysis. Statistical comparisons of P-gp, ABCP and CYP1A1 activity as well as P-gp and $\mathrm{ABCP}$ expression between smokers and non-smokers were made using a one sided $t$ test. Statistical significance was set at $p<0.05$. 


\subsection{Results}

P-gp and ABCP expression in human placenta. A $170 \mathrm{kDa}$ P-gp protein was detected in all 20 samples of human placenta. However, substantial inter-individual variability in P-gp expression among the samples was noted (Figure 3.1). Statistical analysis showed that P-gp protein abundance was comparable between smokers and nonsmokers (Table 3.1). Similarly, an ABCP protein band was detected at $70 \mathrm{kDa}$, as reported by others, and its expression also was comparable between smokers and nonsmokers (Table 3.1).

Uptake of $\left[{ }^{3} \mathrm{H}\right]$-vinblastine in membrane vesicles (P-gp activity). ATP dependent transport of $\left[{ }^{3} \mathrm{H}\right]$-vinblastine was observed in membrane vesicles isolated from human placenta. This transport was also time dependent (data not shown). To determine whether the transport was truly intravesicular or just due to increased binding to P-gp in the presence of ATP, the effect of osmolarity on the transport of vinblastine by P-gp was studied. Figure 3.2 demonstrates that the transport observed was intravesicular as the uptake decreased with decreasing intravesicular volume resulting from increased osmolarity.

To determine if the vinblastine uptake was mediated by P-gp, uptake studies were carried out in the presence of verapamil, a known inhibitor of P-gp. ATP dependent vinblastine uptake was inhibited $42 \%$ by $10 \mu \mathrm{M}$ and $71 \%$ by $100 \mu \mathrm{M}$ verapamil (Figure 3.3), confirming the involvement of P-gp in vinblastine uptake. 


\section{Table 3-1 Expression of $P$-gp and ABCP in placental vesicles}

Optical density values (mean \pm S.D.) for P-gp and ABCP protein abundance in human placental tissue from smokers and non-smokers.

\begin{tabular}{|c|c|c|}
\hline $\begin{array}{c}\text { Densitometric analysis } \\
\text { (O.D. })\end{array}$ & $\begin{array}{c}\text { Smokers } \\
(\mathrm{n}=10)\end{array}$ & $\begin{array}{c}\text { Non-smokers } \\
(\mathrm{n}=10)\end{array}$ \\
\hline P-gp expression & $4.26 \pm 1.30$ & $3.88 \pm 2.28$ \\
\hline ABCP expression & $3.79 \pm 1.71$ & $2.81 \pm 1.04$ \\
\hline
\end{tabular}

O.D. $=$ optical density 


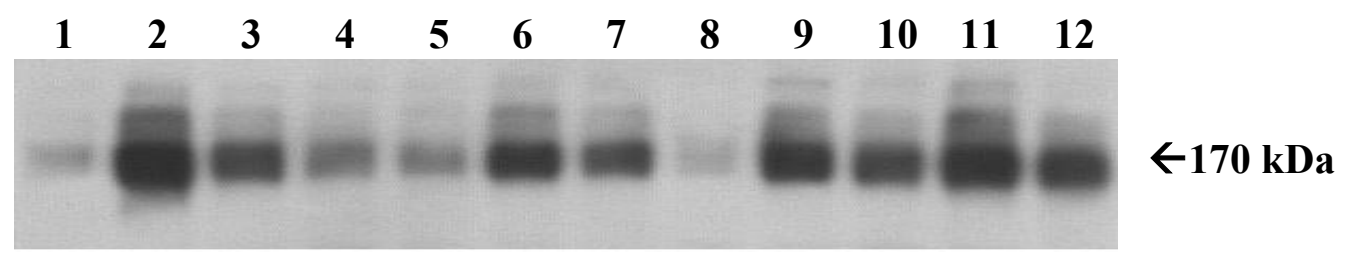

Figure 3-1 Representative immunoblot of $P$-gp in placental vesicles

Lanes 1, 3, 9, 11 and 12 are samples from smokers and lanes 2, 4, 5, 6, 7, 8 and 10 are samples from non-smokers. 


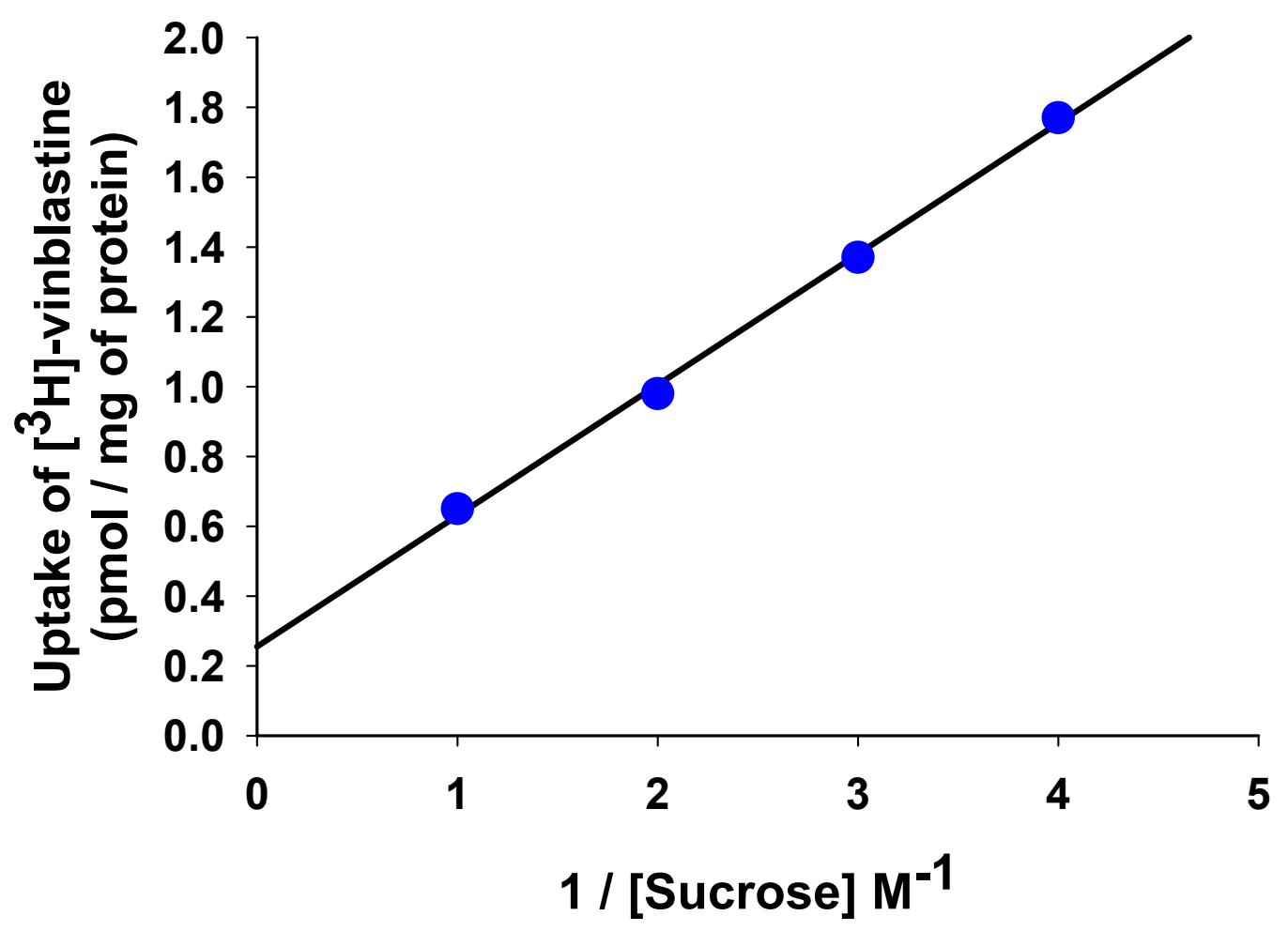

Figure 3-2 Effect of osmolarity on ATP dependent uptake of $\left[{ }^{3} \mathrm{H}\right]$-vinblastine in microvillus membrane vesicles.

Placental vesicles $(25 \mu \mathrm{g})$ were incubated for $10 \mathrm{~min}$ with $\left[{ }^{3} \mathrm{H}\right]$-vinblastine in the presence or absence of ATP $(4 \mathrm{mM})$ in transport buffer containing increasing concentrations of sucrose $(250,333,500$ and $1000 \mathrm{mM})$. Data represent the difference between the ATP dependent and independent uptake determined in triplicate samples. The coefficient of variation was less than $15 \%$ for each triplicate determination. 


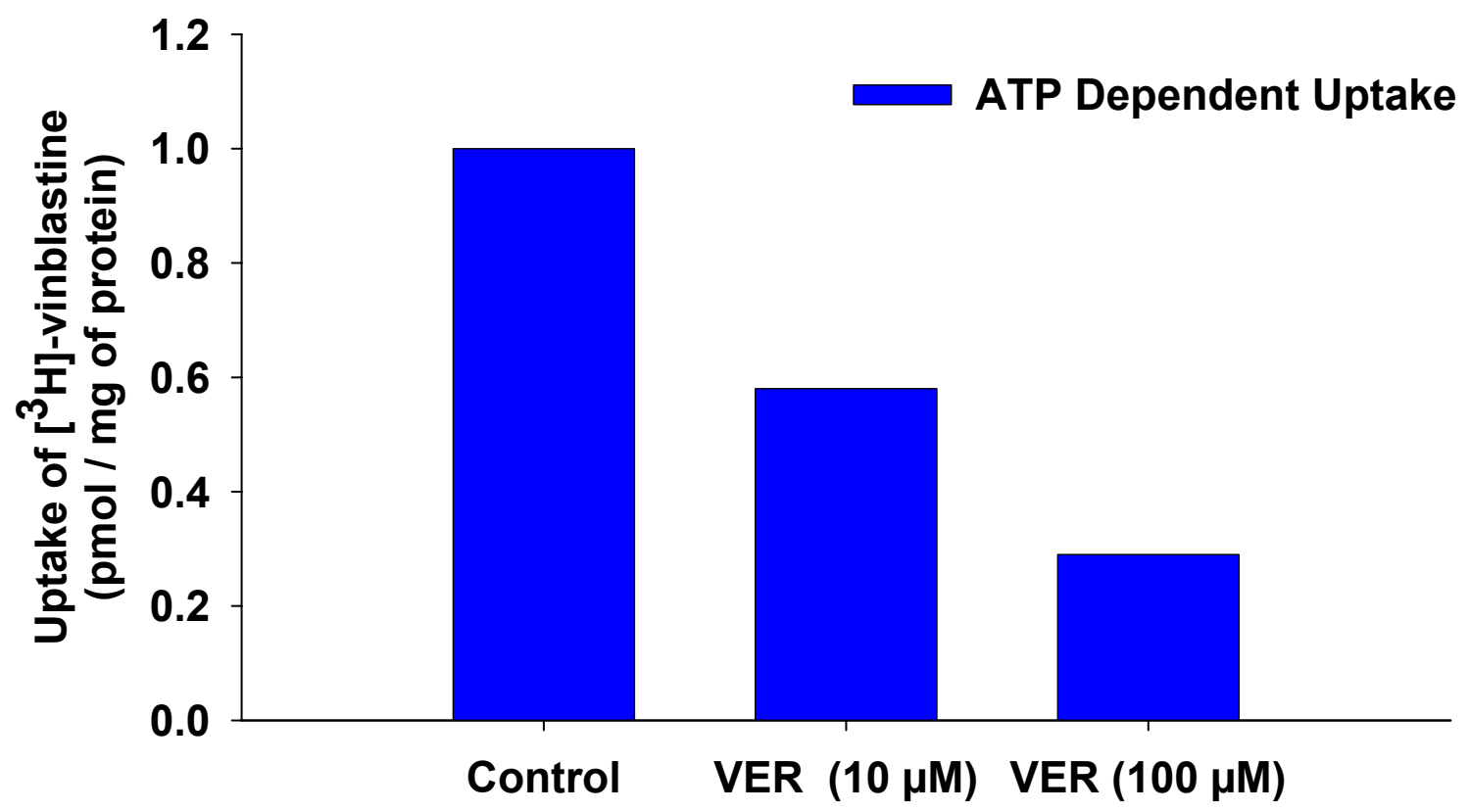

Figure 3-3 Effect of verapamil on ATP dependent uptake of vinblastine in microvillus membrane vesicles

Data represents the ATP dependent transport of vinblastine in absence (control) and presence of verapamil (VER $10 \mu \mathrm{M}$ and VER $100 \mu \mathrm{M}$ ). Mean of triplicate determinations with coefficient of variation less than $15 \%$ for all sets. 


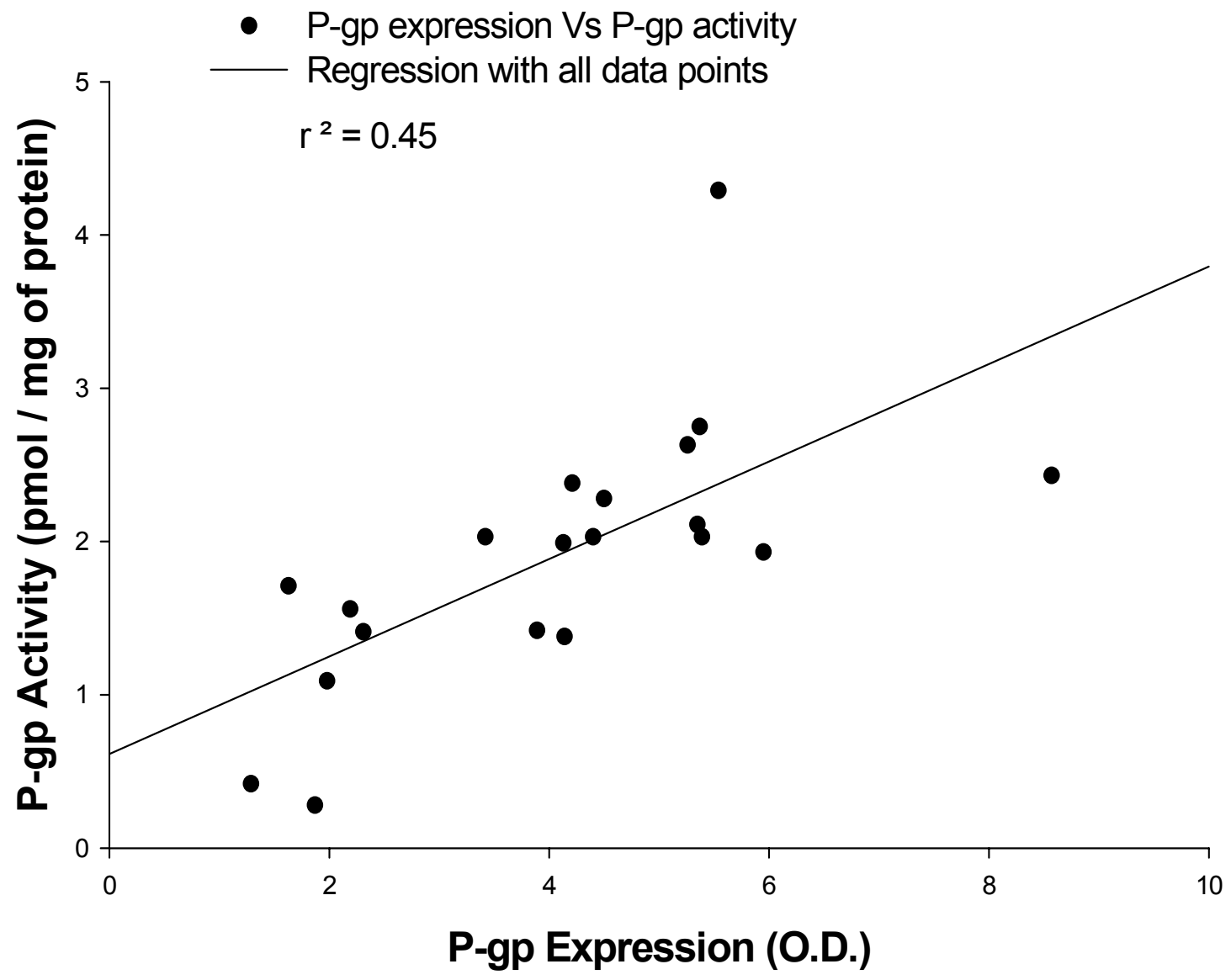

Figure 3-4 Correlation of P-gp activity with P-gp expression

On correlating P-gp activity with P-gp expression a positive correlation was seen with an $\mathrm{r}^{2}=0.45$ 
Placental P-gp activity, measured as the uptake of vinblastine, was not statistically different $(p>0.05)$ in smokers and non-smokers (Table 3.2). With respect to the correlation of P-gp expression and activity, a positive correlation, $\mathrm{r}^{2}=0.45$ was obtained (Figure 3.4).

Uptake of $\left[{ }^{3} \mathrm{H}\right]$-mitoxantrone in membrane vesicles (ABCP activity). ATP dependent transport of mitoxantrone was observed in membrane vesicles. To determine if this transport was mediated by $\mathrm{ABCP}$, mitoxantrone uptake was measured in the presence of fumitremorgin $\mathrm{C}$, a selective inhibitor of $\mathrm{ABCP}$ as well as verapamil, an inhibitor of P-gp. In the presence of $10 \mu \mathrm{M}$ fumitremorgin $\mathrm{C}$, a $65 \%$ inhibition of ATP dependent mitoxantrone transport was observed whereas $10 \mu \mathrm{M}$ verapamil had minimal effect (Figure 3.5). Placental ABCP activity, measured as the uptake of mitoxantrone, was not statistically different $(p>0.05)$ between smokers and non-smokers (Table 3.2). With respect to the correlation of $\mathrm{ABCP}$ expression and activity, a positive correlation, $\mathrm{r}^{2}$ $=0.25$ was obtained (Figure 3.6). However, on exclusion of one data point as an outlier a better correlation with $\mathrm{r}^{2}=0.74$ (Figure 3.6) was obtained.

$\mathrm{ABCP}$ is a half transporter and is thought to require dimerization to be active [89]. It has been demonstrated that in the absence of reducing agent, $\mathrm{ABCP}$ migrates as 140 $\mathrm{kDa}$ protein on electrophoretic gels [39]. We observed similar results on blots where $\mathrm{ABCP}$ migrated as a $140 \mathrm{kDa}$ protein under non-reducing conditions (in the absence of dithiothreitol, DTT) and as a $70 \mathrm{kDa}$ protein under reducing conditions (in the presence of DTT) (Figure 3.7). This suggests that $\mathrm{ABCP}$ exists as a dimer in non-reducing conditions and as a monomer under reducing conditions. In addition, we were also able 
to demonstrate for the first time that there was decreased transport of mitoxantrone by $\mathrm{ABCP}$ in presence of $1 \mathrm{mM}$ DTT as compared to without DTT (Figure 3.8). Thus, in presence of DTT, ABCP appears to be present as a monomer and loses its ability to transport substrates. These results taken together confirm that $\mathrm{ABCP}$ requires dimerization to be functional.

\section{Ethoxyresorufin $O$-deethylation (EROD) in placental microsomes (CYP1A1}

activity). As a positive control for the effects of smoking, we measured CYP1A1 function using the EROD assay. CYP1A1 activity was highly induced in smokers, however, we were only able to measure this activity in 2 out of 10 microsomal samples prepared from placentas of non-smokers. Table 3.2 shows the activity seen in each group and the range of values obtained. 


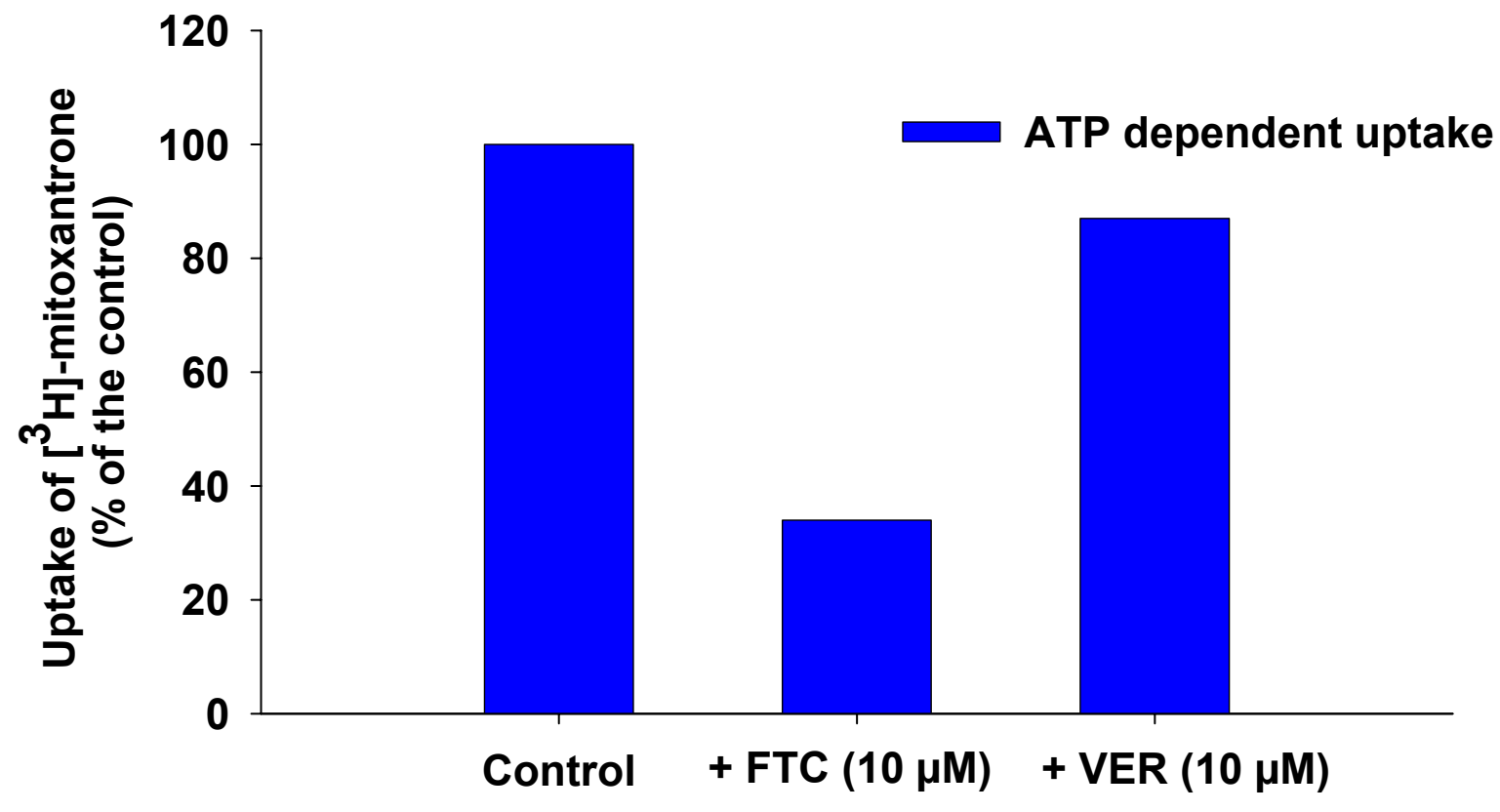

Figure 3-5 Effect of an ABCP inhibitor (FTC) and a P-gp inhibitor (VER) on the uptake of mitoxantrone in microvillus membrane vesicles

Data represent ATP dependent uptake of mitoxantrone. Fumitremorgin C (FTC) inhibited mitoxantrone uptake by $65 \%$ whereas verapamil (VER) had minimal effect on mitoxantrone transport suggesting that mitoxantrone transport is predominantly mediated by ABCP. Mean of triplicate determinations with coefficient of variation less than $15 \%$ for all sets. 


\section{Table 3-2 Functional activity of P-gp, ABCP and CYP1A1}

Functional activity (mean \pm SD) of P-gp and ABCP measured as uptake of vinblastine and mitoxantrone, respectively, in microvillus membrane vesicles. CYP1A1 activity $($ mean $\pm \mathrm{SD})$ measured as ethoxyresorufin $-O$-deethylation in placental microsomes.

\begin{tabular}{|l|c|c|}
\hline \multicolumn{1}{|c|}{ Parameter (units) } & $\begin{array}{c}\text { Smokers } \\
(\mathrm{n}=10)\end{array}$ & $\begin{array}{c}\text { Non-smokers } \\
(\mathrm{n}=10)\end{array}$ \\
\hline $\begin{array}{l}\text { P-gp mediated vesicular uptake of vinblastine } \\
\text { (pmol / mg of protein) }\end{array}$ & $2.25 \pm 1.12$ & $1.72 \pm 0.67$ \\
\hline $\begin{array}{l}\text { ABCP mediated vesicular uptake of mitoxantrone } \\
\text { (pmol / mg of protein) }\end{array}$ & $6.25 \pm 1.55$ & $5.53 \pm 2.09$ \\
\hline $\begin{array}{l}\text { CYP1 A1 activity in placental microsomes } \\
\text { (pmol / min / mg of protein) }\end{array}$ & $3.61 \pm 2.96$ & $(0.19,0.93) *$ \\
\hline
\end{tabular}

* Measurable values, 8 of the 10 samples were below the limit of detection. 


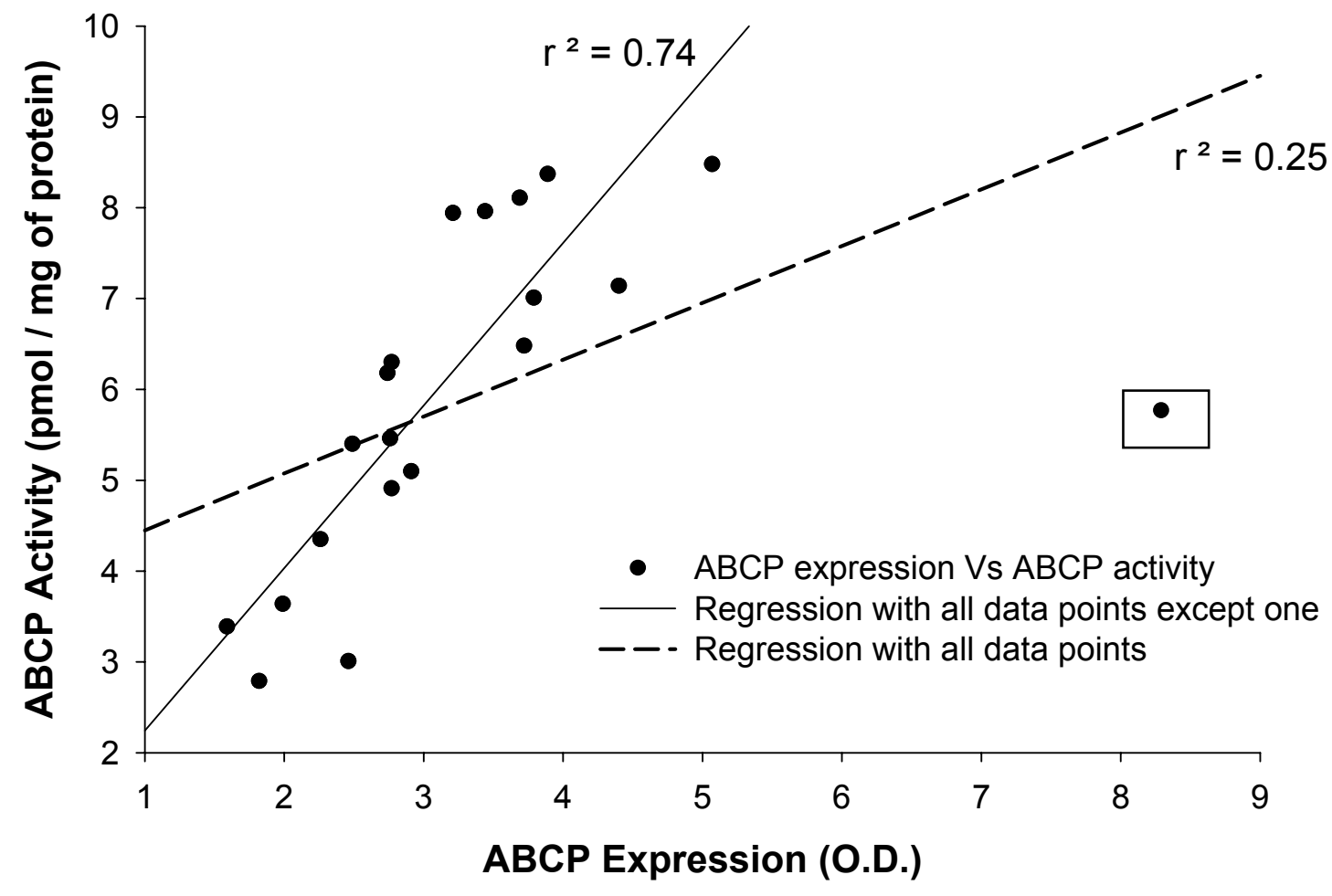

Figure 3-6 Correlation of $\mathrm{ABCP}$ activity with $\mathrm{ABCP}$ expression

The dashed line represents the regression line with all the data points and has a $\mathrm{r}^{2}=0.25$ whereas the solid line represents the regression line with all the data points except one which is shown in a box and has a $\mathrm{r}^{2}=0.74$. 


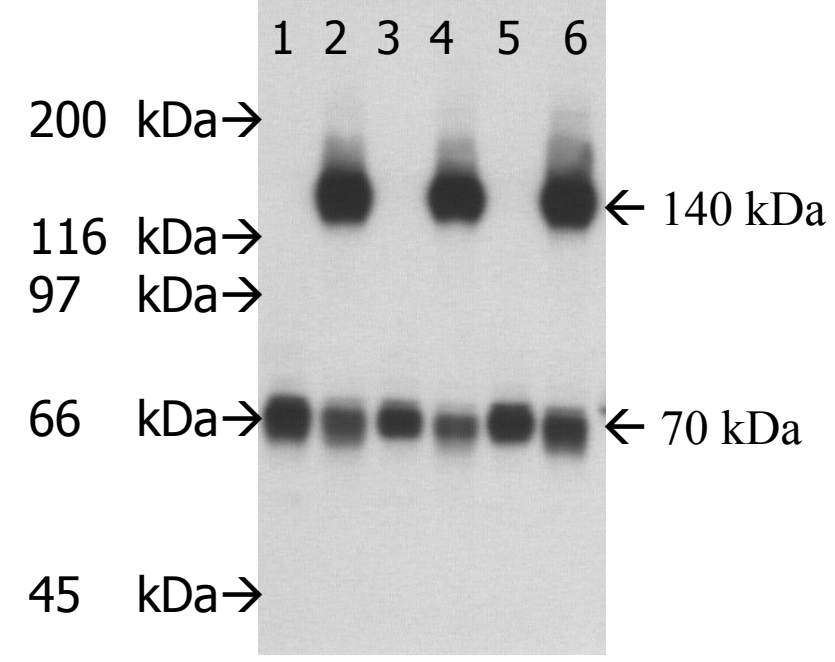

Figure 3-7 Immunoblot expression of $\mathrm{ABCP}$ in the presence and absence of reducing conditions

Electrophoresis was carried out under reducing conditions [presence of $1 \mathrm{mM}$ DTT] (lane 1, 3 and 5) and under non-reducing conditions [absence of $1 \mathrm{mM} \mathrm{DTT]} \mathrm{(lane} \mathrm{2,} 4$ and 6). Band at $140 \mathrm{kDa}$ is suggestive of the presence of a dimeric form of ABCP whereas the band at $70 \mathrm{kDa}$ is suggestive of a monomeric form. 


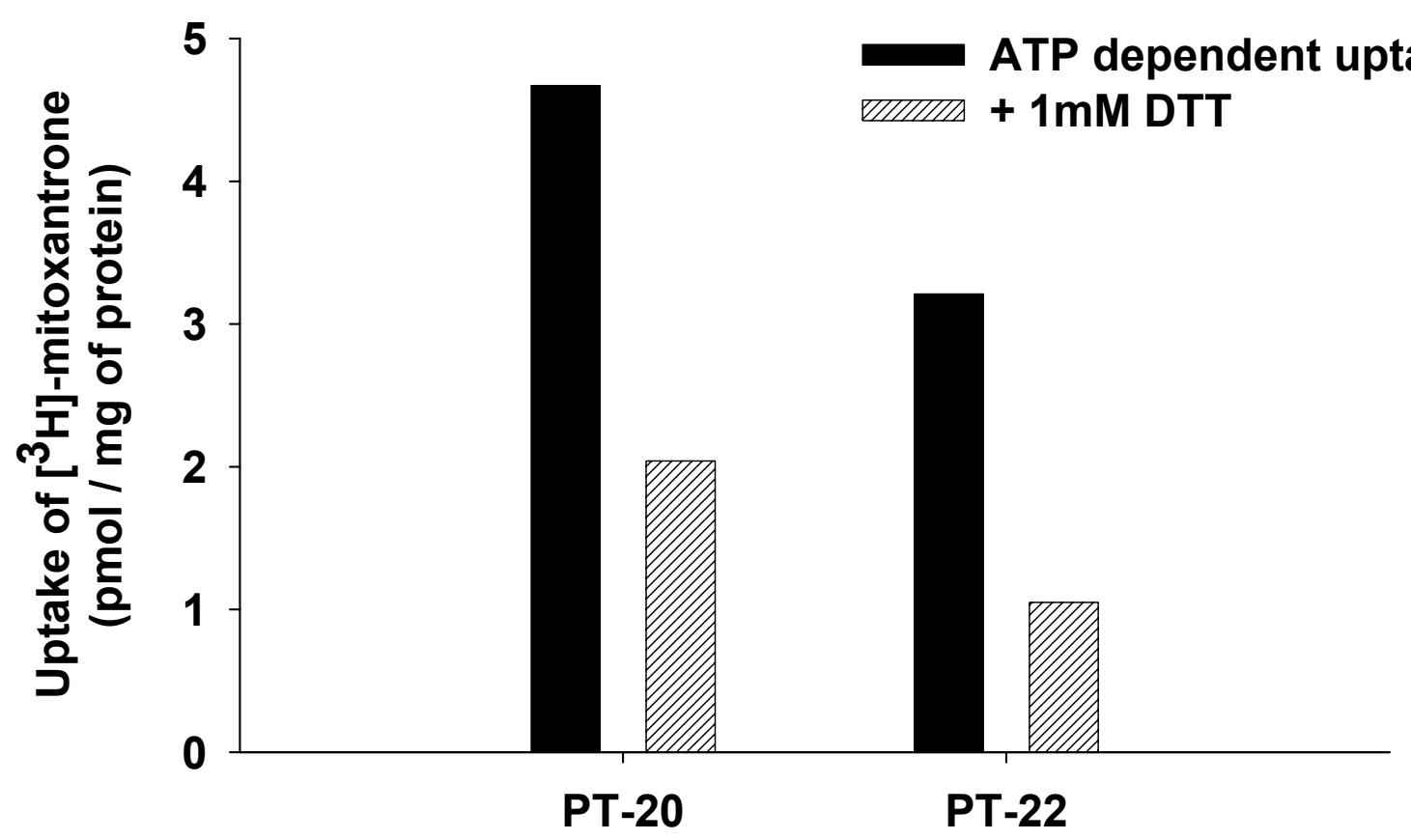

Figure 3-8 Effect of $1 \mathrm{mM}$ dithiothreitol (DTT) on ATP dependent uptake of mitoxantrone by ABCP in placental vesicles from two subjects (PT-20 and PT-22)

Uptake of $\left[{ }^{3} \mathrm{H}\right]$-mitoxantrone in placental vesicles $(25 \mu \mathrm{g})$ in the absence (dark bars) and presence (light bars) of $1 \mathrm{mM}$ DTT. Each bar represents the difference in uptake in presence and absence of ATP $(4 \mathrm{mM})$ carried out in triplicate and coefficient of variation was less than $15 \%$ for all sets. 


\subsection{Discussion}

PAHs, which are the principal constituents of cigarette smoke, have been shown to induce drug-metabolizing enzymes such as CYP1A1 in human placenta. It has been reported that PAHs such as 3-MC can induce the levels of P-gp mRNA in rat [76], mouse [77] and human hepatocytes [17]. However, the effect of smoking on placental drug efflux transporters, such as P-gp and ABCP, is not known. To this end, we studied the function and expression of placental P-gp and ABCP and their regulation by smoking in placentas from smokers and non-smokers.

Vinblastine was used as a model substrate of P-gp function in placental vesicles. To confirm that measured radioactivity on the filters was due to intravesicular transport and not just increased binding to vesicles, experiments in which increasing concentrations of sucrose were added to the transport buffer were conducted (Figure 3.2). Increased osmolarity of the medium should decrease the intravesicular volume and lead to decreased uptake in vesicles if intravesicular transport is occurring [84]. As seen in Figure 3.2, the uptake of vinblastine decreased as the osmolarity of the transport buffer increased, demonstrating that the observed ATP dependent transport was at least partly intravesicular and not due to increased binding of vinblastine to P-gp. Additional confirmation of the involvement of P-gp in this active transport process was obtained by using verapamil, an established inhibitor of P-gp. Verapamil $10 \mu \mathrm{M}$ and $100 \mu \mathrm{M}$ inhibited ATP dependent vinblastine uptake by $42 \%$ and $71 \%$, respectively (Figure 3.3). That the process was osmotically sensitive and inhibited by a known P-gp inhibitor strongly suggests that the ATP dependent transport of vinblastine was intravesicular and carried out by P-gp. 
In addition to P-gp, ABCP also has been reported to be present at the apical surface of placenta. To the best of our knowledge, there are no reports of functional studies of $\mathrm{ABCP}$ in human placenta. Mitoxantrone, a known substrate for $\mathrm{ABCP}$, was used to measure $\mathrm{ABCP}$ function in the microvillus membrane vesicles. To verify the involvement of $\mathrm{ABCP}$ in mitoxantrone transport, uptake experiments were performed in the presence of fumitremorgin $\mathrm{C}(10 \mu \mathrm{M})$, a selective inhibitor of $\mathrm{ABCP}$ [44], and verapamil $(10 \mu \mathrm{M})$, a P-gp inhibitor. As shown in Figure 3.4, fumitremorgin C inhibited mitoxantrone uptake by $65 \%$ whereas verapamil exhibited minimal effect. Since verapamil exhibited a minimal effect on mitoxantrone uptake, suggests that the uptake of mitoxantrone was primarily mediated by $\mathrm{ABCP}$ and not by $\mathrm{P}-\mathrm{gp}$.

$\mathrm{ABCP}$ is a half transporter and has 6 transmembrane domains and only one ATP binding site, unlike P-gp which is a full transporter and has twelve transmembrane domains and two ATP binding sites [14]. As ABCP is a half transporter, it is assumed to require dimerization to be a functional protein [89]. In its monomeric form, $\mathrm{ABCP}$ migrates as a $70 \mathrm{kDa}$ protein. However, under non-reducing conditions $\mathrm{ABCP}$ migrates as a $140 \mathrm{kDa}$ protein, suggesting it forms a dimer [39]. To confirm this dimerization, placental vesicle samples were electrophoresed under reducing (in the presence of DTT) and non-reducing conditions (in the absence of DTT) (Figure 3.5). Under the nonreducing conditions a large band was observed at $140 \mathrm{kDa}$, whereas this band was completely absent when samples were electrophoresed under reducing conditions, wherein it migrated as a $70 \mathrm{kDa}$ protein. The minimal expression of $70 \mathrm{kDa}$ protein seen under non-reducing conditions could be due to some $\mathrm{ABCP}$ monomers that had not dimerized. To confirm that dimerization of $\mathrm{ABCP}$ is necessary for functionality, we 
performed mitoxantrone uptake studies in the presence and absence of $1 \mathrm{mM}$ DTT (Figure 3.6). As DTT is a reducing agent, it should cleave the dimer and thus decrease the functional activity of $\mathrm{ABCP}$. An approximately $65 \%$ reduction in mitoxantrone uptake was noted in the presence of DTT as compared to the absence of DTT. These results suggest that $\mathrm{ABCP}$ dimerization is required for functionality. Since no dimer was detected in the immunoblotting studies in the presence of DTT (reducing conditions), the small amount of mitoxantrone transport noted in the presence of $1 \mathrm{mM}$ DTT was most likely due to the binding of mitoxantrone to ABCP in presence of ATP.

Though substantial expression of P-gp and ABCP protein in placental vesicles was noted, no statistical differences were noted in expression levels between smokers and non-smokers (Table 3.1). Likewise, no statistical difference was noted in P-gp and ABCP functional activity between these two groups (Table 3.2), however, statistical power was low. To achieve a power of 0.8 at $p<0.05$, it was calculated that a sample size of 26 subjects per group would be required to meet these statistical levels for ABCP expression and substantially higher numbers of samples for P-gp expression and activity and for ABCP activity.

As mentioned above, substantial inter-individual variability was seen in the expression and activity of P-gp and ABCP in human placental samples (Table 3.1 and 3.2). Induction of the $A B C B 1$ gene by 3-MC and TCDD in human hepatocytes has been reported by Schuetz et al. [17]. Primary human hepatocytes from 15 individuals were treated with 3-MC and TCDD, from which only $62 \%$ and $55 \%$, respectively, of the primary hepatocyte cultures showed induction of the $A B C B 1$ gene, suggesting that this inducibility was polymorphic [17]. Genotyping studies have reported a SNP at C3435T 
in exon 26 and subjects having the T/T allele exhibited much lower expression and activity of P-gp measured in-vivo, suggesting a correlation between the genotype and phenotype [33;34]. However, other researchers have reported that individuals with the $\mathrm{T} / \mathrm{T}$ allele exhibit higher expression of P-gp and thus higher activity [35]. Thus, the effects of genetic polymorphisms with respect to the direction of change in P-gp expression and activity are still unclear. These types of polymorphisms may in part, explain the substantial inter-individual variability in P-gp expression and activity noted in the present study. Mutations in the amino acid at position 482 in ABCP overexpressing cells lines have also been reported, resulting in an alteration in substrate specificity of $\mathrm{ABCP}$. The wild type $\mathrm{ABCP}$ has arginine at position 482, which is replaced by threonine or glycine in mutated cells $[43 ; 53]$. Whether these mutations exist in normal human tissues and change the expression and function of $\mathrm{ABCP}$ is not yet known. To this end, we have begun studies to genotype the samples used in our study for correlation of genotype, phenotype and smoking status for both P-gp and ABCP.

To assure that maternal smoking was resulting in alterations in placental biochemical processes, measurement of CYP1A1 activity in placental microsomes was used as a positive control. CYP1A1 activity was substantially greater in smokers as compared to non-smokers (Table 3.2). Since smoking induced CYP1A1 activity but not P-gp or ABCP activity, the lack of effect appears not to be due to insufficient smoking activity necessary to induce biochemical processes such as P-gp or ABCP activity.

In conclusion, we were able to measure $\mathrm{P}$-gp and $\mathrm{ABCP}$ expression and activity in placental membrane vesicles. This constitutes the first report of functional studies on 
$\mathrm{ABCP}$ in human placenta. However, it appears that smoking does not induce P-gp or $\mathrm{ABCP}$ activity or expression in human placenta. 


\section{Acknowledgements}

We would like to thank Dr. Joseph A. Ware for his useful suggestions in designing the experiments. 


\section{CHAPTER - IV}

\section{INDUCTION OF P-GLYCOPROTEIN AND CYP3A ACTIVITIES IN LS174T CELLS}


P-gp can affect drug bioavailability as it plays a role in absorption, distribution and elimination. Induction of P-gp leads to decreased absorption and increased elimination of drug substances and can play a role in drug-drug interactions. Such interactions become extremely important for drugs that are P-gp substrates and have narrow therapeutic indices. Our laboratory was interested in studying the induction of Pgp by various xenobiotics. At the same time, I was offered an opportunity to do a summer internship at Pharmacia Corp., Kalamazoo, MI, under the direction of Dr. Joseph Ware. As a part of my summer internship, I worked on a project to evaluate LS174T cells as a model cell line to study the induction of P-gp and CYP3A4 simultaneously.

P-gp and CYP3A4 have a number of overlapping substrates and are co-localized in various tissues such as intestine, liver and kidney. Common substrates are pumped back into the gut lumen by P-gp and metabolized by intestinal CYP3A4; thus, P-gp and CYP3A4 act additively to decrease the oral bioavailability of several xenobiotics. In addition, both proteins are known to be coordinately upregulated. To this end, development of a common system for studying both P-gp and CYP3A4 induction simultaneously could prove beneficial to the drug discovery process.

LS174T, a colon carcinoma cell line, has been used as an intestinal model. It has been shown that in these cells the $A B C B 1$ gene is inducible by rifampin. There are reports of increased expression of P-gp in these cells, however, whether CYP3A4 is also induced in these cells has not been studied. Given that both of these proteins have common inducers and are induced in intestinal tissue, the LS174T cell line seemed ideal for studying the simultaneous induction of P-gp and CYP3A4. 
The pregnane X-receptor (PXR) is a nuclear hormone receptor and is a key regulator of CYP3A4 induction. Recently, its involvement in the regulation of the $A B C B 1$ gene has also been noted. PXR binding element is present in the upstream region of $A B C B 1$ gene in LS174T cells. At Pharmacia, Dr. Rich Voorman and Evan Smith use a reporter gene assay to screen compounds for their ability to activate PXR. Since PXR is identified as a key regulator in the induction of P-gp and CYP3A4, the reporter gene assay results can be used for prediction of induction of P-gp and CYP3A4. Our second purpose was to determine how data from the PXR reporter gene assay would correlate with results from induction studies in LS174T cells. Thus a collaboration with Dr. Rich Voorman and Evan Smith was formed to evaluate the correlation of these results. Compounds which were poor, intermediate and strong activators of PXR were selected and their ability to induce P-gp in LS174T cells was compared and correlated to their ability to activate PXR in a reporter gene assay.

The following chapter describes the experimental procedures used in these studies, their results and a discussion of the findings. I would like to thank Dr. Rich Voorman and Evan Smith for sharing the PXR reporter gene assay data that is presented in the next chapter with me. 


\subsection{Introduction}

Prediction of drug-drug interactions early in the development of new drugs is beneficial in the process of drug discovery. Induction of drug metabolizing enzymes and transporters that govern the absorption, distribution, metabolism and excretion of drugs is one cause of drug-drug interactions [22;90].

The $A B C B 1$ (MDR1) gene encodes for P-glycoprotein (P-gp), an ATP dependent integral transmembrane protein which acts as an efflux transporter. It pumps xenobiotics out of cells and decreases their intracellular concentrations [4]. It is expressed in various tissues including intestine, liver, kidney, brain and placenta [87] wherein it plays a role in absorption, distribution and excretion of xenobiotics.

Cytochrome P450 3A4 (CYP3A4) is an important drug metabolizing enzyme constituting about $70 \%$ of intestinal and $30 \%$ of the hepatic P450 metabolizing enzymes

present. It is responsible for metabolism of more than half of the drugs on the market [91;92]. Induction by a variety of chemicals augments the metabolism and clearance of co-administered drugs which are CYP3A4 substrates and can lead to alteration of their therapeutic efficacy [93;94]. Because of this, it is desirable to screen compounds for their ability to induce CYP3A.

P-gp has broad substrate specificity with many compounds also being CYP3A4 substrates [16]. Both proteins are expressed in several common tissues [95] and can additively affect the bioavailability of certain drugs [96;97]. Moreover, it has also been shown that both proteins are coordinately upregulated in colon carcinoma cells when exposed to common inducing agents [16]. Therefore, in addition to screening for 
inducibility of CYP3A, compounds should also be screened for their ability to induce Pgp. In addition, the functional activity of these induced proteins is critical.

Induction of CYP3A by different agents has been studied in animals [18], hepatocytes [98;99] and cell lines [16]. However, only recently has the molecular mechanism of induction been known. Pregnane xenobiotic receptor (PXR), a nuclear hormone receptor, has been found to be responsible for drug induced expression of CYP3A4 [100;101]. PXR has also been implicated in the induction of P-gp [24]. A PXR response element to which PXR can bind was found in the 5' upstream region of the $A B C B 1$ gene [27]. As CYP3A4 and P-gp both depend on PXR for the control of expression, it is important to assess whether induction by various agents is common to each protein as well. The colon carcinoma cell line LS174T has been shown to possess the $A B C B 1$ gene which can be induced [27]. In the present work, this cell line was used to develop a model for simultaneous assessment of drug candidates for their ability to induce P-gp and CYP3A4 activity. To further support the involvement of PXR in induction of $A B C B 1$, the ability of various drugs to activate PXR was compared and correlated with their ability to induce P-gp. 


\subsection{Methods}

Materials. $\left[{ }^{3} \mathrm{H}\right]$-vinblastine was purchased from Amersham Biosciences, (Piscataway, NJ). Cyclosporin A was purchased from Fluka (Switzerland). The chemicals with PNU number were synthesized by Pharmacia Corp. (Kalamazoo, MI). All other chemicals were purchased from commercial sources and were of the highest purity available.

Cell Culture. The colon carcinoma cell line LS174T was obtained from the American Type Culture Collection. The cells were maintained in Minimum Essential Media supplemented with $10 \%$ fetal bovine serum, $0.1 \mathrm{mM}$ nonessential amino acids, sodium pyruvate and glutamine (Invitrogen). The medium was changed every 3 days and the cells were subcultured at the ratio of $1: 3$ to $1: 5$. In a 6 well culture plate at $50 \%$ confluence, cells were treated with drugs dissolved in DMSO ( $0.1 \%$ final concentration). $0.1 \%$ DMSO was used as solvent control in cells not treated with drugs. Treatment with drugs was continued for 72 hours or the indicated time, after which the cells were washed twice with phosphate buffered saline and then lysed with lysis buffer (50mM Tris, $\mathrm{pH}$ 7.0, 1.0\% Triton X-100, 1 Protease Minitab (Boehringer Ingelheim) $/ 10 \mathrm{~mL}$ ). The cell lysate was stored at $-80^{\circ} \mathrm{C}$. Protein content was determined using the $\mathrm{BCA}$ protein assay kit (Pierce).

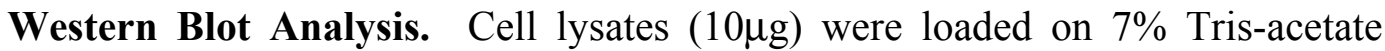
mini-gels (Invitrogen) and electrophoresed. The proteins were transferred to a 
nitrocellulose membrane and stained with Ponceu S solution (Sigma) to confirm transfer. The membrane was blocked in blocking buffer (5\% non-fat dry milk in Tris buffered saline) for $1 \mathrm{~h}$ at room temperature and then incubated with C-219 P-gp antibody (1:1000, Signet laboratories) overnight at $4^{\circ} \mathrm{C}$. The membrane was then washed with Tris buffered saline containing $0.1 \%$ Tween 20 (TTBS) and incubated with horseradish peroxidase linked sheep antimouse antibody (1:5000, KPL laborartories) for $1 \mathrm{~h}$ at room temperature. After washing with TTBS, the blots were developed with enhanced chemiluminescence detection system (Amersham Pharmacia Biotech). The relative amounts of P-gp were determined by densitometric analysis after scanning the blot using a Bio-Rad densitometer.

Flow Cytometry. Cell suspensions $(100 \mu \mathrm{l})$ at $1-2 \times 10^{6}$ cells $/ \mathrm{ml}$ were incubated with either control ( $\gamma_{2 \mathrm{a}}$, Becton Dickinson) or anti-P-gp (MRK-16, Kayima Biomedical Co.) monoclonal antibodies $(20 \mu \mathrm{l}$ at $50 \mu \mathrm{g} / \mathrm{ml})$ for $1 \mathrm{~h}$ at room temperature. After centrifugation and removal of supernate, fluorescent-goat anti-mouse $\operatorname{IgG}(100 \mu 1$ at 1/50 dilution) was added and incubated for $45 \mathrm{~min}$ at room temperature, followed by centrifugation and resuspension in $200 \mu \mathrm{l}$ sheath buffer (Becton Dickinson). Samples were analyzed in a FACScan (Becton Dickinson) flow cytometer by gating on cells using forward (FSC) and side (SSC) scatter parameters and measuring fluorescence at $530 \mathrm{~nm}$ (FL1 channel).

Uptake of $\left[^{3} \mathbf{H}\right]$-Vinblastine. Cells were grown at high density in 24 well plates with 12 wells treated with $10 \mu \mathrm{M}$ rifampin and the other 12 wells with $0.1 \%$ DMSO 
solvent control. At the end of $72 \mathrm{~h}$ the cells were washed twice with PBS at $37^{\circ} \mathrm{C}$ with mixing. The control wells and rifampin treated wells were pretreated with $5 \mu \mathrm{M}$ cyclosporin $A(n=6)$ and vehicle $(n=6)$ for 30 min at $37^{\circ} \mathrm{C} . \quad\left[{ }^{3} \mathrm{H}\right]$-vinblastine $(0.25$ $\mu \mathrm{Ci} / \mathrm{mL}$ ) was added and incubated for $1 \mathrm{~h}$ at $37^{\circ} \mathrm{C}$ with mixing. At the end of $1 \mathrm{~h}$ the remaining solution was aspirated and the cells were rinsed twice with ice-cold PBS. The cells were then dissolved in Solvable $\mathrm{TM}$ for $30 \mathrm{~min}$ at $37^{\circ} \mathrm{C}$ and transferred to a scintillation vial to measure the amount of cell associated radioactivity.

Measurement of 1'-hydroxy midazolam. The LS174T cells were washed twice with PBS and then incubated with $10 \mu \mathrm{M}$ midazolam at $37^{\circ} \mathrm{C}$ for $1 \mathrm{~h}$ on a slow shaker. At the end of $1 \mathrm{~h}$ the reaction was stopped with quenching solution $(5 \mu \mathrm{g} / \mathrm{ml}$ of carbamazepine (internal standard) in methanol and 3\% formic acid). The contents of each well were transferred to tubes and centrifuged $(14000 \mathrm{rpm})$. The supernate was analyzed for 1'-hydroxy midazolam using LC-MS analysis. LC/MS was performed in positive ion scan mode on a Finnigan-MAT TSQ 7000, and by gradient reverse-phase chromatography $(0.1 \%$ formic acid $95 \%$ to $0 \%$ in $\mathrm{ACN}$ over $20 \mathrm{~min})$ on a Zorbax $\mathrm{C} 18$, $150 \times 2.1 \mathrm{mM}$ i.d. reverse-phase column $(0.3 \mathrm{ml} / \mathrm{min})$. Extracted ion chromatograms of carbamazepine $\left(\mathrm{MH}^{+} \mathrm{m} / \mathrm{z}\right.$ 237) and hydroxy-midazolam $\left(\mathrm{MH}^{+} \mathrm{m} / z\right.$ 342) were obtained and used to determine peak area ratios (metabolite-of-interest / carbamazepine).

PXR reporter gene assay: HUH7 cells, maintained in RPMI Medium 1640 (Invitrogen Corporation, Carlsbad, CA) supplemented with 10\% heat-inactivated FBS (Invitrogen), 100 units $/ \mathrm{mL}$ penicillin $\mathrm{G}$ (Invitrogen) and $100 \mu \mathrm{g} / \mathrm{mL}$ streptomycin sulfate 
(Invitrogen), were plated at a density of $50,000 \mathrm{cells} / \mathrm{cm}^{2}$ growth surface area in $150 \mathrm{~mm}$ x $25 \mathrm{~mm}$ tissue culture dishes. After eight hours, cells were transfected with $5.8 \mu \mathrm{g} / \mathrm{dish}$ of receptor expression plasmid and $23.4 \mu \mathrm{g} /$ dish of reporter plasmid using Lipofectamine 2000 (Invitrogen) essentially according to the manufacturer's instructions. Eighteen hours after transfection, cells were detached and diluted to 50,000 cells $/ \mathrm{mL}$ with reduced serum medium (RPMI Medium 1640 supplemented with 1\% FBS). The diluted cell suspension was added to 96 -well assay plates (200 $\mu \mathrm{L} /$ well) containing $1 \mu \mathrm{L}$ samples of test compounds dissolved in DMSO. Cells were incubated in the presence of test compounds for 24 hours before detection of luciferase activity using Sleady-Glo luciferase detection reagent (Promega). Fold induction values were calculated by dividing the luminescence response for the test well of a given compound with the average luminescence response of the four DMSO control wells on the same plate.

Statistical Analysis. Unistat $^{\circledR}$ version 5.0 was used for comparison of the two groups. Correlations between groups were measured by Pearson's correlation comparisons and statistical significance was set at $p<0.05$. 


\subsection{Results}

P-gp expression and function in LS174T cells. Rifampin, a prototypical inducer of P-gp expression was used to characterize the induction of P-gp expression in LS174T cells. Immmunoblotting results demonstrated that induction by rifampin was dose (Figure 4.1) and time dependent (data not shown). Based on these results, a dose of $10 \mu \mathrm{M}$ and $72 \mathrm{~h}$ time exposure were used in all further experiments. In addition to rifampin, reserpine also induced P-gp expression (data not shown). To determine the surface expression of P-gp in LS174T cells, flow cytometry measurements were carried out using MRK-16 anti P-gp antibody that recognizes the external epitope of P-gp. Vehicle (DMSO) and rifampin / reserpine treated cells were analyzed for their binding to control and MRK -16 antibody. The fluroscence intensity was 3.5 and 4.0 fold higher in rifampin and reserpine treated cells respectively as compared to vehicle control treated cells (Figure 4.2). This suggests that the induced protein is present at the cell surface of the cells. To determine if the induced protein was functionally active, cellular uptake of $\left[{ }^{3} \mathrm{H}\right]$-vinblastine was measured in the presence and absence of cyclosporin A (CsA, 5 $\mu \mathrm{M})$. As seen in Figure 4.3, $\left[{ }^{3} \mathrm{H}\right]$-vinblastine uptake was significantly lower $(p<0.05)$ in rifampin treated cells as compared to vehicle control cells. Uptake in the CsA treated control cells was significantly higher $(p<0.05)$ than in control cells without CsA suggesting that baseline P-gp activity was inhibited by CsA. Uptake of $\left[{ }^{3} \mathrm{H}\right]$-vinblastine in rifampin treated cells also was higher in the presence of CsA than in the absence of CsA, however, this increase was not statistically significant. 


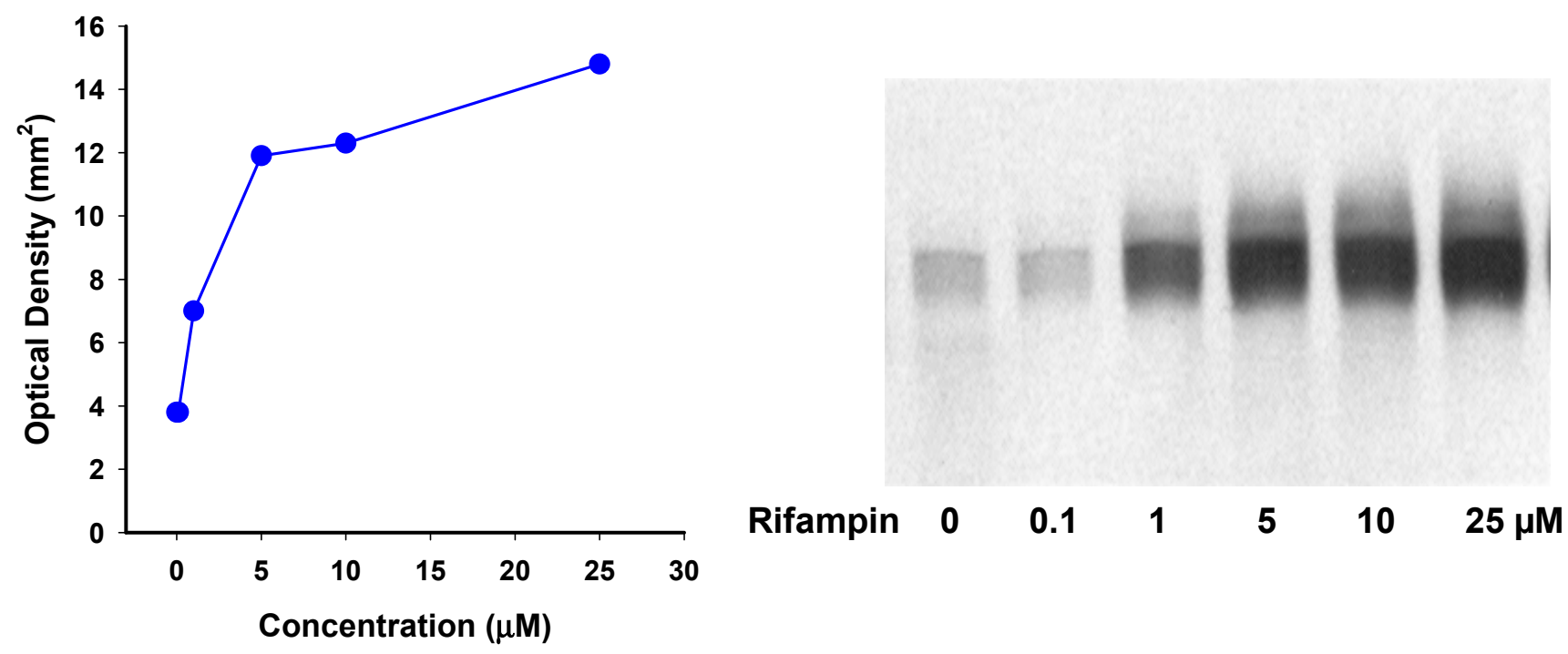

Figure 4-1 Dose dependent induction of immunoreactive P-glycoprotein after rifampin treatment

Cells at $50 \%$ confluency were treated with vehicle (DMSO) or $0.1,1,5,10$ and $25 \mu \mathrm{M}$ of rifampin for $72 \mathrm{hrs}$. At the end of $72 \mathrm{hrs}$ the cell lysate was analyzed for P-gp expression by immunoblot analysis. 


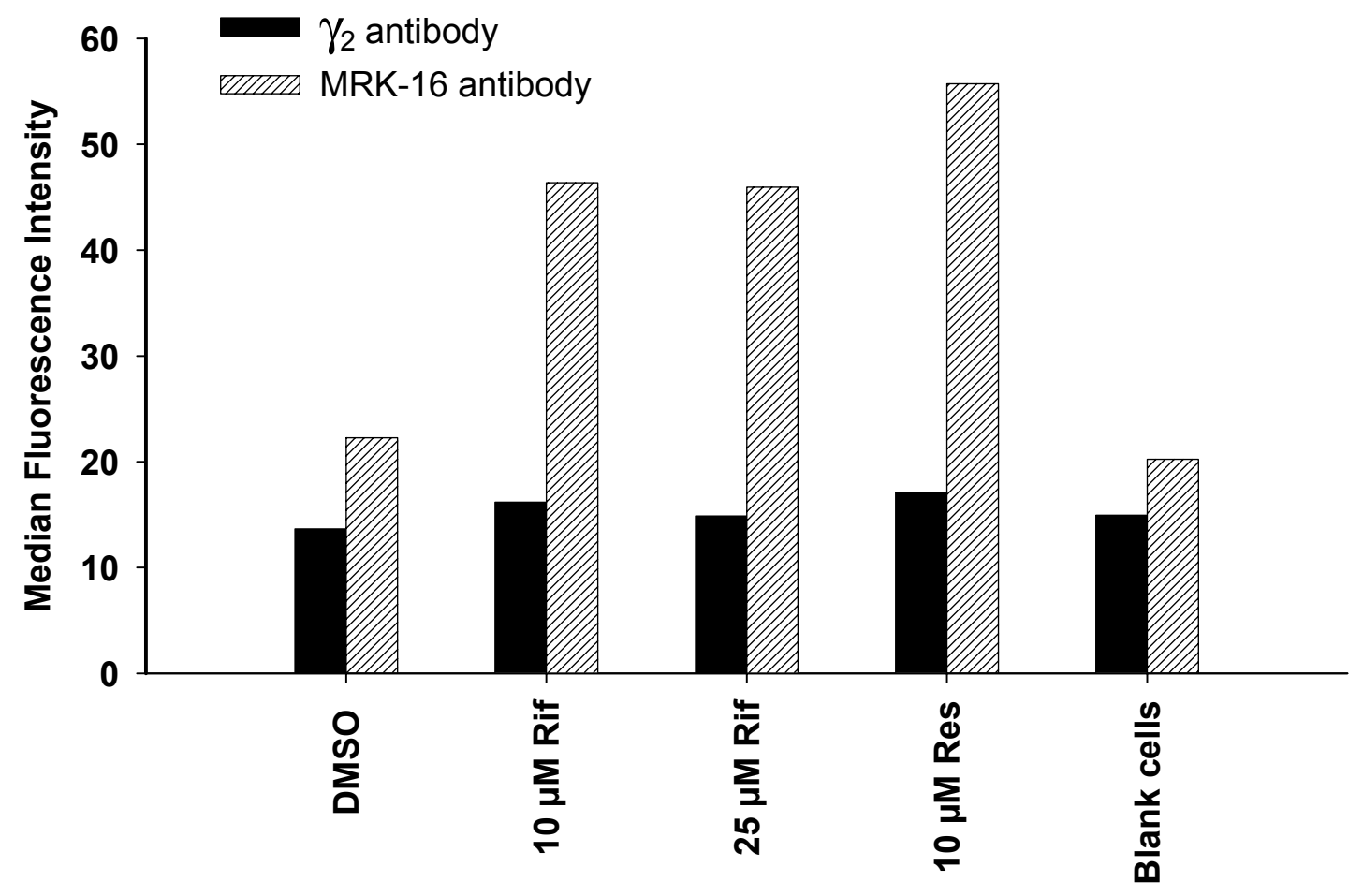

Figure 4-2 Determination of surface expression of P-gp in LS174T cells after treatment with rifampin and reserpine for 72 hours

Anti-P-gp antibody (MRK-16) and control antibody $\left(\gamma_{2}\right)$ were incubated with solvent control (DMSO), drug treated cells (rifampin, Rif; reserpine, Res) and blank cells (without solvent or drug treatment). After washing, the cells were incubated with fluorescent-labeled secondary antibody. Samples were analyzed for fluorescence intensity at $530 \mathrm{~nm}$ in a flow cytometer. 


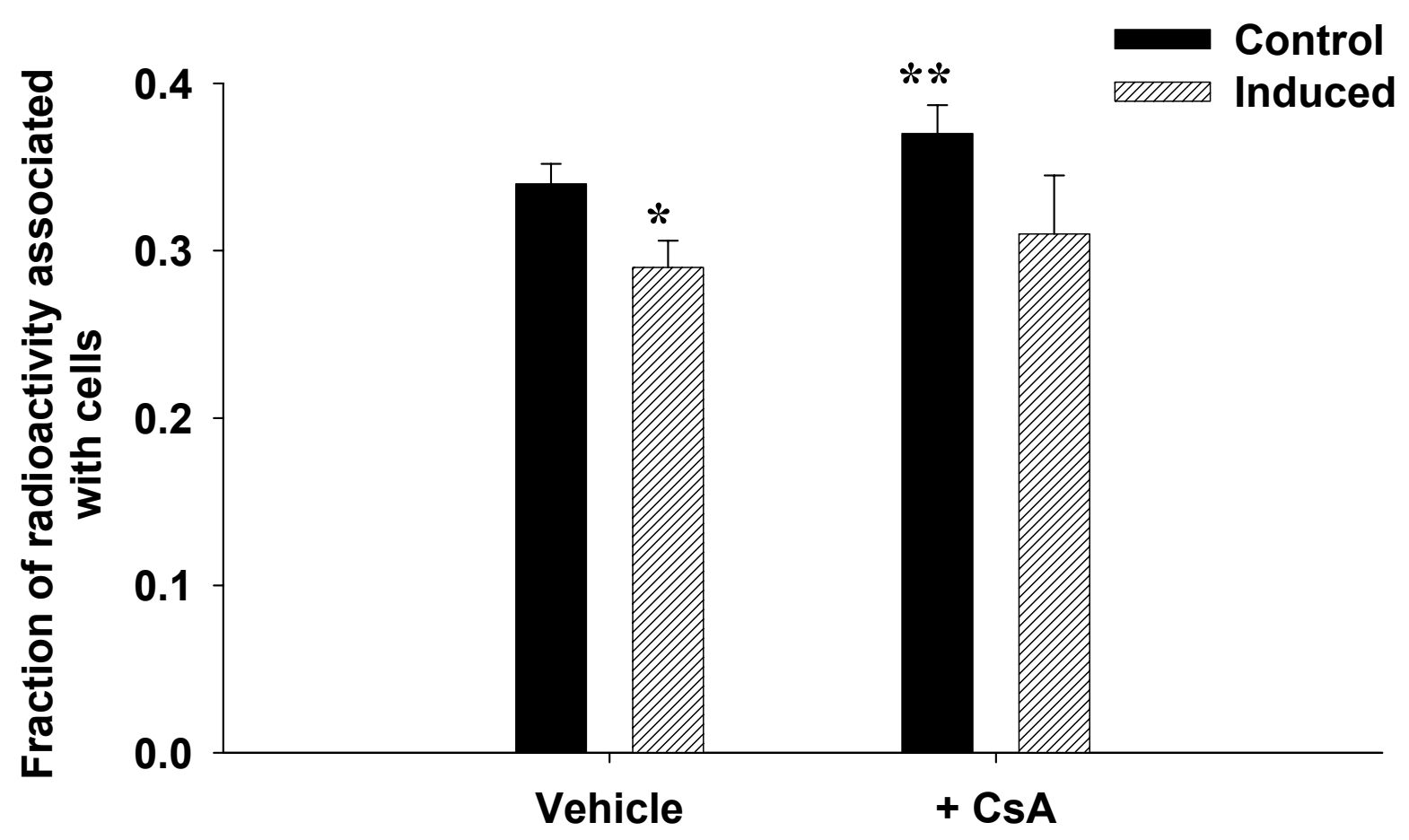

Figure 4-3 Uptake of vinblastine in control and rifampin treated cells in the presence and absence of $5 \mu \mathrm{M}$ cyclosporin A (CsA)

Bars represent the means \pm std.dev $(n=6)$. Cells were treated with either DMSO (dark bars) or $10 \mu \mathrm{M}$ rifampin (hatched bars) for $72 \mathrm{~h}$.

$* p<0.05$ as compared to vehicle control. Reduction in uptake due to the induction of Pgp by rifampin.

** $p<0.05$ as compared to vehicle control. Enhanced uptake due to the inhibition of P-gp by cyclosporin A (+ CsA) 
CYP3A4 activity in LS174T cells after rifampin treatment. Metabolism of midazolam to 1 '-hydroxy midazolam (1'-OH MDZ) was used to measure CYP3A activity. Formation of 1'-OH MDZ was found to be four times higher in rifampin treated cells as opposed to control cells (Figure 4.4). Additionally, 1'-OH MDZ formation was inhibited by $10 \mu \mathrm{M}$ ketoconazole, a CYP3A inhibitor, Figure 4.4. 


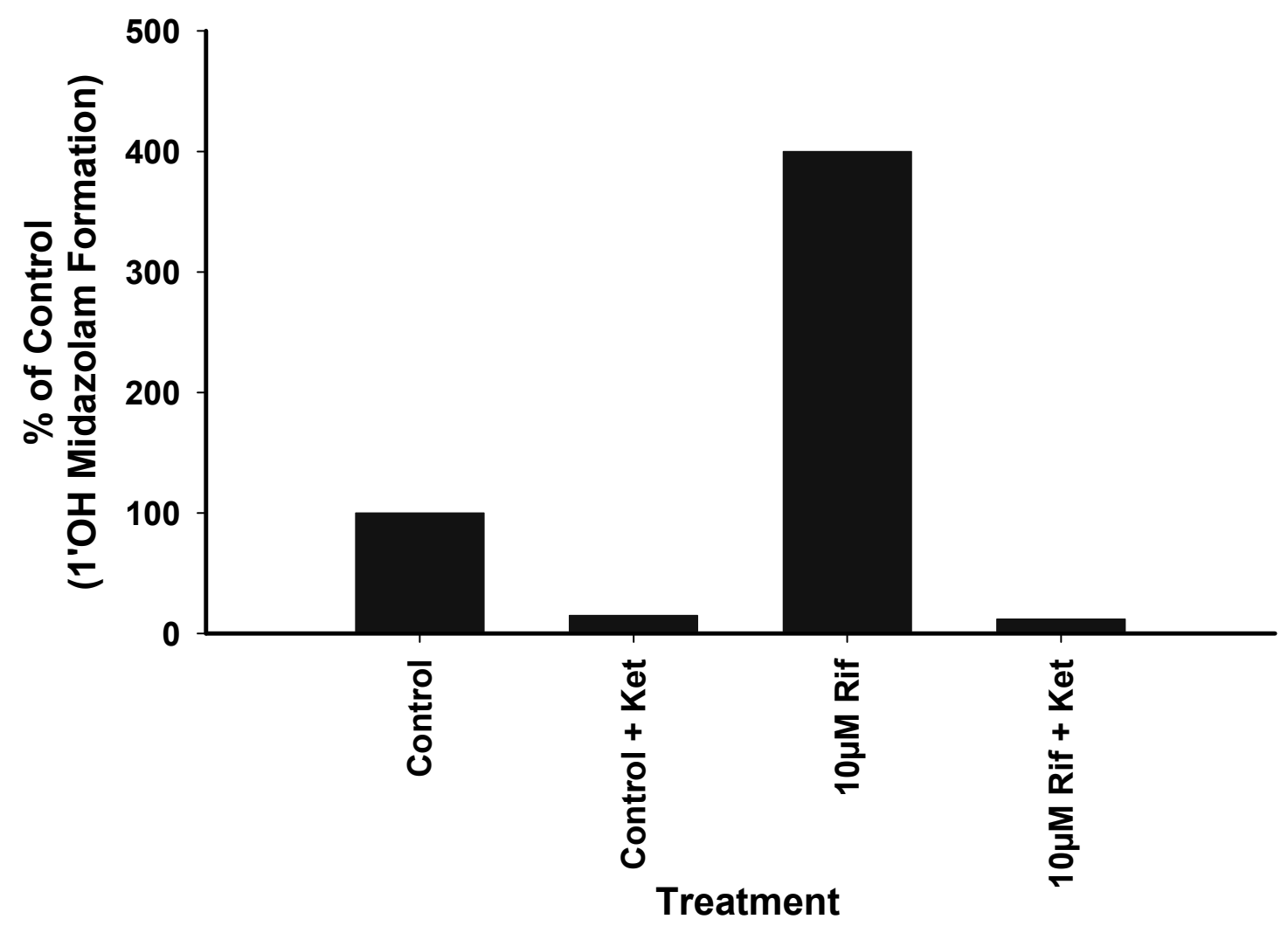

Figure 4-4 Induction of CYP3A activity after $10 \boldsymbol{\mu M}$ rifampin treatment.

Formation of 1'-hydroxy midazolam was measured in control and rifampin (Rif) treated cells after treatment for $72 \mathrm{hrs}$. The metabolite production was completely inhibited in presence of $10 \mu \mathrm{M}$ ketoconazole (Ket) in both the control and rif treated cells. 
Correlation of PXR activation and P-gp induction. A total of 18 compounds, with known affinity for PXR, were tested for their ability to induce P-gp. Compounds with high, intermediate and low affinity for PXR were selected and LS174T cells were treated with $10 \mu \mathrm{M}$ of drug (except for hyperforin which was tested at $1 \mu \mathrm{M}$ ) in DMSO for 72 h. P-gp expression was measured by immunoblotting and densitometric values were determined after scanning the blots. Fold change was calculated with respect to DMSO control. In Figure 4.5, the fold change in activation of PXR and expression of Pgp is plotted for each of the compounds tested. Of the 18 compounds tested, rifampin, PNU-721, PNU-444, PNU-690 and SR12813 were strong activators of PXR as well as greatly induced P-gp expression. Taxol, verapamil and PNU 352 strongly induced P-gp expression but moderately activated PXR. On the other hand hyperforin strongly activated PXR but had very little inducing effect on P-gp expression. Similarly, troglitazone was a moderate PXR activator but failed to increase P-gp expression. Lastly phenytoin and delavirdine resulted in a moderate increase in P-gp expression but failed to activate PXR. Ibuprofen and dexamethasone did not activate PXR or increase P-gp expression. The ability of the tested compounds to induce P-gp and activate PXR was rank ordered and although the rank order differed for P-gp induction and PXR activation, a positive correlation coefficient of 0.53 (Figure 4.6) was noted which was statistically significant $(p<0.05)$. 


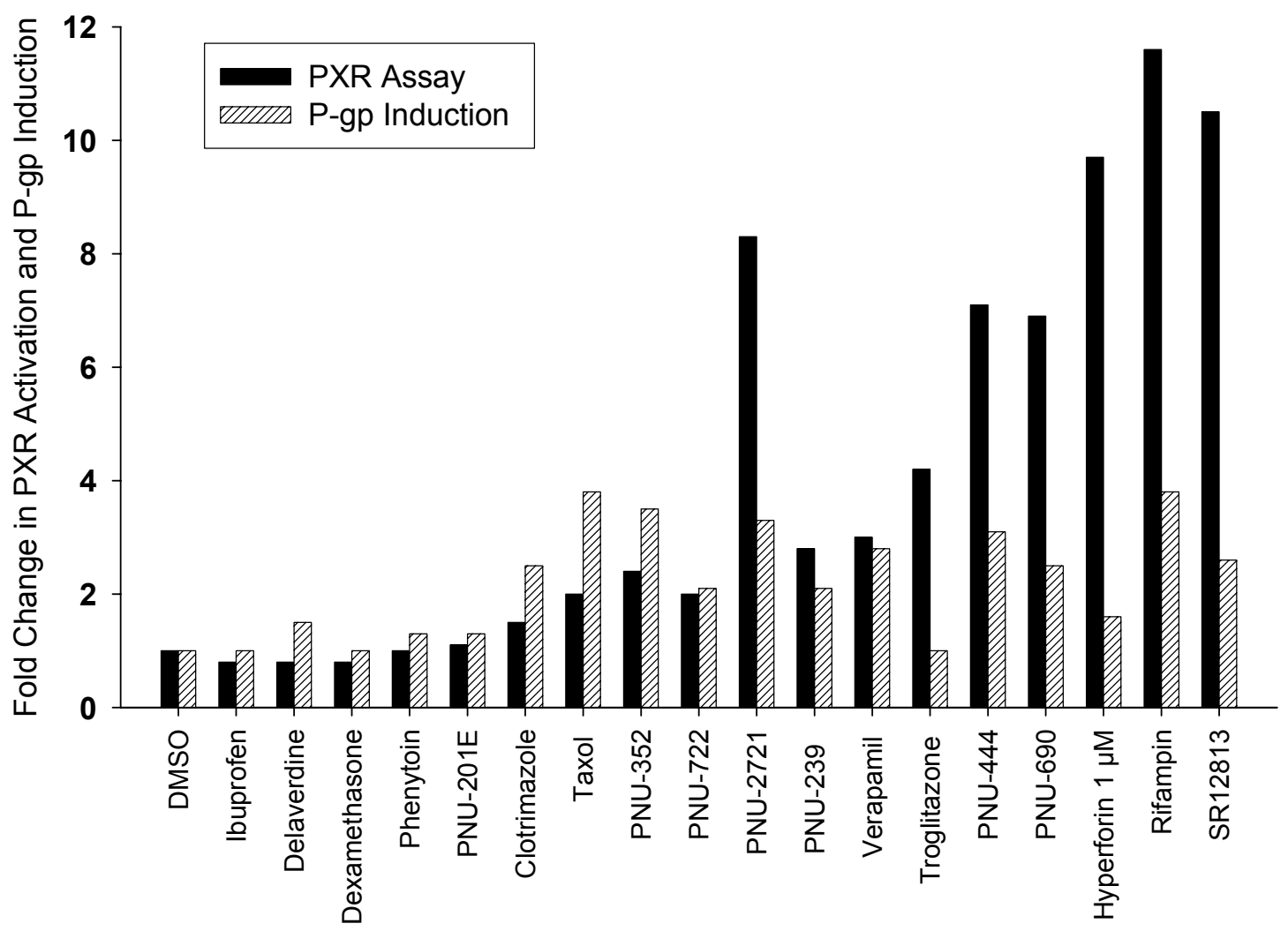

Figure 4-5 Comparison of PXR Activation and P-gp Induction by Various Agents

LS174T cells were treated with $10 \mu \mathrm{M}$ of each compound ( $1 \mu \mathrm{M}$ hyperforin) for $72 \mathrm{hrs}$. At the end of $72 \mathrm{hrs}$, cells were lysed and P-gp protein abundance was measured by immunoblotting analysis. Blots were scanned and densitometric values were calculated. P-gp induction is reported as the fold change over the vehicle control. Likewise, for the PXR reporter gene assay, data are reported as the fold change over vehicle control. 


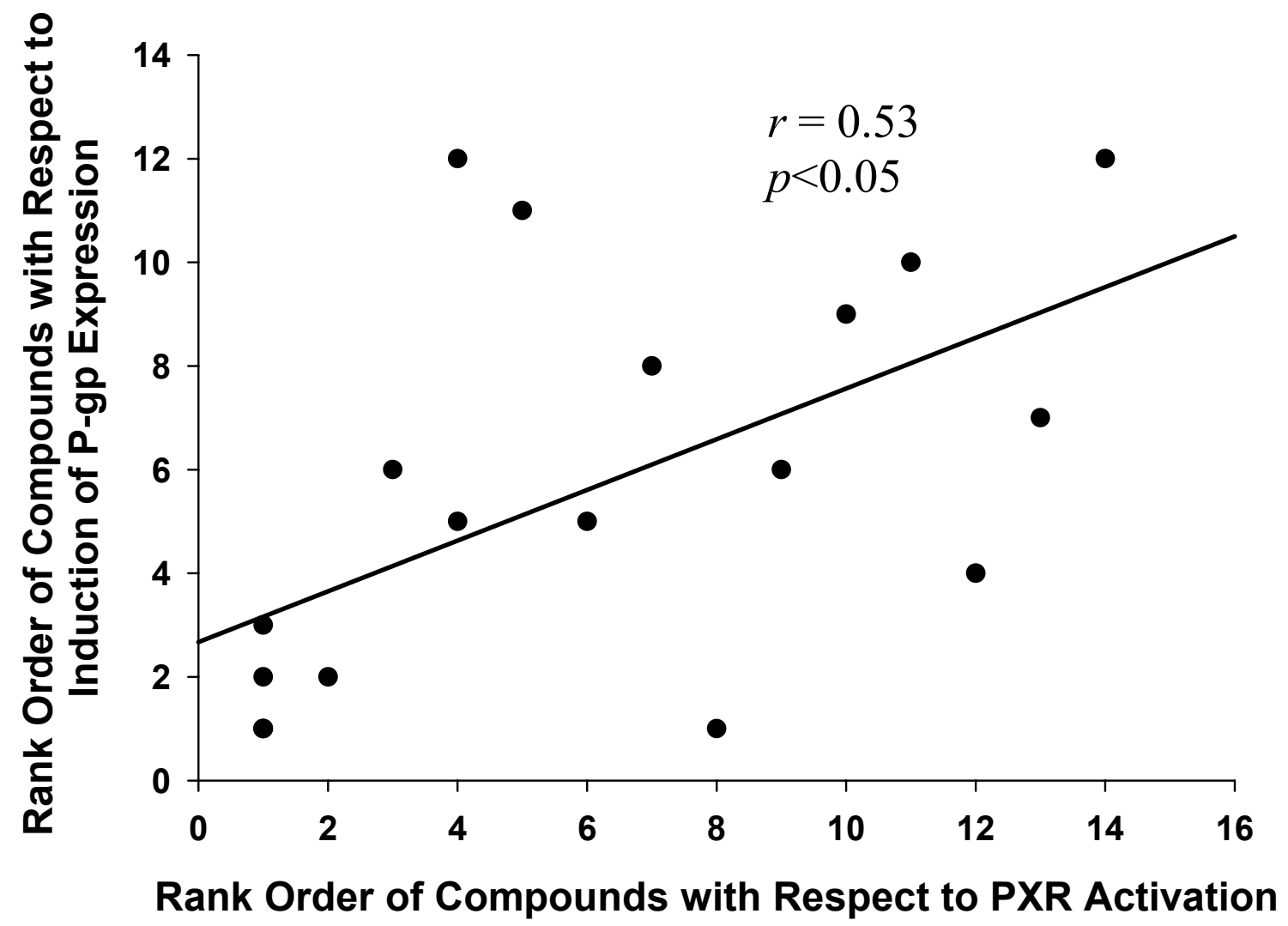

Figure 4-6 Correlation between the rank order for PXR Activation and Induction of P-gp expression 


\subsection{Discussion}

The present study demonstrates that LS174T cells can be used as a model cell line to screen for drugs that can induce P-gp and/or CYP3A. By using a model inducer, rifampin, we have shown increased expression of P-gp in LS147T cells that was dose (Figure 4.1) and time dependent. Schuetz et al. [16] have also shown increased expression of P-gp and CYP3A4 by immunoblot analysis to be dose dependent in LS180 cells. We were not able to detect CYP3A4 protein by immunoblotting in these cells before or after treatment with rifampin. However, CYP3A activity was induced in a dose dependent manner following $72 \mathrm{~h}$ of rifampin treatment (data not shown). The inability to detect protein by immunoblotting was most likely due to the relative insensitivity of western blotting as compared to activity measurements of formation of 1'-OH MDZ. CYP3A activity was completely inhibited in the presence of $10 \mu \mathrm{M}$ ketoconazole, an inhibitior of CYP3A (Figure 4.4).

Midazolam is a substrate for all CYP3A isoforms (CYP3A4, 5 and 7), however, the metabolic capabilities differ between the isoforms with CYP3A4 being the most active or equal to CYP3A5 and CYP3A7 having lower metabolic capacity [102]. CYP3A5 is not induced by rifampin in human hepatocytes, colon carcinoma cell lines [16] or in human lymphocytes [103]. Moreover, the PXR binding domain is absent in the 5' promoter region of the CYP3A5 gene [104]. CYP3A7 is mostly found in fetal livers, however, mRNA for CYP3A7 has been detected in adults [16]. In addition, CYP3A7 was not detected in the LS180 colon carcinoma cell line. Even though the identity of the induced CYP3A isoform is not known, lines of evidence aforementioned suggest the 
involvement of CYP3A4 primarily. However, further studies are needed to identify the CYP3A isoform involved.

As MRK-16 anti P-gp antibody recognizes the external epitope of P-gp, it was used in flow cytometry measurements to determine the surface expression of P-gp in LS174T cells, as the induced protein needs to be at the cellular surface to be functional. The fluoresence intensity of vehicle treated cells was compared with that of drug treated cells. The fluoresence intensity in rifampin treated cells was 3.5 fold higher than vehicle treated cells, whereas reserpine induced P-gp expression about 4 fold over control cells (Figure 4.2).

Vinblastine was used as a model substrate to measure P-gp function in LS174T cells. Cellular accumulation of $\left[{ }^{3} \mathrm{H}\right]$-vinblastine was measured in control and rifampin treated cells (Figure 4.3). The accumulation of $\left[{ }^{3} \mathrm{H}\right]$-vinblastine in rifampin treated cells was significantly less than in control cells as P-gp, an efflux transporter, decreased intracellular accumulation. Cyclosporin A (a P-gp inhibitor) treatment significantly increased $\left[{ }^{3} \mathrm{H}\right]$-vinblastine uptake in un-induced cells. Though $\left[{ }^{3} \mathrm{H}\right]$-vinblastine uptake was also increased by CsA in rifampin treated cells, this increase was not statistically significant. In presence of an inhibitor, the uptake in control and treated cells should be comparable as the P-gp activity is being blocked / inhibited. It is unclear why the results were not comparable in our study, but CsA is also a substrate for CYP3A. Since CYP3A was also induced in this cell line, an increase in CsA metabolism could have resulted in less CsA available for inhibition of P-gp.

Geick et al. [27] demonstrated that human $A B C B 1$ gene has a PXR response element in the 5'-upstream region. These investigators reported the presence of PXR 
mRNA in LS174T cells and measured the increased expression of $A B C B 1$ mRNA after exposing the cells to various PXR activators and CYP3A inducers. Recent studies by Synold et al. [24] further support the involvement of PXR in induction of $A B C B 1$ transcription. To determine if PXR activators were able to induce the P-gp expression in LS174T cells, we treated these cells with a total of 18 compounds that had varying affinities for PXR. A positive correlation was noted with a correlation coefficient of 0.53 (Figure. 4.6) when compounds were rank ordered for PXR activation and induction of Pgp). On excluding outliers like hyperforin, troglitazone and taxol from the analysis, the correlation coefficient increased to 0.663 . Troglitazone and hyperforin showed increased affinity for PXR but did not increase (troglitazone) or moderately increased (hyperforin) P-gp expression. The failure of troglitazone and moderate effect of hyperforin to increase P-gp expression may be explained based on the stability of these compounds. The PXR reporter gene assay was carried out for 24 hours whereas the LS174T cells were treated for 72 hours. Because hyperforin and troglitazone are unstable in solution [105;106], this lag in assay measurement times may explain the lack of effect.

Synold et al. [24] have reported a 50 fold activation of SXR by taxol in a reporter gene assay. On the other hand Luo et al. [107] have demonstrated a 4 fold activation of PXR over control after taxol treatment. In our study, taxol activated PXR (2 fold) and induced P-gp expression (4 fold) over control. The reason(s) for differential effect of taxol on P-gp expression as compared to PXR activation are unclear. Involvement of other orphan nuclear receptors apart from PXR or other pathways that could be responsible for induction of P-gp cannot be excluded. 
In conclusion, our results demonstrate that P-gp and CYP3A proteins were induced in LS174T cells. This cell line appears to be a good cell based model for screening compounds for their ability to induce both P-gp and CYP3A proteins. We have shown that there was a correlation between the ability of compounds to activate PXR and to increase the expression of P-gp supporting the involvement of PXR in induction of the $A B C B 1$ gene. 
CHAPTER - V

\section{ADDITIONAL RESULTS}




\subsection{Sialic acid assay to determine the orientation or sidedness of membrane vesicles}

In the case of inside-out vesicles, the cytoplasmic surface of the membrane forms the exterior side of the vesicles. The quality of the inside-out vesicles can be determined by conducting assays to measure the accessibility of markers normally found on the outer surface of the cells. Sialic acid is one such marker that is typically found on the outer surface of the cells [80]. In the case of inside-out vesicles, sialic acid will be present on the interior side of the vesicles and thus not accessible to enzymatic release. Sialidase, which releases sialic acid from the surface, is not able to penetrate the inside-out vesicles and thus, only has access to sialic acid located on right side out vesicles and broken vesicles. Detergents or surfactants can be used to disrupt the vesicles and expose the sialic acid from inside-out vesicles to sialidase. Thus, experiments were carried out with and without Triton X-100 (detergent) to determine the percentage of inside-out vesicles.

A standard curve was generated with $\mathrm{N}$-acetyl neuraminic acid (sialic acid) in concentrations ranging from $20-320 \mu \mathrm{g} / \mathrm{ml}$. The standards and samples were then derivatized as described in the experimental section (chapter 2) and measured using a UV spectrophotometer. The standard curve was validated at low, medium and high concentrations with 6 replicates of each. The $\%$ coefficient of variation $(\% \mathrm{C} . \mathrm{V}$.$) was less$ than $20 \%$ at all three concentrations. On average, placental vesicle samples were found to consist of $18-20 \%$ inside-out vesicles, with the remainder being the right side out or broken vesicles. Though the percent formation of inside-out vesicles was low, it was consistent from sample to sample. 


\subsection{Alkaline phosphatase assay to determine the enrichment of vesicles as well as the orientation of membrane vesicles}

Alkaline phosphatase is a marker enzyme localized in the microvillus membrane

of cells and can be used to determine the enrichment of microvillus membrane when isolating membranes from cells or tissue homogenates [79]. Alkaline phosphatase catalyzes the formation of $p$-nitrophenol from $p$-nitrophenylphosphate [83]. The reaction is performed in alkaline $\mathrm{pH}$ as $p$-nitrophenol is colorless in acidic $\mathrm{pH}$ but forms a yellow color in alkaline $\mathrm{pH}$, due to the $p$-nitrophenoxide ion. This assay was used to measure the enrichment of the microvillus membrane in vesicle preparations as well as to determine the orientation of membrane vesicles.

Alkaline phosphatase activity was determined in various fractions saved from the process of isolating membrane vesicles from placental tissue. It was observed that the formation of $p$-nitrophenol was about 8.5 fold higher in the final microvillus membrane fraction as compared to the first homogenate. Assuming the alkaline phosphatase activity in homogenate 1 as $100 \%$, it was noted that supernatant 1 obtained from the centrifugation of homogenate 1 exhibited $92 \%$ of the original alkaline phosphatase activity, whereas, homogenate 2 exhibited only $8 \%$ of the original alkaline phosphatase activity. These results suggest that most of the microvillus membrane vesicles were being isolated in first homogenate and there was no need for the second homogenization step, in agreement with results reported by Illsley et al. [79].

This assay was also used to determine the percentage of inside-out vesicles and therefore validate the results of the sialic acid assay. The alkaline phosphatase assay was performed in the presence and absence of detergent and the percentage of inside-out 
vesicles was calculated. Results from this assay were in agreement with the results from sialic acid assay and showed that the percentage of inside-out membrane vesicles was 18$20 \%$.

\subsection{Uptake of radiolabeled substrate in membrane vesicles}

As the substrates used in the uptake assay were observed to bind non-specifically to the filters, experiments were carried out to determine the best method for blocking the non-specific binding of substrate to the filters. Based on literature evidence, $10 \%$ fetal bovine serum, 3\% bovine serum albumin and high concentrations of unlabeled vinblastine were assessed for their ability to block the non-specific binding of vinblastine to the filters. As seen in Table 5.1, the overall binding to glass fiber filters was less than to nitrocellulose filters. In comparing different blocking media, 3\% bovine serum albumin decreased the non-specific binding of radiolabeled vinblastine to less than $10 \%$ of the radioactivity added, irrespective of the type of filter. Based on this experiment, nitrocellulose filters soaked in 3\% bovine serum albumin were used for the uptake experiments.

To determine the optimum time for incubation of substrate with the vesicles, a time dependent uptake assay was carried out using vinblastine as the substrate. The reactions were quenched at different time points in the presence and absence of ATP and uptake calculated. As vinblastine is highly hydrophobic in nature, a plateau in rate of

uptake was observed within 2 min and which remained constant for 15 min (Figure 5.1). A convenient time point of 10 min was therefore chosen for further studies. 
To determine if vinblastine uptake was mediated by P-gp without any interference from $\mathrm{ABCP}$, vinblastine uptake was measured in the presence of $\mathrm{P}$-gp and $\mathrm{ABCP}$ inhibitors. Vinblastine uptake was inhibited by verapamil (10 and $100 \mu \mathrm{M})$, a P-gp inhibitor but not by FTC $(10 \mu \mathrm{M})$, an ABCP inhibitor, suggesting that vinblastine uptake was mediated by P-gp and not by ABCP. Similarly mitoxantrone uptake was measured in the presence of these same inhibitors. Mitoxantrone uptake was inhibited approximately $65 \%$ by $10 \mu \mathrm{M}$ FTC but less than $10 \%$ by $10 \mu \mathrm{M}$ verapamil, suggesting that mitoxantrone uptake is primarily mediated by $\mathrm{ABCP}$. Thus, the P-gp mediated uptake of vinblastine was not confounded by effects of $\mathrm{ABCP}$ and likewise, the $\mathrm{ABCP}$ mediated uptake of mitoxantrone was not affected by concurrent mitoxantrone transport by P-gp. 
Table 5-1 Non-specific binding of $\left[{ }^{3} \mathrm{H}\right]$-vinblastine to nitrocellulose and glass fiber $(\mathrm{GF} / \mathrm{F})$ filters and effect of blocking solutions to reduce the non-specific binding

\begin{tabular}{|l|c|c|}
\hline \multicolumn{1}{|c|}{ Treatment } & \multicolumn{2}{|c|}{$\%$ Radioactivity } \\
\cline { 2 - 3 } & Nitrocellulose & GF/F filters \\
\hline $10 \%$ FBS & 42.8 & 8.3 \\
$5 \mu \mathrm{BSA}$ cold VBL for 1 & 9.6 & 5.2 \\
hour & 78.5 & 35.4 \\
$5 \mu \mathrm{M}$ VBL for 5 min \\
$\begin{array}{l}1 \mu \mathrm{M} \text { VBL in quench } \\
\text { buffer }\end{array}$ & 84.2 & 43.9 \\
$\begin{array}{l}10 \mu \mathrm{M} \text { VBL in quench } \\
\text { buffer }\end{array}$ & 76.5 & 22.8 \\
\hline
\end{tabular}




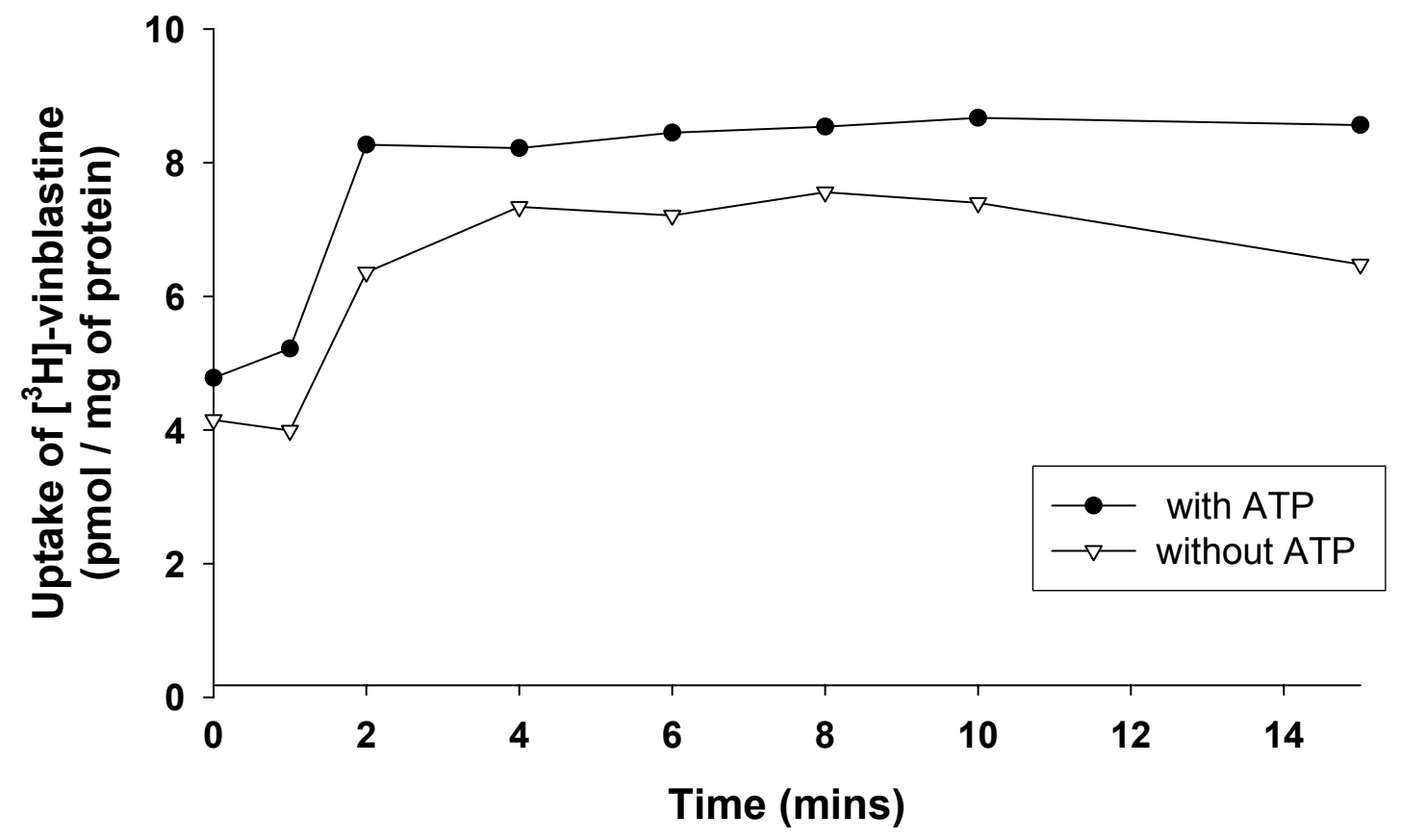

Figure 5-1 Time course of $\left[{ }^{3} \mathrm{H}\right]$-vinblastine uptake in membrane vesicles

Membrane vesicles were incubated with tritiated vinblastine in transport buffer at $37^{\circ} \mathrm{C}$ for various time intervals. The open symbols represent uptake in the presence of $4 \mathrm{mM}$ ATP and the closed symbols in the absence of ATP. Data represent means of duplicate determinations. 


\subsection{Induction studies in BeWo and JAR placental cells}

P-gp from human intestinal cells is known to be induced by PXR ligands such as rifampin [16]. It has also been shown to be induced in human hepatocytes by some Ah receptor ligands like 3-methylcholanthrene [17]. With this background, we hypothesized that placental P-gp could also be induced by either PXR or Ah receptor ligands. To determine the inducibility of placental P-gp, the placental choriocarcinoma cell lines JAR and BeWo were used as model systems for the human placenta.

After culturing the BeWo cells to $50 \%$ confluency, they were treated with increasing concentrations of rifampin and at the end of $72 \mathrm{~h}$, the cells were lysed. Similarly, JAR cells were treated with rifampin and clotriamazole (PXR ligands) and 3$\mathrm{MC}$ and benzo-[a]-pyrene (Ah receptor ligands) at 50\% confluency and at the end of 72 $\mathrm{h}$, the cells were lysed. The cell lysates were analyzed for P-gp expression by immunoblotting as described in the experimental section (chapter 2). Little expression of P-gp was detected in BeWo cells and expression was not induced by rifampin treatment. In the case of JAR cells, no P-gp expression was detected in either control or treated cells.

When the JAR cell lysates were probed for ABCP expression, high endogenous expression of $\mathrm{ABCP}$ was noted in control cells but expression did not increase after treatment with various xenobiotics (Figure 5.2 and 5.3). A polyclonal, $\mathrm{ABCP}$ antibody, anti-MXR 87405 (gift from Dr. Susan Bates, NIH) was used as a primary antibody for the blot shown in Figure 5.2. Use of this antibody resulted in substantial background signal and for unknown reasons did not recognize $\mathrm{ABCP}$ in human placental samples. When the BXP-21 antibody from Signet Laboratories was used as a primary antibody for 
$\mathrm{ABCP}$ (Figure 5.3), we were able to detect $\mathrm{ABCP}$ in both human placental samples as well as in JAR placental cell lysates. Since BXP-21 gave very little background signal and also was able to detect $\mathrm{ABCP}$ in human placental samples, this primary antibody was used for immunoblotting studies of ABCP in JAR cells and in human placental samples. However it was observed that the ABCP protein in human placental samples migrated differently than the ABCP in the JAR placental cell lysates. These differences could be due to the differences in post-translational modifications, such as glycosylation. A lower molecular weight band of $\mathrm{ABCP}$ was reported by Litman et al. [73] when a mitoxantrone selected colon carcinoma cell line which overexpresses ABCP, was treated with tunicamycin (inhibitor of $N$-glycosylation) and $N$-glycosidase F. These results suggest that $\mathrm{ABCP}$ undergoes post-translational modifications at the $N$-linked glycosylation sites in this cell line. Whether the ABCP protein in human placenta or the placental cell lines studied by us undergoes such glycosylation is not known. 


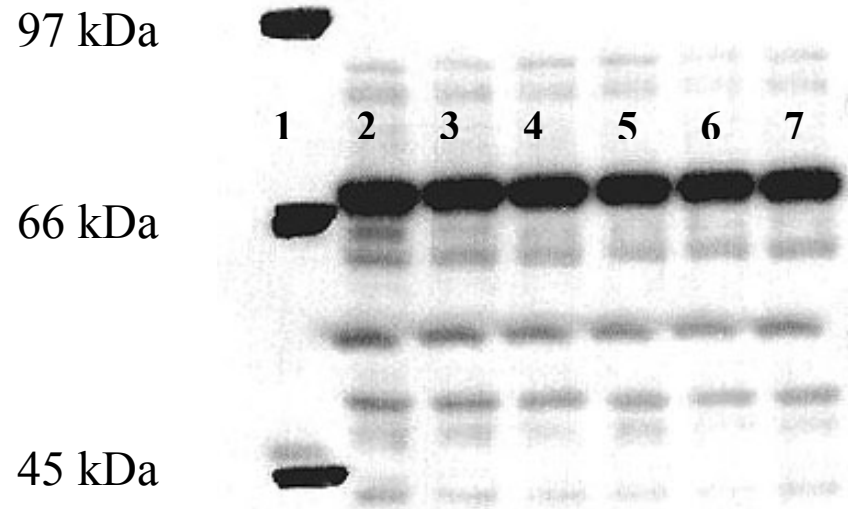

Figure 5-2 Immunoblot of ABCP from JAR placental cell lysates probed with antiMXR antibody 87405

Lane 1 contains the molecular weight markers and lanes 2-7 are JAR cell lysates after treatment with various xenobiotics. Lane 2: cells with no treatment, 3: acetone, 4: DMSO, 5: 3-Methylcholanthrene, 6 and 7: $50 \mu \mathrm{M}$ and $10 \mu \mathrm{M}$ Benzo-[a]-pyrene, respectively. 


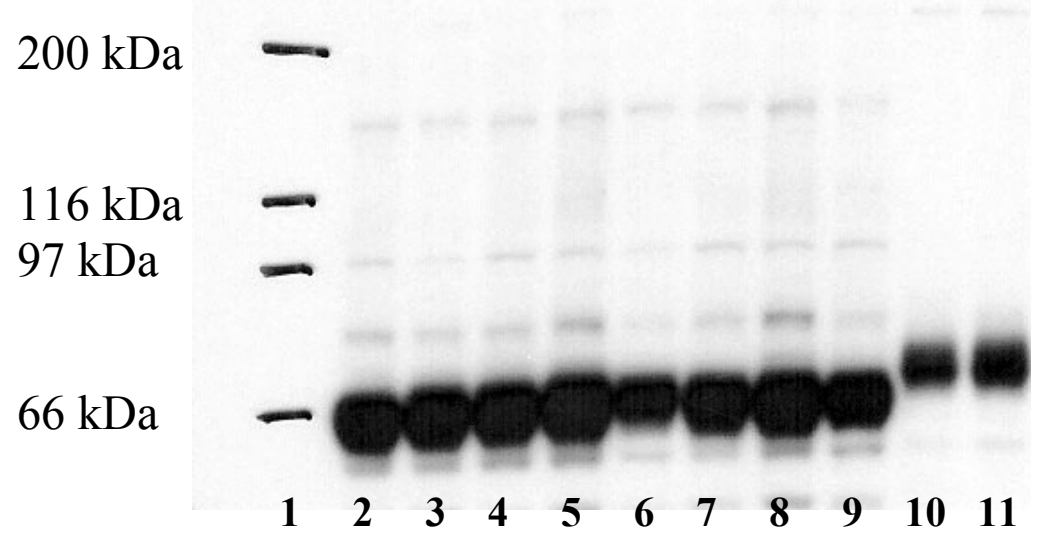

Figure 5-3 Immunoblot of ABCP from human placental samples and JAR placental cell lysates probed with BXP-21 primary antibody for $\mathrm{ABCP}$

Lanes 2-9 are human placental vesicle samples and lanes 10 and 11 are JAR cell lysates after DMSO and $10 \mu \mathrm{M}$ rifampin treatment, respectively. The ABCP protein in JAR cell lysates migrated higher than $\mathrm{ABCP}$ in human placental vesicles. 


\section{CHAPTER -VI}

\section{SUMMARY AND CONCLUSIONS}


The placenta is a vital link between mother and fetus and plays an important role in modulating the passage of xenobiotics from mother to fetus. Generally, it is preferred that the fetus not be exposed to drugs ingested by the mother during pregnancy; however, in certain situations such as HIV-infection, fetal transfer of drugs is desired to achieve a positive therapeutic outcome. Most HIV protease inhibitors are substrates for P-gp and thus potentially effluxed at the placental level back to the mother, decreasing their therapeutic efficacy in treating the fetus. P-gp is known to be inducible by xenobiotics and thus, if placental P-gp induction occurred, a further decrease in the transfer of these drugs across the placenta would occur. Thus, understanding the inducibility of placental P-gp is important to be able to predict the therapeutic efficacy of drugs in treating fetal maladies and for dosage optimization.

The placenta contains enzymes and transporters that can, respectively, metabolize xenobiotics or cause their efflux back to the mother. Most placental metabolism research has been focused on the inducibility of placental oxidative enzymes in mothers who smoke during pregnancy. Cigarette smoke contains polycyclic aromatic hydrocarbons (PAHs) which are metabolized to carcinogenic compounds by CYP1A1. CYP1A1 is induced in response to cigarette smoking in human placenta. P-gp, an efflux transporter, present in the placenta is also known to be induced by PAHs in hepatocytes, however, whether it is induced in placenta was heretofore unknown. We report here the effect of smoking on expression and function of P-gp in the human placenta. P-gp function was measured as the uptake of vinblastine in membrane vesicles prepared from human placenta. To assure that vinblastine transport was being measured and not nonproductive binding, a series of initial uptake experiments were carried out in increasing 
concentrations of sucrose. Results of these experiments demonstrated that transport was intravesicular. Additional experiments using the P-gp inhibitor verapamil demonstrated that the observed vinblastine transport was P-gp mediated. Finally, it was noted that vinblastine transport was comparable between smokers and non-smokers. Similarly no significant difference was observed in P-gp expression between the two groups. However, a substantial inter-individual difference was observed that was not attributable to the effects of smoking. In view of the polymorphisms existing in the $A B C B 1$ gene that can cause altered expression and function of P-gp, determination of P-gp genotype may be necessary to provide insight into the substantial inter-individual variation.

The effect of smoking on another efflux transporter, $\mathrm{ABCP}$, was studied in human placenta. This is the first report of $\mathrm{ABCP}$ functional studies in human tissue and its regulation by smoking. Since $\mathrm{ABCP}$ is a half transporter, it is assumed to require dimerization to become a functional protein. Immunblotting studies for $\mathrm{ABCP}$ were carried out with and without dithiothreitol (DTT), a reducing agent, to determine if $\mathrm{ABCP}$ existed as a dimer in non-reducing conditions. A band was observed at $70 \mathrm{kDa}$ in reducing conditions and at $140 \mathrm{kDa}$ under non-reducing conditions. These results suggest that $\mathrm{ABCP}$ exists as a dimer. To further confirm the need for dimerization of $\mathrm{ABCP}$ for functionality, uptake studies in the presence and absence of DTT were carried out. The ATP dependent uptake of mitoxantrone, an ABCP substrate, was decreased about $67 \%$ in the presence of DTT as compared to the absence of DTT. This confirms that $\mathrm{ABCP}$ requires dimerization to become a functional protein. When uptake of mitoxantrone was determined in the presence of $\mathrm{ABCP}$ and P-gp inhibitors, it was observed that mitoxantrone uptake was primarily carried out by $\mathrm{ABCP}$, confirming that 
mitoxantrone was a good substrate for measuring the function of $\mathrm{ABCP}$ in vesicles which also express P-gp. No statistical difference was observed in either function or expression of $\mathrm{ABCP}$ between smokers and non-smokers. Mutations have also been reported in $\mathrm{ABCP}$ overexpressing cell lines, however, whether these mutations exist in humans and can affect the level of expression and function of $\mathrm{ABCP}$ is not known yet. Hence in addition to P-gp, genotyping studies for $\mathrm{ABCP}$ would also be beneficial in understanding inter-individual differences.

In agreement with literature evidence, placental CYP1A1 activity was induced in smokers as compared to non-smokers. No correlation in activity was observed between CYP1A1 and P-gp in human placenta. It has previously been established that the PAH benzo-[a]-pyrene, a substrate for CYP1A1, is also transported by P-gp. Thus, based on our observations, it can be implied that the women who smoke during pregnancy and have high CYP1A1 activity but low P-gp activity, produce more toxic metabolites of PAH from the cigarette smoke and their fetuses probably have a higher risk of fetal exposure to these carcinogenic or mutagenic metabolites. We now know that $\mathrm{ABCP}$ is functional in human placenta and probably also plays a protective role by preventing the placental transfer of xenobiotics. It is not known whether PAHs are substrates for ABCP. ABCP was not affected by maternal smoking status in this study and the clinical significance of this finding is not known.

P-gp plays a role in the absorption, distribution and excretion of drugs. It has broad substrate specificity and due to its efflux nature, leads to the decreased bioavailability of its substrates. In addition, it is usually co-localized with CYP3A4, an important drug-metabolizing enzyme. Furthermore, these two proteins have common 
substrates and inducers. Thus, both these proteins can act additively to decrease the therapeutic efficacy of common substrates and can lead to drug - drug interactions. Since P-gp and CYP3A4 are both expressed in intestine and have common substrates, we have evaluated LS174T cells, an intestinal cell line, as a model cell line to screen compounds for their ability to induce P-gp and CYP3A4 in hopes of better predicting drug - drug interactions.

Using rifampin as a model inducer, the induction of P-gp and CYP3A4 was studied in LS174T cells. A dose and time dependent induction of P-gp expression was noted in these cells. Using flow cytometry and MRK-16, a P-gp antibody that recognizes an external epitope of P-gp, increased surface expression of P-gp was detected in LS174T cells after rifampin treatment. This suggests the presence of induced protein at the cell surface where its presence would be required for efflux of drugs out of the cells. Decreased vinblastine uptake after rifampin treatment as compared to control cells indicated induction of the functional activity of P-gp. The studies herein report for the first time, induction of CYP3A activity in LS174T cells, though increased expression of CYP3A4 has been reported in LS180 cells. A four fold induction of CYP3A activity, assessed by formation of 1' - hydroxymidazolam after rifampin treatment, was noted as compared to control cells and this activity was inhibited more than $90 \%$ by $10 \mu \mathrm{M}$ ketoconazole. These results suggest that LS174T cells can be used as a model cell line to study the induction of P-gp and CYP3A. The isoform of CYP3A induced in these cells, however, remains to be identified.

In addition, we have also compared and correlated the ability of compounds to induce P-gp in LS174T cells with their ability to activate PXR in a reporter gene assay. 
The involvement of the nuclear hormone receptor, PXR, in induction of P-gp has been demonstrated; however, it may not be solely responsible for controlling P-gp expression. A positive correlation between the ability of compounds to induce P-gp in LS174T cells and activate PXR was observed, further supporting the role of PXR in P-gp induction. In addition to being induced by PXR ligands, P-gp is also known to be induced by some Ah receptor ligands, however, this induction was not reported to proceed via the Ah receptor pathway. To determine if placental P-gp is inducible by various xenobiotics, the placental choriocarcinoma cell lines, BeWo and JAR were used to study the induction of P-gp. Placental cells were treated with the known inducers of P-gp, rifampin and 3methylcholanthrene. P-gp expression was undetectable in JAR cells, in both control and treated cells, suggesting these compounds did not induce P-gp expression in this placental cell line. Conversely low P-gp expression was detected in BeWo cells but no induction was observed after rifampin treatment. Though induction at the protein level was not detected, it would be useful to perform mRNA studies to determine if induction at the gene level occurred. Since PXR is known to be expressed in a tissue selective manner, determination of whether PXR is expressed in human placenta could also provide valuable insight into our lack of observed induction. 


\section{REFERENCES}


1. Dean M, Rzhetsky A, Allikmets R. The human ATP-binding cassette (ABC) transporter superfamily. Genome Res 2001; 11:1156-1166.

2. Fojo A, Lebo R, Shimizu N, Chin JE, Roninson IB, Merlino GT, Gottesman MM, Pastan I. Localization of multidrug resistance-associated DNA sequences to human chromosome 7. Somat.Cell Mol.Genet. 1986; 12:415-420.

3. Callen DF, Baker E, Simmers RN, Seshadri R, Roninson IB. Localization of the human multiple drug resistance gene, MDR1, to 7q21.1. Hum. Genet. 1987; 77:142-144.

4. Ambudkar SV, Dey S, Hrycyna CA, Ramachandra M, Pastan I, Gottesman MM. Biochemical, cellular, and pharmacological aspects of the multidrug transporter. Annu.Rev.Pharmacol.Toxicol. 1999; 39:361-398.

5. Ambudkar SV, Cardarelli CO, Pashinsky I, Stein WD. Relation between the turnover number for vinblastine transport and for vinblastine-stimulated ATP hydrolysis by human P-glycoprotein. J.Biol.Chem. 1997; 272:21160-21166.

6. Shapiro AB, Ling V. Stoichiometry of coupling of rhodamine 123 transport to ATP hydrolysis by P-glycoprotein. Eur.J.Biochem. 1998; 254:189-193.

7. Sauna ZE, Ambudkar SV. Evidence for a requirement for ATP hydrolysis at two distinct steps during a single turnover of the catalytic cycle of human Pglycoprotein. Proc.Natl.Acad.Sci.U.S.A 2000; 97:2515-2520.

8. Gottesman MM, Fojo T, Bates SE. Multidrug resistance in cancer: role of ATPdependent transporters. Nat.Rev.Cancer 2002; 2:48-58.

9. Cordon-Cardo C, O'Brien JP, Boccia J, Casals D, Bertino JR, Melamed MR. Expression of the multidrug resistance gene product (P-glycoprotein) in human normal and tumor tissues. J.Histochem.Cytochem. 1990; 38:1277-1287.

10. Smit JW, Huisman MT, van Tellingen O, Wiltshire HR, Schinkel AH. Absence or pharmacological blocking of placental P-glycoprotein profoundly increases fetal drug exposure. J.Clin.Invest 1999; 104:1441-1447.

11. Kim RB, Fromm MF, Wandel C, Leake B, Wood AJ, Roden DM, Wilkinson GR. The drug transporter P-glycoprotein limits oral absorption and brain entry of HIV1 protease inhibitors. J.Clin.Invest 1998; 101:289-294.

12. Kwei GY, Alvaro RF, Chen Q, Jenkins HJ, Hop CE, Keohane CA, Ly VT, Strauss JR, Wang RW, Wang Z, Pippert TR, Umbenhauer DR. Disposition of ivermectin and cyclosporin A in CF-1 mice deficient in mdrla P-glycoprotein. Drug Metab Dispos. 1999; 27:581-587. 
13. Lankas GR, Wise LD, Cartwright ME, Pippert T, Umbenhauer DR. Placental Pglycoprotein deficiency enhances susceptibility to chemically induced birth defects in mice. Reprod.Toxicol. 1998; 12:457-463.

14. Litman T, Druley TE, Stein WD, Bates SE. From MDR to MXR: new understanding of multidrug resistance systems, their properties and clinical significance. Cell Mol.Life Sci. 2001; 58:931-959.

15. Martin C, Berridge G, Higgins CF, Mistry P, Charlton P, Callaghan R. Communication between multiple drug binding sites on P-glycoprotein. Mol.Pharmacol. 2000; 58:624-632.

16. Schuetz EG, Beck WT, Schuetz JD. Modulators and substrates of P-glycoprotein and cytochrome P4503A coordinately up-regulate these proteins in human colon carcinoma cells. Mol.Pharmacol. 1996; 49:311-318.

17. Schuetz EG, Schuetz JD, Thompson MT, Fisher RA, Madariage JR, Strom SC. Phenotypic variability in induction of P-glycoprotein mRNA by aromatic hydrocarbons in primary human hepatocytes. Mol.Carcinog. 1995; 12:61-65.

18. Huang L, Wring SA, Woolley JL, Brouwer KR, Serabjit-Singh C, Polli JW. Induction of P-glycoprotein and cytochrome P450 3A by HIV protease inhibitors. Drug Metab Dispos. 2001; 29:754-760.

19. Cvetkovic M, Leake B, Fromm MF, Wilkinson GR, Kim RB. OATP and Pglycoprotein transporters mediate the cellular uptake and excretion of fexofenadine. Drug Metab Dispos. 1999; 27:866-871.

20. de Lannoy IA, Silverman M. The MDR1 gene product, P-glycoprotein, mediates the transport of the cardiac glycoside, digoxin. Biochem.Biophys.Res.Commun. 1992; 189:551-557.

21. Schinkel AH, Wagenaar E, van Deemter L, Mol CA, Borst P. Absence of the mdr1a P-Glycoprotein in mice affects tissue distribution and pharmacokinetics of dexamethasone, digoxin, and cyclosporin A. J.Clin.Invest 1995; 96:1698-1705.

22. Greiner B, Eichelbaum M, Fritz P, Kreichgauer HP, von Richter O, Zundler J, Kroemer HK. The role of intestinal P-glycoprotein in the interaction of digoxin and rifampin. J.Clin.Invest 1999; 104:147-153.

23. Hamman MA, Bruce MA, Haehner-Daniels BD, Hall SD. The effect of rifampin administration on the disposition of fexofenadine. Clin.Pharmacol.Ther. 2001; 69:114-121.

24. Synold TW, Dussault I, Forman BM. The orphan nuclear receptor SXR coordinately regulates drug metabolism and efflux. Nat.Med. 2001; 7:584-590. 
25. Minuzzo M, Marchini S, Broggini M, Faircloth G, D'Incalci M, Mantovani R. Interference of transcriptional activation by the antineoplastic drug ecteinascidin743. Proc.Natl.Acad.Sci.U.S.A 2000; 97:6780-6784.

26. Jin S, Gorfajn B, Faircloth G, Scotto KW. Ecteinascidin 743, a transcriptiontargeted chemotherapeutic that inhibits MDR1 activation.

Proc.Natl.Acad.Sci.U.S.A 2000; 97:6775-6779.

27. Geick A, Eichelbaum M, Burk O. Nuclear receptor response elements mediate induction of intestinal MDR1 by rifampin. J.Biol.Chem. 2001; 276:14581-14587.

28. Schuetz EG, Furuya KN, Schuetz JD. Interindividual variation in expression of Pglycoprotein in normal human liver and secondary hepatic neoplasms.

J.Pharmacol.Exp.Ther. 1995; 275:1011-1018.

29. Zhou-Pan XR, Seree E, Zhou XJ, Placidi M, Maurel P, Barra Y, Rahmani R. Involvement of human liver cytochrome P450 3A in vinblastine metabolism: drug interactions. Cancer Res 1993; 53:5121-5126.

30. Harris JW, Rahman A, Kim BR, Guengerich FP, Collins JM. Metabolism of taxol by human hepatic microsomes and liver slices: participation of cytochrome P450 3A4 and an unknown P450 enzyme. Cancer Res 1994; 54:4026-4035.

31. Cardarelli CO, Aksentijevich I, Pastan I, Gottesman MM. Differential effects of P-glycoprotein inhibitors on NIH3T3 cells transfected with wild-type (G185) or mutant (V185) multidrug transporters. Cancer Res. 1995; 55:1086-1091.

32. Mickley LA, Lee JS, Weng Z, Zhan Z, Alvarez M, Wilson W, Bates SE, Fojo T. Genetic polymorphism in MDR-1: a tool for examining allelic expression in normal cells, unselected and drug-selected cell lines, and human tumors. Blood 1998; 91:1749-1756.

33. Hoffmeyer S, Burk O, von Richter O, Arnold HP, Brockmoller J, Johne A, Cascorbi I, Gerloff T, Roots I, Eichelbaum M, Brinkmann U. Functional polymorphisms of the human multidrug-resistance gene: multiple sequence variations and correlation of one allele with P-glycoprotein expression and activity in vivo. Proc.Natl.Acad.Sci.U.S.A 2000; 97:3473-3478.

34. Tanabe M, Ieiri I, Nagata N, Inoue K, Ito S, Kanamori Y, Takahashi M, Kurata Y, Kigawa J, Higuchi S, Terakawa N, Otsubo K. Expression of P-glycoprotein in human placenta: relation to genetic polymorphism of the multidrug resistance (MDR)-1 gene. J.Pharmacol.Exp.Ther. 2001; 297:1137-1143.

35. Kim RB, Leake BF, Choo EF, Dresser GK, Kubba SV, Schwarz UI, Taylor A, Xie HG, McKinsey J, Zhou S, Lan LB, Schuetz JD, Schuetz EG, Wilkinson GR. Identification of functionally variant MDR1 alleles among European Americans and African Americans. Clin.Pharmacol.Ther. 2001; 70:189-199. 
36. Allikmets R, Schriml LM, Hutchinson A, Romano-Spica V, Dean M. A human placenta-specific ATP-binding cassette gene (ABCP) on chromosome 4q22 that is involved in multidrug resistance. Cancer Res. 1998; 58:5337-5339.

37. Doyle LA, Yang W, Abruzzo LV, Krogmann T, Gao Y, Rishi AK, Ross DD. A multidrug resistance transporter from human MCF-7 breast cancer cells. Proc.Natl.Acad.Sci.U.S.A 1998; 95:15665-15670.

38. Miyake K, Mickley L, Litman T, Zhan Z, Robey R, Cristensen B, Brangi M, Greenberger L, Dean M, Fojo T, Bates SE. Molecular cloning of cDNAs which are highly overexpressed in mitoxantrone-resistant cells: demonstration of homology to ABC transport genes. Cancer Res. 1999; 59:8-13.

39. Kage K, Tsukahara S, Sugiyama T, Asada S, Ishikawa E, Tsuruo T, Sugimoto Y. Dominant-negative inhibition of breast cancer resistance protein as drug efflux pump through the inhibition of S-S dependent homodimerization. Int.J.Cancer 2002; 97:626-630.

40. Ross DD, Yang W, Abruzzo LV, Dalton WS, Schneider E, Lage H, Dietel M, Greenberger L, Cole SP, Doyle LA. Atypical multidrug resistance: breast cancer resistance protein messenger RNA expression in mitoxantrone-selected cell lines. J.Natl.Cancer Inst. 1999; 91:429-433.

41. Maliepaard M, van Gastelen MA, de Jong LA, Pluim D, van Waardenburg RC, Ruevekamp-Helmers MC, Floot BG, Schellens JH. Overexpression of the BCRP/MXR/ABCP gene in a topotecan-selected ovarian tumor cell line. Cancer Res. 1999; 59:4559-4563.

42. Nakatomi K, Yoshikawa M, Oka M, Ikegami Y, Hayasaka S, Sano K, Shiozawa K, Kawabata S, Soda H, Ishikawa T, Tanabe S, Kohno S. Transport of 7-ethyl-10hydroxycamptothecin (SN-38) by breast cancer resistance protein ABCG2 in human lung cancer cells. Biochem.Biophys.Res.Commun. 2001; 288:827-832.

43. Robey RW, Honjo Y, van de LA, Miyake K, Regis JT, Litman T, Bates SE. A functional assay for detection of the mitoxantrone resistance protein, MXR (ABCG2). Biochim.Biophys.Acta 2001; 1512:171-182.

44. Rabindran SK, He H, Singh M, Brown E, Collins KI, Annable T, Greenberger LM. Reversal of a novel multidrug resistance mechanism in human colon carcinoma cells by fumitremorgin C. Cancer Res. 1998; 58:5850-5858.

45. de Bruin M, Miyake K, Litman T, Robey R, Bates SE. Reversal of resistance by GF120918 in cell lines expressing the ABC half-transporter, MXR. Cancer Lett. 1999; 146:117-126.

46. He H, Rabindran SG, Greenberger LM, Carter GT. Fumitremorgin C analogs that reverse mitoxantrone resistance in human colon carcinoma cells. Med.Chem.Res 1999; 9:424-437. 
47. Imai $\mathrm{Y}$, Tsukahara $\mathrm{S}$, Ishikawa $\mathrm{E}$, Tsuruo $\mathrm{T}$, Sugimoto $\mathrm{Y}$. Estrone and 17 betaestradiol reverse breast cancer resistance protein- mediated multidrug resistance. Jpn.J.Cancer Res. 2002; 93:231-235.

48. Rocchi E, Khodjakov A, Volk EL, Yang CH, Litman T, Bates SE, Schneider E. The product of the $\mathrm{ABC}$ half-transporter gene $\mathrm{ABCG} 2$ (BCRP/MXR/ABCP) is expressed in the plasma membrane. Biochem.Biophys.Res.Commun. 2000; 271:42-46.

49. Maliepaard M, Scheffer GL, Faneyte IF, van Gastelen MA, Pijnenborg AC, Schinkel AH, van de Vijver MJ, Scheper RJ, Schellens JH. Subcellular localization and distribution of the breast cancer resistance protein transporter in normal human tissues. Cancer Res. 2001; 61:3458-3464.

50. Allen JD, Brinkhuis RF, Wijnholds J, Schinkel AH. The mouse Bcrp1/Mxr/Abcp gene: amplification and overexpression in cell lines selected for resistance to topotecan, mitoxantrone, or doxorubicin. Cancer Res. 1999; 59:4237-4241.

51. Jonker JW, Smit JW, Brinkhuis RF, Maliepaard M, Beijnen JH, Schellens JH, Schinkel AH. Role of breast cancer resistance protein in the bioavailability and fetal penetration of topotecan. J.Natl.Cancer Inst. 2000; 92:1651-1656.

52. Eisenblatter T, Galla HJ. A new multidrug resistance protein at the blood-brain barrier. Biochem.Biophys.Res.Commun. 2002; 293:1273-1278.

53. Honjo Y, Hrycyna CA, Yan QW, Medina-Perez WY, Robey RW, van de LA, Litman T, Dean M, Bates SE. Acquired mutations in the MXR/BCRP/ABCP gene alter substrate specificity in MXR/BCRP/ABCP-overexpressing cells. Cancer Res. 2001; 61:6635-6639.

54. Allen JD, Jackson SC, Schinkel AH. A mutation hot spot in the Bcrp1 (Abcg2) multidrug transporter in mouse cell lines selected for Doxorubicin resistance. Cancer Res. 2002; 62:2294-2299.

55. Zamber CP, Lamba JK, Yasuda K, Farnum J, Thummel K, Schuetz JD, Schuetz EG. Natural allelic variants of breast cancer resistance protein (BCRP) and their relationship to BCRP expression in human intestine

1. Pharmacogenetics 2003; 13:19-28.

56. Pasanen M, Taskinen T, Sotaniemi EA, Kairaluoma M, Pelkonen O. Inhibitor panel studies of human hepatic and placental cytochrome P-450- associated monooxygenase activities. Pharmacol.Toxicol. 1988; 62:311-317.

57. Pasanen M. The expression and regulation of drug metabolism in human placenta. Adv.Drug Deliv.Rev. 1999; 38:81-97. 
58. Quattrochi LC, Pendurthi UR, Okino ST, Potenza C, Tukey RH. Human cytochrome P-450 4 mRNA and gene: part of a multigene family that contains Alu sequences in its mRNA. Proc.Natl.Acad.Sci.U.S.A 1986; 83:6731-6735.

59. Miners JO, McKinnon RA. CYP1A.In: Metabolic Drug Interactions eds Levy RH, Thummel K, Trager WF, Hansten PD, Eichelbaum M, Philadelphia: Lippincott Williams \& Wilkins, 2000: 61-73.

60. Hakkola J, Raunio H, Purkunen R, Pelkonen O, Saarikoski S, Cresteil T, Pasanen M. Detection of cytochrome P450 gene expression in human placenta in first trimester of pregnancy. Biochem.Pharmacol. 1996; 52:379-383.

61. Hakkola J, Pasanen M, Hukkanen J, Pelkonen O, Maenpaa J, Edwards RJ, Boobis AR, Raunio H. Expression of xenobiotic-metabolizing cytochrome P450 forms in human full-term placenta. Biochem.Pharmacol. 1996; 51:403-411.

62. Pasanen M, Pelkonen O. Xenobiotic and steroid-metabolizing monooxygenases catalysed by cytochrome P450 and glutathione S-transferase conjugations in the human placenta and their relationships to maternal cigarette smoking. Placenta 1990; 11:75-85.

63. Juchau MR. Human placental hydroxylation of 3,4-benzpyrene during early gestation and at term. Toxicol.Appl.Pharmacol. 1971; 18:665-675.

64. Pasanen M, Stenback F, Park SS, Gelboin HV, Pelkonen O. Immunohistochemical detection of human placental cytochrome P-450associated mono-oxygenase system inducible by maternal cigarette smoking. Placenta 1988; 9:267-275.

65. McRobie DJ, Glover DD, Tracy TS. Regiospecificity of placental metabolism by cytochromes P450 and glutathione S-transferase. Gynecol.Obstet.Invest 1996; 42:154-158.

66. Pathology of the Human Placenta, Third Edition, New York: Springer-Verlag, 2002.

67. Sugawara I, Kataoka I, Morishita Y, Hamada H, Tsuruo T, Itoyama S, Mori S. Tissue distribution of P-glycoprotein encoded by a multidrug-resistant gene as revealed by a monoclonal antibody, MRK 16. Cancer Res. 1988; 48:1926-1929.

68. Nakamura Y, Ikeda S, Furukawa T, Sumizawa T, Tani A, Akiyama S, Nagata Y. Function of P-glycoprotein expressed in placenta and mole.

Biochem.Biophys.Res.Commun. 1997; 235:849-853.

69. Utoguchi N, Chandorkar GA, Avery M, Audus KL. Functional expression of Pglycoprotein in primary cultures of human cytotrophoblasts and BeWo cells. Reprod.Toxicol. 2000; 14:217-224. 
70. Ushigome F, Takanaga H, Matsuo H, Yanai S, Tsukimori K, Nakano H, Uchiumi T, Nakamura T, Kuwano M, Ohtani H, Sawada Y. Human placental transport of vinblastine, vincristine, digoxin and progesterone: contribution of P-glycoprotein. Eur.J.Pharmacol. 2000; 408:1-10.

71. St Pierre MV, Serrano MA, Macias RI, Dubs U, Hoechli M, Lauper U, Meier PJ, Marin JJ. Expression of members of the multidrug resistance protein family in human term placenta. Am.J.Physiol Regul.Integr.Comp Physiol 2000; 279:R1495R1503.

72. Pascolo L, Fernetti C, Garcia-Mediavilla MV, Ostrow JD, Tiribelli C. Mechanisms for the transport of unconjugated bilirubin in human trophoblastic BeWo cells. FEBS Lett. 2001; 495:94-99.

73. Litman T, Jensen U, Hansen A, Covitz K, Zhan Z, Fetsch P, Abati A, Hansen P, Horn T, Skovsgaard T, Bates S. Use of peptide antibodies to probe for the mitoxantrone resistance-associated protein MXR/BCRP/ABCP/ABCG2. Biochim.Biophys.Acta 2002; 1565:6.

74. Bailey-Dell KJ, Hassel B, Doyle LA, Ross DD. Promoter characterization and genomic organization of the human breast cancer resistance protein (ATP-binding cassette transporter G2) gene. Biochim.Biophys.Acta 2001; 1520:234-241.

75. Bush PG, Mayhew TM, Abramovich DR, Aggett PJ, Burke MD, Page KR. A quantitative study on the effects of maternal smoking on placental morphology and cadmium concentration. Placenta 2000; 21:247-256.

76. Gant TW, Silverman JA, Bisgaard HC, Burt RK, Marino PA, Thorgeirsson SS. Regulation of 2-acetylaminofluorene-and 3-methylcholanthrene--mediated induction of multidrug resistance and cytochrome P450IA gene family expression in primary hepatocyte cultures and rat liver. Mol.Carcinog. 1991; 4:499-509.

77. Teeter LD, Petersen DD, Nebert DW, Kuo MT. Murine mdr-1, mdr-2, and mdr-3 gene expression: no coinduction with the Cypla-1 and Nmo-1 genes in liver by 2,3,7,8-tetrachlorodibenzo-p-dioxin. DNA Cell Biol. 1991; 10:433-441.

78. Yeh GC, Lopaczynska J, Poore CM, Phang JM. A new functional role for Pglycoprotein: efflux pump for benzo(alpha)pyrene in human breast cancer MCF-7 cells. Cancer Res. 1992; 52:6692-6695.

79. Illsley NP, Wang ZQ, Gray A, Sellers MC, Jacobs MM. Simultaneous preparation of paired, syncytial, microvillous and basal membranes from human placenta. Biochim.Biophys.Acta 1990; 1029:218-226.

80. Steck TL, Kant JA. Preparation of impermeable ghosts and inside-out vesicles from human erythrocyte membranes. Methods Enzymol. 1974; 31:172-180. 
81. Warren L. The Thiobarbituric Acid Assay of Sialic Acids. J.Biol.Chem. 1959; 234:1971-1975.

82. Aminoff D. Methods for the Quantitative Estimation of $N$ - Acetylneuraminic Acid and their Application of Hydrolysates of Sialomucoids. Biochem.J. 1961; 81:384-391.

83. Bowers GN, Jr., McComb RB. A continuous spectrophotometric method for measuring the activity of serum alkaline phosphatase. Clin.Chem. 1966; 12:70-89.

84. Wheeler R, Neo SY, Chew J, Hladky SB, Barrand MA. Use of membrane vesicles to investigate drug interactions with transporter proteins, P-glycoprotein and multidrug resistance- associated protein. Int.J.Clin.Pharmacol.Ther. 2000; 38:122-129.

85. Vaz AD, Coon MJ, Peegel H, Menon KM. Substituted pyridines: nonsteroidal inhibitors of human placental aromatase cytochrome P-450. Drug Metab Dispos. 1992; 20:108-112.

86. Burke MD, Thompson S, Elcombe CR, Halpert J, Haaparanta T, Mayer RT. Ethoxy-, pentoxy- and benzyloxyphenoxazones and homologues: a series of substrates to distinguish between different induced cytochromes P-450.

Biochem.Pharmacol. 1985; 34:3337-3345.

87. Bellamy WT. P-glycoproteins and multidrug resistance. Annu.Rev.Pharmacol.Toxicol. 1996; 36:161-183.

88. Schinkel AH, Wagenaar E, Mol CA, van Deemter L. P-glycoprotein in the bloodbrain barrier of mice influences the brain penetration and pharmacological activity of many drugs. J.Clin.Invest 1996; 97:2517-2524.

89. Ewart GD, Howells AJ. ABC transporters involved in transport of eye pigment precursors in Drosophila melanogaster. Methods Enzymol. 1998; 292:213-224.

90. Backman JT, Olkkola KT, Neuvonen PJ. Rifampin drastically reduces plasma concentrations and effects of oral midazolam. Clin.Pharmacol.Ther. 1996; 59:713.

91. Watkins PB, Wrighton SA, Schuetz EG, Molowa DT, Guzelian PS. Identification of glucocorticoid-inducible cytochromes P-450 in the intestinal mucosa of rats and man. J.Clin.Invest 1987; 80:1029-1036.

92. Kolars JC, Lown KS, Schmiedlin-Ren P, Ghosh M, Fang C, Wrighton SA, Merion RM, Watkins PB. CYP3A gene expression in human gut epithelium. Pharmacogenetics 1994; 4:247-259.

93. Pichard L, Fabre I, Fabre G, Domergue J, Saint AB, Mourad G, Maurel P. Cyclosporin A drug interactions. Screening for inducers and inhibitors of 
cytochrome P-450 (cyclosporin A oxidase) in primary cultures of human hepatocytes and in liver microsomes. Drug Metab Dispos. 1990; 18:595-606.

94. Villikka K, Kivisto KT, Backman JT, Olkkola KT, Neuvonen PJ. Triazolam is ineffective in patients taking rifampin. Clin.Pharmacol.Ther. 1997; 61:8-14.

95. Wacher VJ, Wu CY, Benet LZ. Overlapping substrate specificities and tissue distribution of cytochrome P450 3A and P-glycoprotein: implications for drug delivery and activity in cancer chemotherapy. Mol.Carcinog. 1995; 13:129-134.

96. Benet LZ, Izumi T, Zhang Y, Silverman JA, Wacher VJ. Intestinal MDR transport proteins and P-450 enzymes as barriers to oral drug delivery. J.Control Release 1999; 62:25-31.

97. Hebert MF, Fisher RM, Marsh CL, Dressler D, Bekersky I. Effects of rifampin on tacrolimus pharmacokinetics in healthy volunteers. J.Clin.Pharmacol. 1999; 39:91-96.

98. Li AP, Reith MK, Rasmussen A, Gorski JC, Hall SD, Xu L, Kaminski DL, Cheng LK. Primary human hepatocytes as a tool for the evaluation of structure-activity relationship in cytochrome P450 induction potential of xenobiotics: evaluation of rifampin, rifapentine and rifabutin. Chem.Biol.Interact. 1997; 107:17-30.

99. Kostrubsky VE, Lewis LD, Strom SC, Wood SG, Schuetz EG, Schuetz JD, Sinclair PR, Wrighton SA, Sinclair JF. Induction of cytochrome P4503A by taxol in primary cultures of human hepatocytes. Arch.Biochem.Biophys. 1998; 355:131136.

100. Lehmann JM, McKee DD, Watson MA, Willson TM, Moore JT, Kliewer SA. The human orphan nuclear receptor PXR is activated by compounds that regulate CYP3A4 gene expression and cause drug interactions. J.Clin.Invest 1998; 102:1016-1023.

101. Bertilsson G, Heidrich J, Svensson K, Asman M, Jendeberg L, Sydow-Backman $\mathrm{M}$, Ohlsson R, Postlind H, Blomquist P, Berkenstam A. Identification of a human nuclear receptor defines a new signaling pathway for CYP3A induction.

Proc.Natl.Acad.Sci.U.S.A 1998; 95:12208-12213.

102. Williams JA, Ring BJ, Cantrell VE, Jones DR, Eckstein J, Ruterbories K, Hamman MA, Hall SD, Wrighton SA. Comparative Metabolic Capabilities of CYP3A4, CYP3A5, and CYP3A7. Drug Metab Dispos. 2002; 30:883-891.

103. Asghar A, Gorski JC, Haehner-Daniels B, Hall SD. Induction of multidrug resistance-1 and cytochrome P450 mRNAs in human mononuclear cells by rifampin. Drug Metab Dispos. 2002; 30:20-26.

104. Kuehl P, Zhang J, Lin Y, Lamba J, Assem M, Schuetz J, Watkins PB, Daly A, Wrighton SA, Hall SD, Maurel P, Relling M, Brimer C, Yasuda K, 
Venkataramanan R, Strom S, Thummel K, Boguski MS, Schuetz E. Sequence diversity in CYP3A promoters and characterization of the genetic basis of polymorphic CYP3A5 expression. Nat.Genet. 2001; 27:383-391.

105. Fuzzati N, Gabetta B, Strepponi I, Villa F. High-performance liquid chromatography-electrospray ionization mass spectrometry and multiple mass spectrometry studies of hyperforin degradation products. J.Chromatogr.A 2001; 926:187-198.

106. Fu Y, Sheu C, Fujita T, Foote CS. Photooxidation of troglitazone, a new antidiabetic drug. Photochem.Photobiol. 1996; 63:615-620.

107. Luo G, Cunningham M, Kim S, Burn T, Lin J, Sinz M, Hamilton G, Rizzo C, Jolley S, Gilbert D, Downey A, Mudra D, Graham R, Carroll K, Xie J, Madan A, Parkinson A, Christ D, Selling B, LeCluyse E, Gan LS. CYP3A4 Induction by Drugs: Correlation between a Pregnane X Receptor Reporter Gene Assay and CYP3A4 Expression in Human Hepatocytes. Drug Metab Dispos. 2002; 30:795804. 